\title{
SOEP
}

SOEPpapers
on Multidiscoplinary Panel Data Research

SOEPDaNoers
on Multidisciplinary Panel Data Research

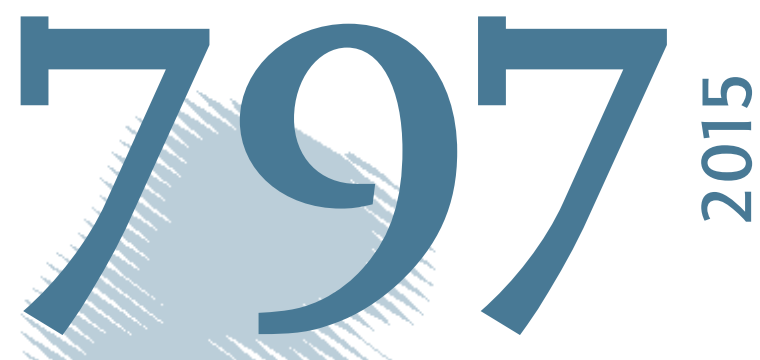

\section{Accounting for the Spouse when Measuring Inequality of Opportunity}

Andreas Peichl and Martin Ungerer 
This series presents research findings based either directly on data from the German SocioEconomic Panel study (SOEP) or using SOEP data as part of an internationally comparable data set (e.g. CNEF, ECHP, LIS, LWS, CHER/PACO). SOEP is a truly multidisciplinary household panel study covering a wide range of social and behavioral sciences: economics, sociology, psychology, survey methodology, econometrics and applied statistics, educational science, political science, public health, behavioral genetics, demography, geography, and sport science.

The decision to publish a submission in SOEPpapers is made by a board of editors chosen by the DIW Berlin to represent the wide range of disciplines covered by SOEP. There is no external referee process and papers are either accepted or rejected without revision. Papers appear in this series as works in progress and may also appear elsewhere. They often represent preliminary studies and are circulated to encourage discussion. Citation of such a paper should account for its provisional character. A revised version may be requested from the author directly.

Any opinions expressed in this series are those of the author(s) and not those of DIW Berlin. Research disseminated by DIW Berlin may include views on public policy issues, but the institute itself takes no institutional policy positions.

The SOEPpapers are available at

http://www.diw.de/soeppapers

\section{Editors:}

Jan Goebel (Spatial Economics)

Martin Kroh (Political Science, Survey Methodology)

Carsten Schröder (Public Economics)

Jürgen Schupp (Sociology)

Conchita D'Ambrosio (Public Economics)

Denis Gerstorf (Psychology, DIW Research Director)

Elke Holst (Gender Studies, DIW Research Director)

Frauke Kreuter (Survey Methodology, DIW Research Fellow)

Frieder R. Lang (Psychology, DIW Research Fellow)

Jörg-Peter Schräpler (Survey Methodology, DIW Research Fellow)

Thomas Siedler (Empirical Economics)

C. Katharina Spieß (Education and Family Economics)

Gert G. Wagner (Social Sciences)

ISSN: 1864-6689 (online)

German Socio-Economic Panel (SOEP)

DIW Berlin

Mohrenstrasse 58

10117 Berlin, Germany

Contact: Uta Rahmann | soeppapers@diw.de

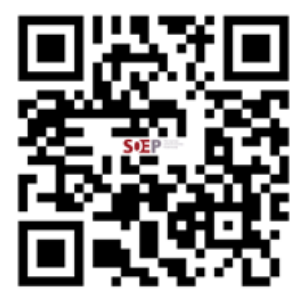




\title{
Accounting for the Spouse \\ when Measuring Inequality of Opportunity
}

\author{
Andreas Peichl and Martin Ungerer \\ October $12,2015^{*}$
}

\begin{abstract}
Existing literature on inequality of opportunity (IOp) has failed to address the question as to how the circumstances and choices of spouses in a couple should be treated. By omitting information relevant to the spouse in IOp estimations, the implicit assumption was full responsibility for the partner's income, effort and circumstance variables. In this paper, we discuss whether or not the partner's characteristics should be treated as responsibility factors. Using German micro data, we analyze empirically, how IOp estimates are affected when a partner's circumstance or effort variables are included as own circumstances in the analysis. Our analysis indicates that including spouse's variables can increase IOp measures by more than 20 (35) percent for gross (net) earnings. The less the responsibility assumed for the partner's variables, the higher the IOp estimate.
\end{abstract}

JEL Codes: D63, H2, J62, J7

Keywords: Equality of Opportunity; Earnings Inequality; Couple; Family Background; Assortative Mating

* Andreas Peichl (peichlezew.de) is affiliated to ZEW, University of Mannheim, IZA and CESifo. Martin Ungerer (ungererezew.de) is affiliated to ZEW and University of Cologne. We are grateful to Marc Fleurbaey, Dirk Neumann, Nico Pestel and participants at the Canazei Winter School and in Mannheim for many valuable comments and suggestions. Corresponding author: Andreas Peichl, ZEW Mannheim, L7, 1, 68161 Mannheim, Germany. 


\section{Introduction}

The concept of equality of opportunity (EOp) has received considerable attention since the seminal contributions of Roemer (1993, 1998), Van de gaer (1993) and Fleurbaey (1995) The EOp literature is interested in the sources of inequality, distinguishing between exogenous circumstances and (partially) endogenous effort. Circumstances are defined as all factors beyond the sphere of individual control, such as parental background or gender, for which society deems that individuals should not be held responsible. Conversely, effort refers to all factors for which individuals are held responsible because they (partly) control or choose them, e.g. decisions concerning schooling or labor supply. Inequalities due to circumstances call for compensation whilst society considers inequalities due to effort to be legitimate. All previous studies of inequality of opportunity (IOp) have exclusively analyzed the impact of individual circumstances and choices. A factor which has not yet been studied in the literature is the relation between the personal characteristics of spouses in couples and IOp.2 ${ }^{2}$ By omitting information for the spouse in IOp estimations, the implicit assumption in previous studies was full responsibility for the partner's income, effort and circumstance variables. In this paper, we discuss whether or not the partner's characteristics should be treated as responsibility factors and empirically investigate the impact on IOp estimates of explicitly incorporating the spouse's characteristics in the analysis.

Undertaking this exercise is no trivial task, at least from a philosophical point of view. An open question in the EOp literature is whether an individual is responsible for the choices of his or her partner. According to EOp theory, individuals are not responsible for their own circumstances but only for their effort variables. The same is true for the spouse; he or she is not responsible for his or her circumstances but only for his or her choices. Choosing a partner, however, is a choice. Given that a partner's circumstances are (usually) known when making the mating decision, one could argue that one should be held responsible for one's spouse's circumstances. In fact, due to the omission of spouse's variables from the analysis, this is the implicit assumption in the existing literature. However, this could be at odds with the basic EOp notion that society deems that individuals should not be held responsible for all factors beyond the sphere of individual control. In other words, one could question whether it is acceptable to hold someone responsible for his or her spouse's circumstance characteristics even where the spouse himself is not held accountable for the same characteristics. For

\footnotetext{
${ }^{1}$ See, e.g., Ramos and Van de gaer (2012), Roemer and Trannoy (2015) or Ferreira and Peragine (2015) for recent surveys.

${ }^{2}$ In contrast, studies on inequality within couples look at inequality of outcomes rather than IOp. For instance, Lise and Seitz (2011) show that standard measures of inequality in terms of consumption are underestimated by about 50 percent, if one neglects intra-household inequality. For a survey, see e.g., Browning et al. (2013).
} 
effort variables, it becomes even more tricky. The key question here is how choices are made within couples: Do spouses make joint decisions (unitary household model) or is it rather the case that spouses bargain between their individual choices (collective household model)? In the former case, one could be (more) responsible for one's spouse's choices than in the latter case. We discuss these philosophical questions in further detail below and present four alternative scenarios demonstrating how a spouse's characteristics might be handled. Choosing among these four scenarios will entail a distinct normative choice. We empirically analyze whether, and to what extent, this choice matters for IOp estimates.

As mentioned above, by looking only at one's own circumstances, the implicit assumption in the literature produced thus far, has been full responsibility for partner's variables independent on whether they are circumstances or effort. In the empirical part of this paper, we use German micro data in order to investigate the extent to which relaxing this assumption will result in changes in IOp estimates. Our results show that including spouses' variables increases IOp measures by more than 20 (35) percent for gross (net) earnings. The less the responsibility assumed for the partner's variables, the higher the IOp estimate. Our findings therefore suggest that deciding whether and how to account for spouses' outcomes in couples, is of considerable importance for IOp estimates. Assuming full responsibility, the current practice in the literature, might thus result in underestimation of IOp.$^{3}$ We show that at least part of this effect originates from assortative mating, suggesting that sorting into couples cannot be ignored when measuring IOp.

This paper is organized as follows: In section 2, we introduce the conceptual framework of IOp and couples. Section 3 describes the data. Section 4 presents the results of our empirical analysis. Section 5 concludes.

\section{Conceptual Framework and Methodology}

\subsection{Measuring IOp: a simple model}

In order to compare our results to previous IOp estimates, we follow standard practice to define our theoretical and empirical approaches. $4^{4}$ In accordance with Roemer (1998), we distinguish between two generic determinants of outcome $y_{i}$ of individual $i$. First, circumstances $C_{i}$ are characteristics which are beyond individual control (consider race, gender, family background) and which are therefore a source of illegitimate inequali-

\footnotetext{
${ }^{3}$ This is even more problematic when estimating IOp for societies where marriages are arranged (e.g., by parents) and where partners themselves have a limited say in who they marry.

${ }^{4}$ The notation closely follows Niehues and Peichl (2014).
} 
ties in outcomes. Second, effort $E_{i}$ represents all factors affecting earnings which are assumed to be the result of personal responsibility $!^{5}$ We focus on annual labor earnings $w_{i}$ which is generated by some function $f$ of $C_{i}$ and $E_{i}$, which itself might depend on $C_{i}: E_{i}=E_{i}\left(C_{i}\right)$.

$$
w_{i}=f\left(C_{i}, E_{i}\left(C_{i}\right)\right)
$$

Following Ferreira and Gignoux (2011) and Niehues and Peichl (2014), we employ the ex-ante approach of EOp (Fleurbaey and Peragine 2013) by partitioning the population of agents $i \in\{1, \ldots N\}$ into a set of disjunct types $\Pi=\left\{T_{1}, T_{2}, \ldots T_{k}\right\}$, i.e. subgroups of the population which are homogeneous in terms of their circumstances. The income distribution within a given type is a representation of the opportunity set which can be achieved for individuals with the same circumstances $C_{i}$ by exerting different degrees of effort. Perfect EOp is achieved if the mean advantage levels $\mu$ are identical across these types, i.e., $\mu^{k}(w)=\mu^{l}(w), \forall l, k \mid T_{k}, T_{l} \in \Pi$. In our case, this corresponds to identical mean wages across types. Measuring IOp thus means capturing the extent to which $\mu^{k}(w) \neq \mu^{l}(w)$, for $k \neq l$. To compute a measure of IOp, Checchi and Peragine (2010) suggest constructing a hypothetical smoothed distribution (Foster and Shneyerov 2000), $\mu^{k}(w)$, which is obtained when each individual outcome, $w_{i}^{k}$, is replaced by the group-specific mean for each type, $\mu^{k}(w)$.

Based on this smoothed distribution, we calculate for any (scale invariant) inequality index $I$, the absolute inequality of opportunity level (IOL) $\theta_{a}=I\left(\left\{\mu_{i}^{k}\right\}\right)$. While the whole idea of opportunity egalitarianism is to look at IOp and not at total inequality in outcomes, it might still be informative to look at the relative share of total inequality that can be attributed to circumstances, i.e. the inequality of opportunity ratio (IOR) $\theta_{r}=\frac{I\left(\left\{\mu_{i}^{k}\right\}\right)}{I(w)}$. This approach allows the total income inequality to be decomposed into inequality within types (i.e. effort inequality) and inequality between types (i.e. opportunity inequality). Due to data limitations, we restrict our analysis to between type inequality since cell sizes of types tend to become smaller with increasing numbers of regressors. In order to respect the axioms of anonymity, Pigou-Dalton transfer principle, normalization, population replication, scale invariance and subgroup decomposability, we choose a member of the Generalized Entropy class (Shorrocks 1980) as an inequality measure. By introducing the further requirement of path-independent decomposability (see Foster and Shneyerov (2000)), the set of eligible indices reduces

\footnotetext{
${ }^{5} \mathrm{As}$ is common in the majority of EOp literature, we do not explicitly take into account the role of luck in our estimations. Hence, we (implicitly) assume that luck belongs to the sphere of individual responsibility and in our deterministic model, the individual is held responsible for any random component that may affect his income and that cannot be attributed to the observed circumstances. The same is true for potential measurement errors in the earnings data. See Lefranc et al. (2009) for the extension of the EOp framework in order that it explicitly take luck into account.
} 
to the mean $\log$ deviation (MLD) $I_{0}=\frac{1}{N} \sum_{i} \ln \frac{\mu_{w}}{w_{i}}$.

\subsection{Responsibility for the mating choice?}

The basic notion of EOp is that nobody should be held responsible for circumstances beyond the sphere of individual control. An open question in the EOp literature is, however, whether an individual in a relationship is responsible for his or her partner. So far, the EOp literature does not explicitly make these considerations, i.e. in empirical applications only own circumstances are included. Therefore, the current baseline case is full responsibility for the partner's effort and circumstance variables as these variables are implicitly treated as (unobserved) effort (henceforth labeled as (i) Full responsibility). We use this case as a benchmark in order to compare various possible scenarios which differ in terms of responsibility of the partner's income, effort and circumstance variables. The baseline case of full responsibility for all variables can be rationalized as follows. Individuals are not responsible for their own circumstances but only for their own effort variables. The same is true for the spouse. He or she is not responsible for his or her circumstances but only for his or her choices. Choosing a partner, however, is a choice. A partner's circumstances are (usually) known when committing to a relationship and are therefore an individual choice in the sense that individuals are fully aware of the set of per-determined circumstances the partner has. One can also argue that an individual is responsible, not only for the spouse's circumstances, but also for the spouse's choices. This is the case in an unitary household model where both partners jointly decide on labor supply and effort, and hence income (Chiappori and Meghir 2014).

However, it is well documented that wage setting institutions as well as potential wage discrimination are important determinants of individual earnings. While these factors might be known to the individual, there is little he or she can do about it. Hence, one can argue that individuals should not be held responsible for the partner's wage earnings ${ }^{6}$ Given, however, that circumstances are known and, in a unitary model, both partners will reach a joint decision regarding effort, one could be held responsible for these factors. We therefore define the second scenario as responsibility for the partner's circumstances and choices, but not the partner's wage ((ii) Responsible only for partner's circumstances and effort (unitary model)).

The unitary model of joint decision on labor supply and effort in a household is one possibility. In the collective household model, however, both partners individually exert effort in terms of labor market activity before bargaining about the distribution of joint

\footnotetext{
${ }^{6}$ To be precise, the individual should not be held responsible for the residual earnings of the partner conditional on the partner's circumstance and effort variables.
} 
household income. In such a framework, the effort variables of the partner are not the choice of the individual, rather they are determined solely by the spouse, possibly after committing to a relation. The third scenario is therefore the responsibility for partner's circumstances, but not for his or her income and choices (effort) ((iii) Responsible only for partner's circumstances (collective model)).

Finally, one can argue that nobody should be held responsible for any circumstances, choices or the income of their partner. There are two arguments which might support this scenario. First, the notion of IOp is that nobody should be held responsible for things beyond the sphere of individual control. As we cannot control the circumstances of our partner, except by leaving him or her or by refusing to mate, a partner's circumstances can actually not be considered as an own choice as such $]^{7}$ Second, the choice set of available partners is not necessarily identical for all individuals. One observation of the existing literature on couples and family economics is the phenomenon of increased assortative mating. Hence, higher educated individuals increasingly mate with other highly educated (Schwartz and Mare 2005). While highlyskilled individuals may choose from a pool of low- and highly-skilled partners, potential partners of low-skilled individuals are mostly limited to other low skilled. This leaves high and low skilled individuals with different choice sets. Combining both arguments, our fourth scenario is no responsibility whatsoever for the partner's characteristics at all ((iv) No responsibility).

\subsection{Empirical strategy to estimate IOp}

\subsubsection{Baseline case}

In our empirical estimation approach, we use the same parametric specification as Niehues and Peichl (2014) to estimate IOp. 8 Relying on a parametric approach allows us to estimate the impact of numerous circumstance variables even in the presence of small sample and cell sizes. $9^{9} \log$-linearization of equation (1) and adding an error term

\footnotetext{
${ }^{7}$ In addition, one might not be fully aware of a partner's full set of circumstances due to asymmetric information when committing to a relationship.

${ }^{8}$ In empirical estimations of EOp, it is impossible to observe all characteristics that constitute an individual's circumstances (e.g. innate talent or ability). Hence, existing estimates of IOp are only lower bound estimates of the true share of unfair inequalities due to circumstances (Ferreira and Gignoux 2011). Exceptions are Bourguignon et al. (2007) who simulate the magnitude of omitted variable bias to estimate bounds around the true effect of observed circumstances on income inequality and Niehues and Peichl (2014) who suggest an upper bound estimator.

${ }^{9}$ In contrast, non-parametric methods avoid the arbitrary choice of a functional form on the relationship between outcome, circumstances and effort (e.g. Lefranc et al. (2008), Ferreira and Gignoux (2011) or Aaberge et al. (2011)). However, this approach has the drawback that considering more than one circumstance variable is difficult due to practical reasons in the presence of small cell sizes which is usually the case in survey data. Access to large-scale administrative panel data with information on circumstances (family background), which is not available in Germany, would allow to
} 
yields the following empirical specifications:

$$
\begin{aligned}
\ln w_{i} & =\alpha C_{i}+\beta E_{i}+u_{i}, \\
E_{i} & =\kappa C_{i}+v_{i} .
\end{aligned}
$$

Equation (2) represents the direct effect of circumstances on income while equation (3) models the indirect effect of circumstances on income through effort. Since it is unlikely that we will observe all relevant circumstance and effort variables that shape individuals' outcomes, estimating this model will likely yield biased estimates. However, in order to compute IOp shares, it is not necessary to estimate the structural model and to derive causal relationships. By substituting the effort equation (3) into the earnings equation (2), we obtain the following reduced-form relationship:

$$
\ln w_{i}=\underbrace{(\alpha+\beta \kappa)}_{\psi} C_{i}+\underbrace{\beta v_{i}+u_{i}}_{\eta_{i}} .
$$

This equation can be estimated by OLS to derive the fraction of variance which is explained by circumstances. If all observed circumstances, $C^{K}$, are included in the equation (4), then the estimate $\widehat{\psi}$ measures the overall effect of circumstances on labor earnings, combining both the direct and indirect effects. On this basis, we can construct a parametric estimate of the smoothed distribution:

$$
\widetilde{\mu}^{L B}=\exp \left[\widehat{\psi} C_{i}^{K}+\sigma^{2} / 2\right]
$$

As we replace earnings by their predictions (with $\sigma^{2}$ being the estimated residual variance in the earnings equation, see Blackburn (2007)), all individuals with the same circumstances necessarily have the same advantage levels. Thus, in the case of absolute EOp, i.e. no income differences due to (observed) circumstances $C_{i}^{K}$, all predicted earning levels would be identical. IOp can subsequently be measured as the inequality of these counterfactual earnings levels, where differences are only due to differences in circumstances.

\subsubsection{Spouses and IOp}

We analyze the impact of partners personal characteristics on IOp by extending the baseline measure in three steps. The current approach in the literature (according to equation (4)) implicitly assumes full responsibility for the partner's variables as these are not included as circumstances in the regression and are hence treated as unobserved effort. This baseline case serves as a benchmark for further specifications (ii) - (iv). The estimate IOp also non-parametrically. 
second case assumes responsibility for the partner's circumstances and effort variables ((ii) Responsible only for partners' circumstances and effort (unitary model)). This is empirically implemented by adding the earnings of the partner, $\ln w_{i}^{P}$, to equation (4), treating them as circumstances of the individual:

$$
\ln w_{i}=\psi C_{i}+\zeta \ln w_{i}^{P}+\eta_{i}
$$

The definition of the third scenario ((iii) Responsible only for partner's circumstances (collective model)) proceeds analogously. In order to hold the individual responsible for the circumstance variables of the partner, one adds the earnings and effort $\left(E_{i}^{P}\right)$ variables of the spouse to the wage regression (4):

$$
\ln w_{i}=\psi C_{i}+\zeta \ln w_{i}^{P}+\lambda E_{i}^{P}+\eta_{i}
$$

Finally, the case of full responsibility adds all income, effort and circumstance $\left(C_{i}^{P}\right)$ variables of the partner to the wage equation ( $(i v)$ No responsibility). In this case, the partner is fully accounted for in the wage regression. Hence, all of his or her personal characteristics are treated as circumstances of the individual:

$$
\ln w_{i}=\psi C_{i}+\zeta \ln w_{i}^{P}+\lambda E_{i}^{P}+\phi C_{i}^{P}+\eta_{i}
$$

To sum up, while in equation (44) all partner variables are (implicitly) treated as effort, this changes in the following equations. In the end, in equation (8), all partner variables are treated as own circumstances. Hence, comparing equations (4) with (6) - (8) gives the full range of no to maximal impact of accounting for the partner in IOp estimations.

\section{Data}

For our estimations, we use the latest version of the German Socio-Economic Panel $(\mathrm{SOEP})$ The SOEP is a representative panel study of households and individuals in Germany 11 For our analysis, we use information from 1992 until 2012, i.e. the the period following the German reunification.

In line with the previous literature and especially following Niehues and Peichl (2014), the units of our analysis are individuals aged 25-55 with data on parental background. We exclude singles from our analysis since we are interested in the relation between partners' characteristics in couples. The dependent variables are log real (gross

\footnotetext{
${ }^{10}$ Socio-Economic Panel (SOEP) (2013)

${ }^{11} \mathrm{~A}$ detailed overview of the SOEP is provided by Haisken De-New and Frick (2003) and Wagner et al. (2007). Issues concerning sampling and weighting methods or the imputation of information in case of item or unit non-response is well documented by the SOEP Service Group.
} 
or net) labor earnings, adjusted by consumer prices indices. Inequality measures are based on the corresponding absolute levels of earnings.

As circumstance variables, we include gender, the year of birth of the individual, dummies for whether the individual was born in a foreign country or in East Germany, the degree of urbanization of the place where the individual was born, categorical variables of the occupation and education of the father as well as the height of the individual. Summary statistics on the mean annual earnings and all circumstance variables are reported in table A.1 in the appendix. The effort variables used in the different specifications are work experience, working hours, education, and industry.

\section{Empirical results}

\subsection{Estimation of earnings equations}

We begin our analysis by regressing the log earnings for each year on all available circumstance variables which are expected to have an impact on labor earnings (equation 4). The results for the baseline scenario as well as the case of no responsibility in gross and net annual earnings are reported in tables A.3 - A.10 in the appendix. Using the baseline case $(i)$, we can identify the well-known gender wage gap in gross and net wages. Although the gender pay gap is gradually declining over time, women continue to have significantly lower wages in comparison to male colleagues. Being an immigrant or being born in Eastern Germany has a negative impact on wages. Individuals with highly educated fathers or parents working as civil servants have higher wages compared to blue-collar workers or self-employed parents. Being born in larger cities, as opposed to the countryside, is also associated with higher wages. The educational degree of the father has a strong but ambiguous effect.

Controlling for the partner's income in equation (6) yields the case of responsibility for partner's circumstance and effort variables $(i i)$. The income of the partner has a significant negative effect on personal earnings. At a first glance, this seems to contradict previous findings of increased assortative mating. However, our analysis is carried out in terms of annual earnings. As we have a part time work quota of about 40 percent for females and only 5 percent for men, the observed negative correlation is less surprising. In addition, we find a positive correlation for hourly wages. Comparing gross and net figures, we find systematically higher coefficients for net earnings. This indicates a possible effect of the German system of joint income taxation.

Controlling for effort and income variables of the partner, we assume responsibility only for partner's circumstances (iii), as implemented in equation (7). A higher level of education on the part of the partner is associated with higher earnings of the indi- 
vidual. The coefficient increases over time and has significant since 1994. In line with the literature on assortative mating, we find a positive correlation between spouses' education. The industry in which the partner works has no clear effect on individual earnings. Figures for gross and net earnings show similar results for this specification.

The specification of no responsibility for the partner $(i v)$ is implemented by controlling for all available partner information in equation (8). The partner's circumstance variables show different patterns compared to the individual's own variables. A higher educational degree of the father has a negative effect from 1991 until 1999, with significant values only in 1998 and 1999. Since then, the degree of the father has had only a small negative and insignificant effect on earnings and even turned positive since 2001 . Having a foreign partner or a partner from East Germany has no significant effect on individual earnings. If the partner has a father working as a professional, e.g. as a high skilled manager, it is associated with higher earnings, while an occupation in agriculture corresponds to lower earnings.

\subsection{Inequality levels}

Outcome inequality. Inequality for gross and net earnings measured by mean log deviation (MLD) is depicted in figure 1 and shows a generally increasing trend for both, gross and net earnings. Starting in 1991, inequality in terms of MLD is increasing from 0.28 to 0.36 in 2011. The strongest increases are found between 1991/1992 and $2006 / 2007$ with increases of 0.036 and 0.039 points, respectively. Inequality in gross earnings is significantly larger compared to net earnings. Here, MLD increases from 0.26 in 1991 to 0.32 in 2011.

Figure 1: MLD for annual income - gross vs. net

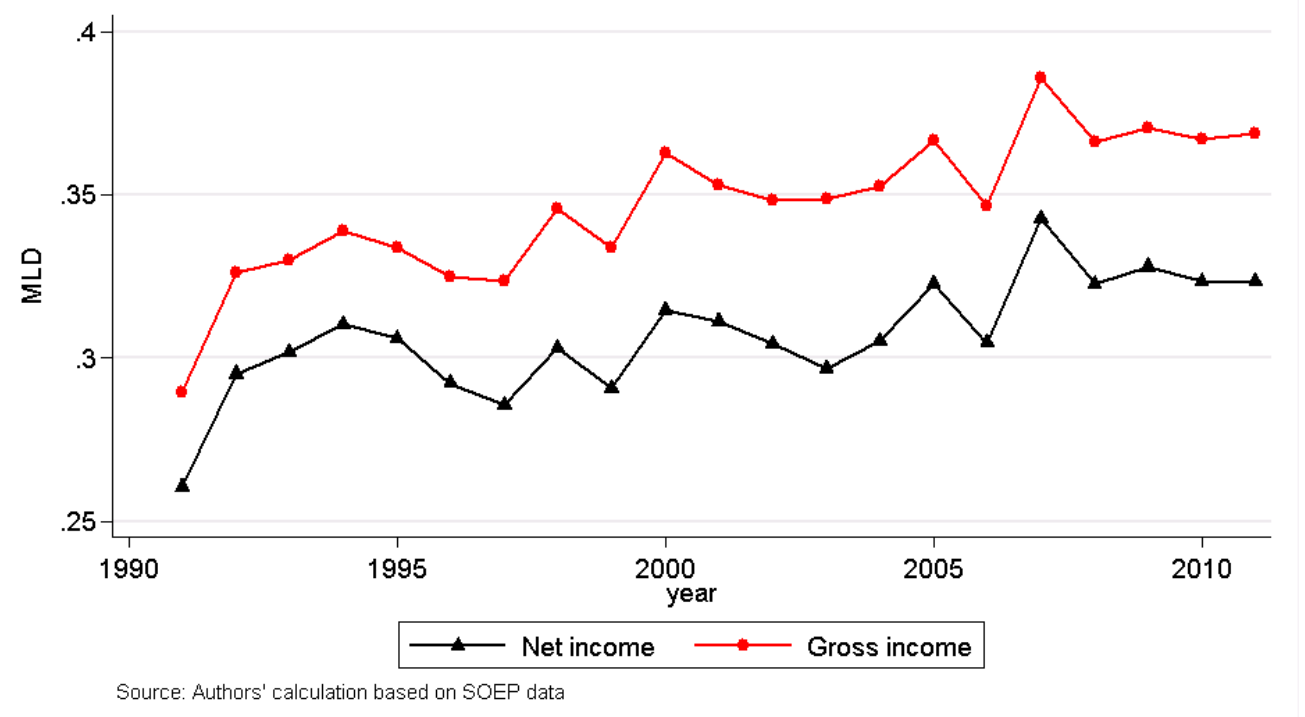


Comparing male and female gross earnings in figure 2, we find higher inequality among female earners. However, while MLD for men is steadily increasing, it shows an inverse U-shaped pattern for women. The MLD for men increases from 0.12 in 1991 to 0.24 in 2011. Values for the female sample are 0.30 in 1991 and 0.33 in 2011, with a peak of 0.41 in 2004 . Using net instead of gross earnings for the comparison of the male and female sub-samples, we find similar trends. The values in this case are, however, generally lower, as inequality in net earnings is lower than that relative to gross earnings.

Figure 2: MLD for annual income - male vs. female
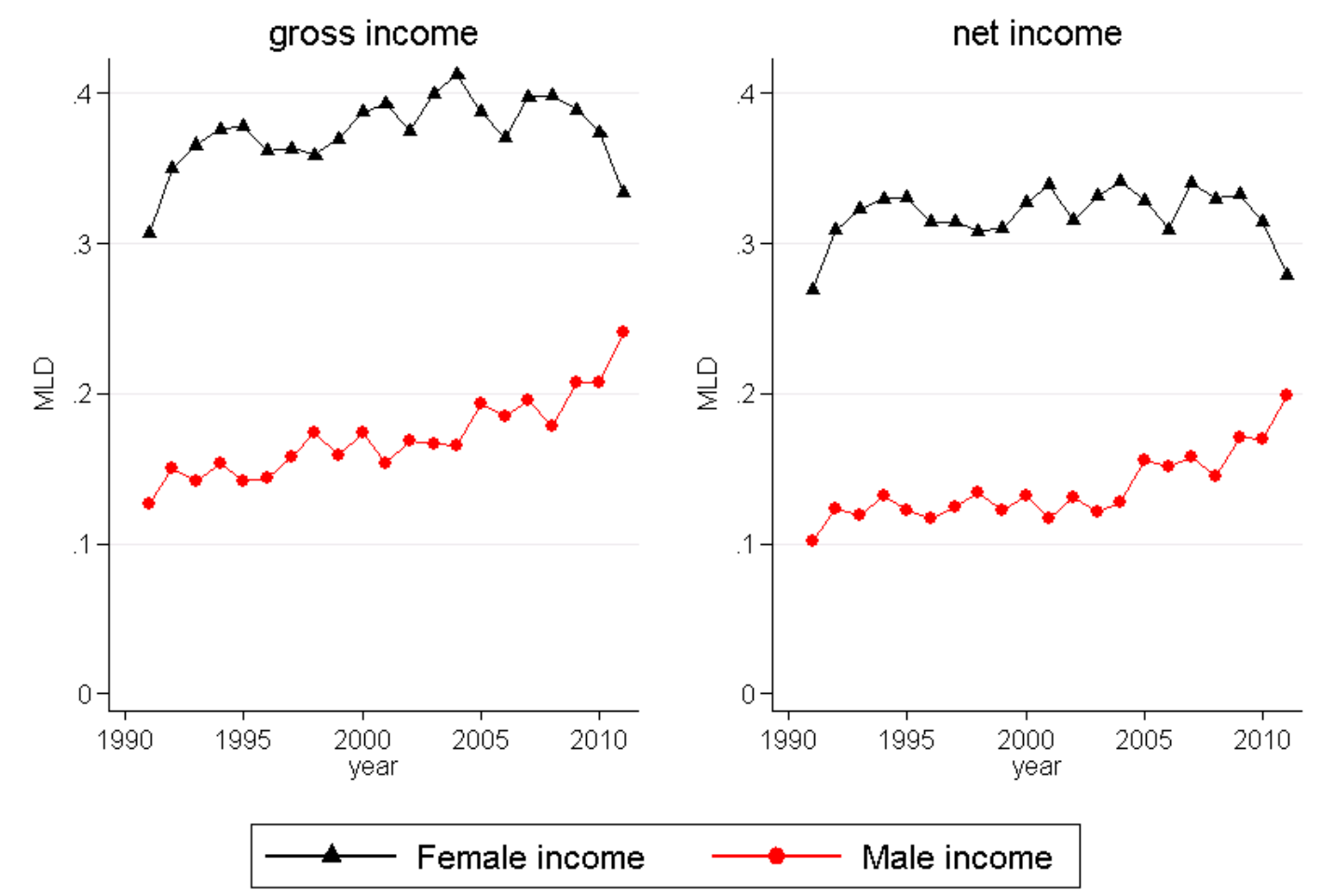

Source: Authors' calculation based on SOEP data

Inequality of opportunity. The lower bound level of inequality of opportunity (IOL) is estimated by computing the MLD of the predicted values from the earnings equation. We do this for specifications (4), (6) - (8) using gross and net annual earnings. In addition, we distinguish between male and female individuals. The results for gross and net earnings are shown in figure 3 . The black line displays the baseline case from equation (4). The red line corresponds to the model including partner's circumstance variables shown by equation (6). The case of the model from equation (7), including both the partner's circumstance and effort variables, is displayed by the blue line. Finally, the full specification including circumstances, effort and income variables of 
the partner corresponds to the yellow graph (equation (8)).

Figure 3: IOL for annual income - gross vs. net
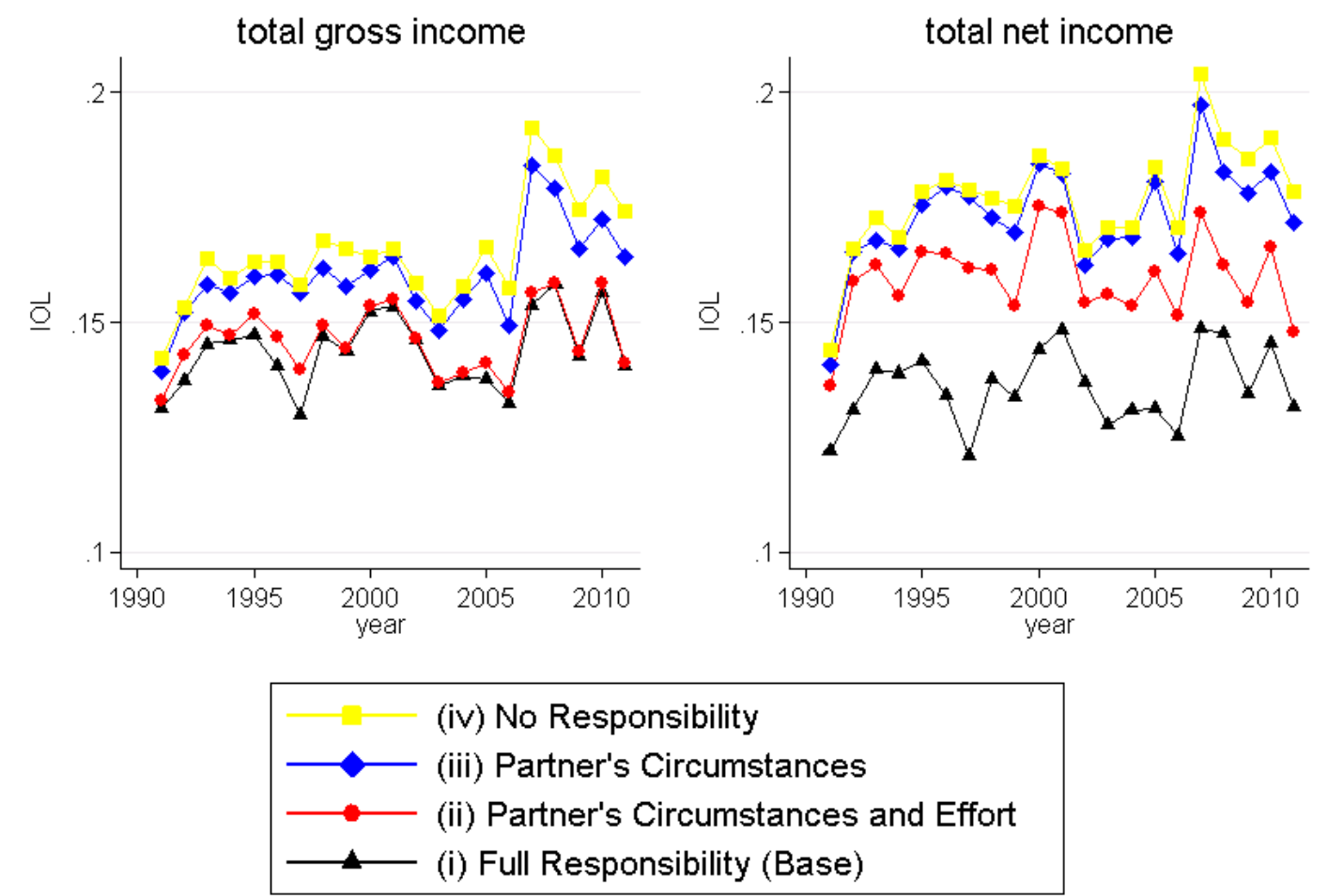

Source: Authors' calculation based on SOEP data

For the baseline case, the inequality of opportunity level is lower for net earnings than for gross earnings. Aside from this, the figures for IOL in net earnings are slightly higher. Regardless of the specification, IOL shows a slightly increasing trend, with a jump between 2006 and 2007. In terms of gross income, controlling for the partner's income (case of responsibility for partner's circumstances and effort, displayed by the red graph) does not increase IOL. Using net earnings instead, we find a significant increase in explanatory power and hence also in IOL when controlling for the income of the partner. This indicates that it is an effect of the German tax system, as is already visible from the earnings regression. The effect, however, declines over time, visualized on the graph by the narrowing gap between the red and black lines. This may be due to the changing relation of spouses' incomes. We indeed find a negative, but in absolute terms decreasing, correlation between partners' incomes ${ }^{12}$

The case of responsibility for partner's circumstances represented by the blue graph shows mostly identical results for gross and net earnings ${ }^{13}$ Both graphs show an in-

\footnotetext{
${ }^{12}$ The literature on assortative mating shows an increase in assortative mating in education over time that also reflects in earnings (Schwartz and Mare 2005). A detailed discussion on the importance of assortative mating is conducted in 4.4 .

${ }^{13}$ The case of responsibility for partner's circumstances is implemented by controlling for partner's
} 
creased IOL compared to the previous cases. Finally, the case of no responsibility, displayed by the yellow graphs, shows a similar development compared to the previous case. However, since 2005, the circumstance variables of the partner increase in explanatory power.

Figure 4: IOL for annual income - male vs. female net

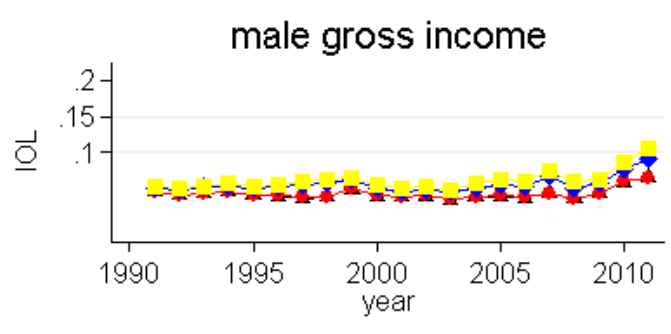

female gross income
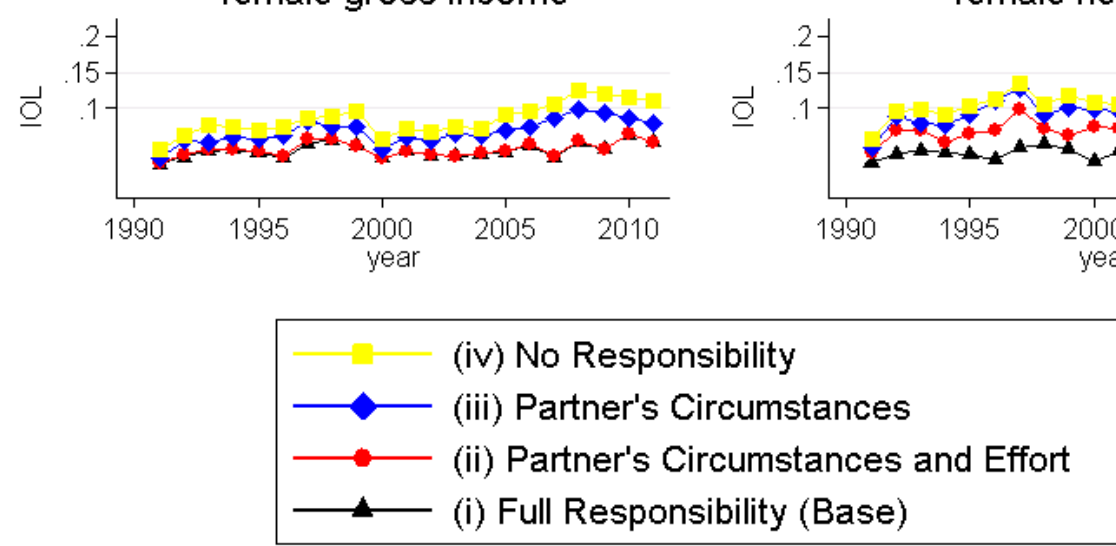

Source: Authors' calculation based on SOEP data

In order to further disentangle the development of IOL, we also consider male and female individuals separately. The results are shown in figure 4 for gross and net earnings as well as for male and female sub-samples. In general, we find that the personal information of the partner has more explanatory power for women than for men, thereby increasing our IOL measures in the different scenarios. Male IOL in gross and net earnings is fairly constant until 2008, with a sharp increase thereafter. For the female sub-sample, we find greater fluctuations over time and also higher IOL for all specifications except the baseline case. In contrast to the development of male IOL, the inequality of opportunity level for women decreases after 2008. When comparing male and female sub-samples in terms of net earnings, the case of responsibility for partner's circumstance (red graph) and effort variables yields interesting results. Controlling for partner's earnings only slightly increases IOL for men, while there is a significantly larger effect for women. However, following a peak in 1997, the divergence between the effort and income variables in equation (7). 
black and red graph diminishes over time. This again indicates an effect of the income tax splitting as well as changing correlation in spouses' earnings.

\subsection{Inequality of opportunity ratios}

Estimating the inequality of opportunity ratio (IOR) is straightforward; we simply divide the IOL by total inequality in annual earnings. We structure our analysis of IOR in a similar way to that of IOL. Starting with the comparison of gross and net annual earnings, we further distinguish between male and female sub-samples. The results for the full sample are shown in figure 5 .

Figure 5: IOR for annual income - gross vs. net
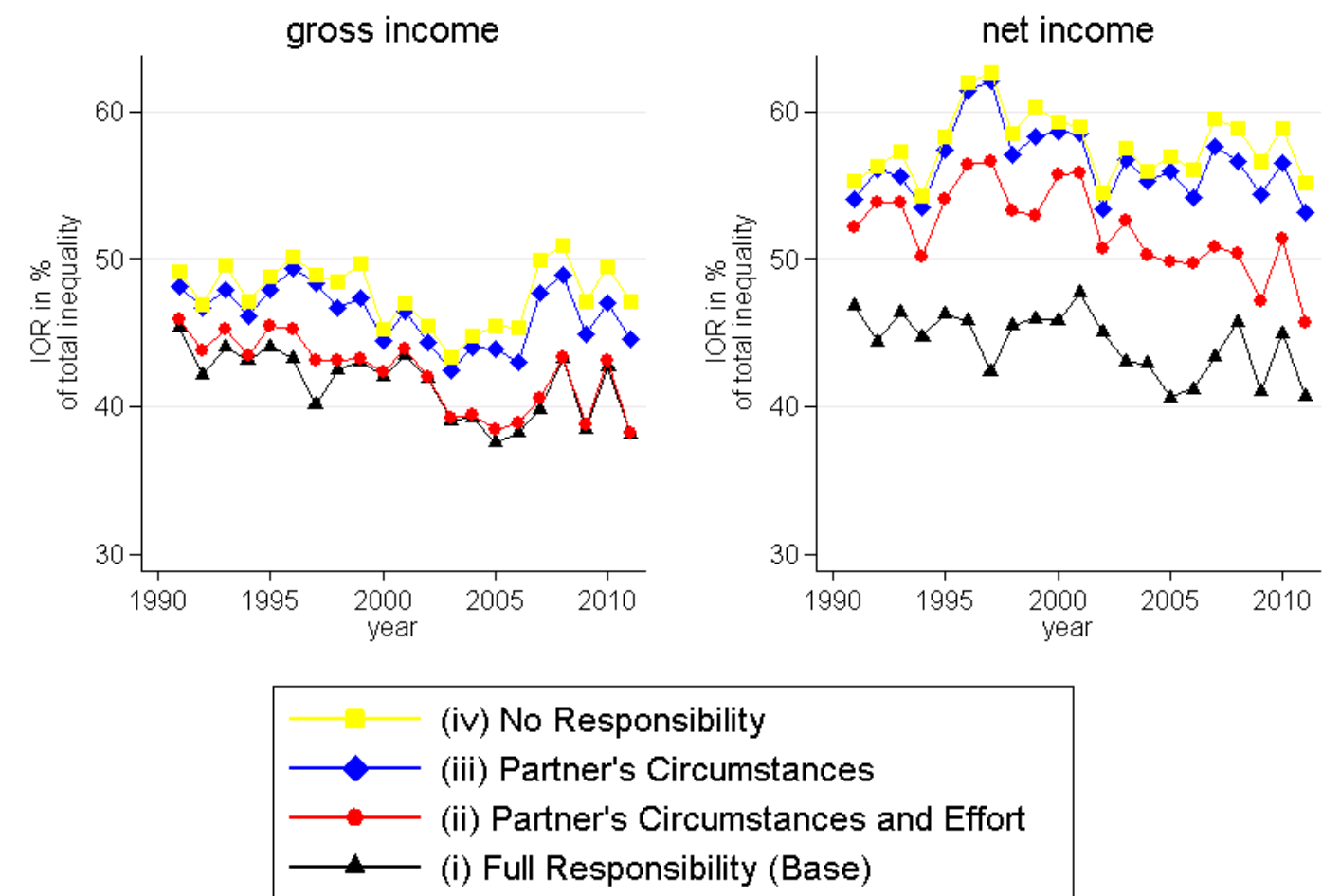

Source: Authors' calculation based on SOEP data

Looking at gross and earnings displayed in figure 5, we find that IOR in gross earnings was decreasing from 1991 until 2005. The majority of the decrease in the IOR can be said to have been driven by the increase in overall earnings inequality rather than decreased IOL. While the baseline case of full responsibility decreases from 45.3 to 37.5 percent, the specification using all available partner information declines from 49.1 percent to 43.3 percent in 2003. Afterwards, we find an increase in IOR up to 50.8 percent in 2008 and strong fluctuations until 2011. Our results show that accounting for partner's variables can be important when measuring IOp, as including 
them increases the lower bound of IOp. While IOR for the baseline case is 38.1 percent in 2011, the full specification yields a value of 47.1 percent. Hence, IOR is 22 percent larger when all information available about the partner is taken into account. The less responsibility is assumed, the higher the IOp measure.

Looking at the baseline case for net earnings, we find a similar development, with slightly higher values. For 1991 and 2001, we find values of 46.8 and 47.7 percent, respectively. Following this, IOR is decreasing until 2005, to 40.6 percent before increasing once again to 45.7 percent in 2008. Since then, we can identify similar fluctuations compared to the case of gross earnings. When the effort and income variables of the partner are included, IOR is fairly constant for net income and on a higher level compared to gross earnings. Using the full specification, IOR has the same value of 55.2 percent in 1991 and in 2011, with an interim peak of 60.2 in 1996. The observation of higher IOR in net earnings than in gross earnings can be explained by the lower overall inequality in net earnings, as IOL remained on a similar level for both, gross and net annual income. Our analysis indicates that including partner variables increases IOp by 8.3 (18.0) percent in 1991 and by 23.7 (35.6) percent in 2011 for gross (net) income. The general trend of decreasing IOR in the baseline case is driven by the increase in earnings inequality rather than be a decrease in IOp.

IOR for gross annual male earnings shows a generally u-shaped pattern over time. This can be seen in figure 6. The baseline case decreases from 36.2 in 1991 to 20.2 percent in 2005. There is a surprising peak of 30.7\% in 1999. Between 2008 and 2011, IOR increased from 20 to 28 percent. We find a similar picture for the other specifications including the spouse's variables, but with higher values. The decrease using the full specification from 1991 to 1998, however, is less marked, declining from 41.9 to 35.8 percent. Only from 2000 to 2009, we find somewhat lower values with 31.1 and 32.9 percent. Thereafter, we once again see an increase to 43.5 percent in 2011.

For the female sub-sample, we find significantly lower initial values for IOR in 1991. The baseline case yields 7 and the full specification 14 percent. IOR increases over time, regardless of the specification used. As was the case for male earnings, there is a drop in IOR between 1999 and 2000. Following this, however, IOR once again increases to 15.6 in 2011 for the baseline case and 32.9 percent for the case of no responsibility.

Comparing male and female IOR for net earnings, the findings are similar to the case of gross earnings, with slightly lower figures. The only difference is in the case of no responsibility. While for men, the income of the spouse only yields limited additional information, IOR for female net earnings increases significantly when the income of the partner is included. IOR is 21.4 in 1991 and increases to 42.5 percent in 1997. IOR decreases to 26.0 in 2002, has a peak in 2008 and then once again decreases again to 36.8 percent in 2011. Adding partner variables to the analysis of gross income increases 
Figure 6: IOR for annual income - male vs. female
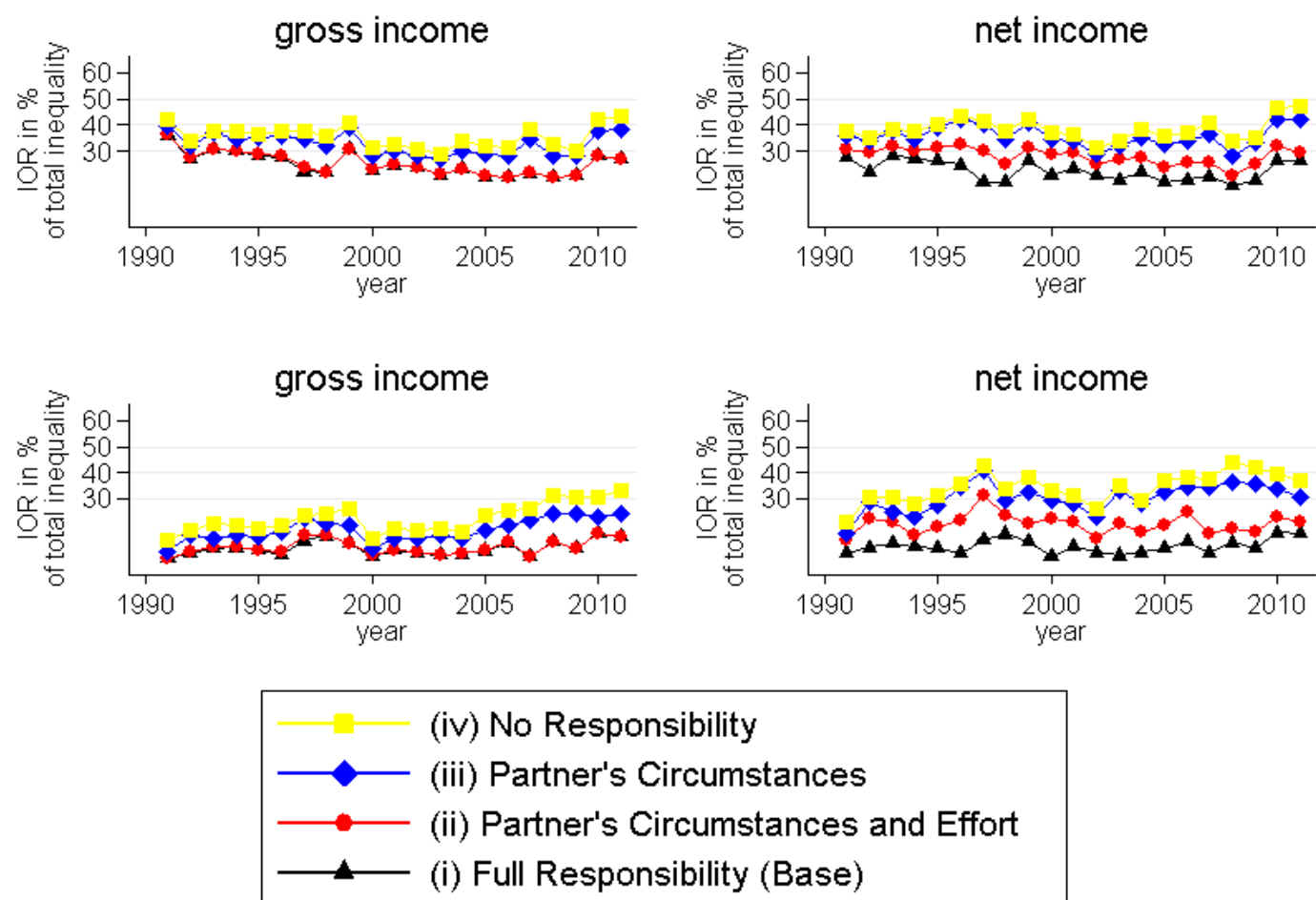

Source: Authors' calculation based on SOEP data

IOp for men by 15.9 (61.1) percent in 1991 (2011) and for women by 91.2 (111) percent in 1991 (2011).

To sum up, it is clear from our findings, that the personal characteristics of the partner play a significant role for IOp. They increase our estimate of the IOR by up to 20 (35) percent for gross (net) earnings. In the next step, we analyze the role of assortative mating for these results.

\subsection{Assortative Mating}

In order to gain initial insight into the extent of assortative mating, we compare correlations of key variables displayed in table 1. We find a negative correlation between spouses' annual earnings. Considering the differences in part-time work between female and male employees, this is not surprising. The negative correlation decreases over time which might stem from a decline of the male breadwinner model as more women tend to work. Looking at hourly wages rather than yearly earnings accounts for the difference in the volume of employment. Here, we find a small but persistent positive correlation in wages. According to the literature (Schwartz and Mare 2005), the main variable to measure assortative mating is education. Considering years of education, a positive correlation is found in all years with a range between 0.549 and 
0.631. Hence, spouses tend to have similar years of education.

Table 1: Correlations of selected variables

\begin{tabular}{rrrr} 
Year & Annual Earnings & Hourly Wages & Education \\
\hline 1992 & -0.396 & 0.080 & 0.561 \\
1994 & -0.368 & 0.131 & 0.605 \\
1996 & -0.475 & 0.061 & 0.572 \\
1998 & -0.395 & 0.119 & 0.567 \\
2000 & -0.391 & 0.032 & 0.569 \\
2002 & -0.355 & 0.140 & 0.563 \\
2004 & -0.322 & 0.070 & 0.577 \\
2006 & -0.338 & 0.067 & 0.549 \\
2008 & -0.277 & 0.072 & 0.593 \\
2010 & -0.283 & 0.076 & 0.558 \\
2011 & -0.225 & 0.168 & 0.631 \\
\hline
\end{tabular}

In order to investigate the role of assortative mating for IOp in couples, we recompute the IOp measures for the 4 different scenarios by randomly re-matching couples (Burtless 1999, Aaberge et al. 2005, Pestel 2014). ${ }^{14}$ We then compare the obtained IOp measures for the re-matched sample to the results for the original sample ${ }^{15}$

The resulting IOp measures are displayed in figure 7. Note that overall inequality does not change due to re-sampling as we do not drop any individuals. With the exception of the baseline case, we find that our measures of IOp are substantially smaller using the sample of re-matched couples. Hence, the personal characteristics of a partner show less correlation with the income of his or her spouse. This is especially true for the scenarios of responsibility for partner's circumstances and no responsibility, as these yield lower estimates of IOR in all years. In the original sample, we found a small but persistent gap, starting in 2005, between these two scenarios. This leads us to conclude that the explanatory power of partners' circumstances has changed. In the rematched sample, however, this gap is fairly constant over time. All in all, we are able to conclude that at least a proportion of our findings that including a spouse's information in the analysis matters for IOp is driven by assortative mating.

\footnotetext{
${ }^{14}$ Note that, by construction, the correlation of spouses' variables in the random couple sample varies around zero.

${ }^{15}$ Note that we abstract from potential behavioral responses (such as labor supply) when facing a new partner with different characteristics (Pestel 2014). Furthermore, we only compare IOp measures in gross earnings as we would have to re-calculate the total tax burden of the new randomly matched couples in order to also analyze IOp in net earnings.
} 
Figure 7: IOR for gross annual income - rematched couples
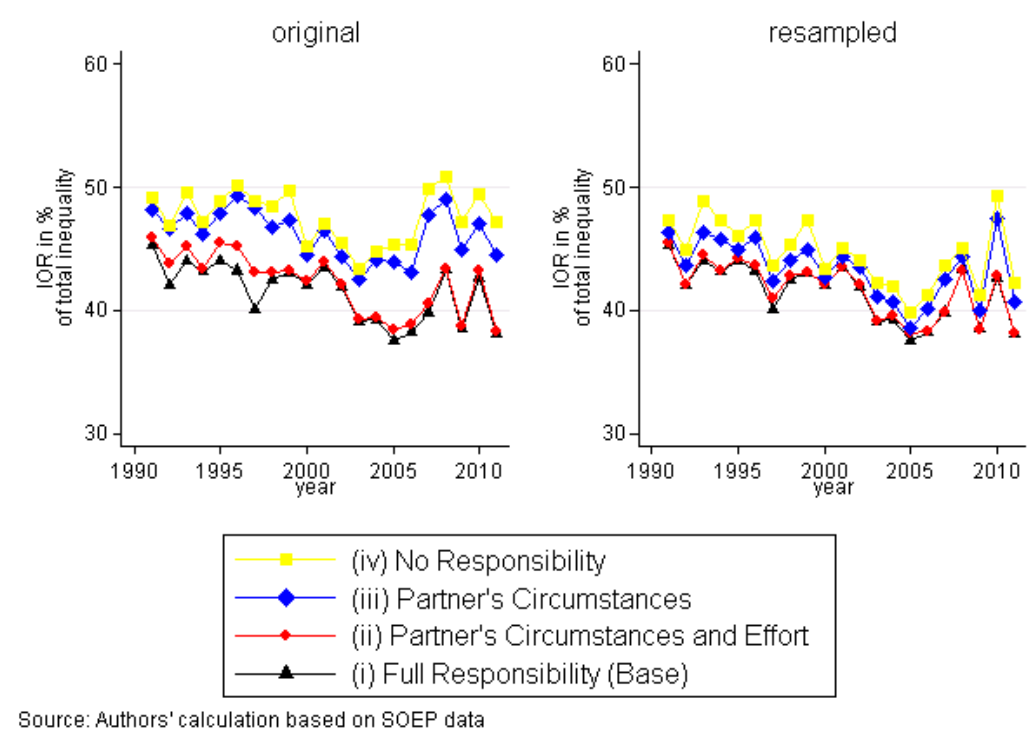

\section{Conclusion}

Thus far, existing literature on IOp has failed to analyze the influence of the partner for IOp of individuals in couples. Using German micro data from 1991 to 2012, we add to the literature by analyzing the effect of a partner's circumstance, effort and earnings variables on individual earnings and hence IOp. The current literature implicitly assumes full responsibility for the partner, as the partner's variables are not accounted for. As the effect of partner's income is declining over time, we suspect that assortative mating is playing a role in this context. The positive correlation between the education level of spouses and a diminishing negative correlation of earnings further emphasize this. Randomly rematching couples shows that IOp measures for our scenarios are substantially smaller in the sample of randomly matched couples. At least part of our findings therefore originate from assortative mating.

To summarize, we find that accounting for personal information of the spouse matters for IOp as our estimate of the IOR increases by up to 20 (35) percent for gross (net) earnings. The less the responsibility assumed for the partner's variables, the higher the IOp measure. The question as to which scenario is most suitable cannot be answered without moral judgment and inclusion of the context of the research question. Given that the partner's variables were completely omitted from analysis in previous studies, the implicit assumption was full responsibility for all partner's variables. It might be questioned whether this was intentional or rather inadvertent. Particularly in the context of increased assortative mating and its potential role for changing inequality, explicitly accounting for the partner (or not) is important when measuring IOp. 


\section{References}

Aaberge, R., Aslaksen, I. and Wennemo, T. (2005). 'birds of a feather flock together': The impact of choice of spouse on family labor income inequality., Labour 19(3): $491-515$.

Aaberge, R., Mogstad, M. and Peragine, V. (2011). Measuring long-term inequality of opportunity, Journal of Public Economics 95(3): 193-204.

Blackburn, M. L. (2007). Estimating wage differentials without logarithms, Labour Economics 14(1): 73-98.

Bourguignon, F., Ferreira, F. H. and Menendez, M. (2007). Inequality of opportunity in brazil, Review of income and Wealth 53(4): 585-618.

Browning, M., Chiappori, P.-A. and Weiss, Y. (2013). Family Economics, Camebridge University Press.

Burtless, G. (1999). Effects of growing wage disparities and changing family composition on the us income distribution, European Economic Review 43(4): 853-865.

Checchi, D. and Peragine, V. (2010). Inequality of opportunity in Italy, The Journal of Economic Inequality 8(4): 429-450.

Chiappori, P.-A. and Meghir, C. (2014). Intrahousehold inequality., NBER working paper series 20191.

Ferreira, F. H. G. and Peragine, V. (2015). Equality of opportunity: Theory and evidence, IZA Discussion Paper No. 8994.

Ferreira, F. H. and Gignoux, J. (2011). The measurement of inequality of opportunity: Theory and an application to latin america, Review of Income and Wealth 57(4): 622-657.

Fleurbaey, M. (1995). Three solutions for the compensation problem, Journal of Economic Theory 65(2): 505-521.

Fleurbaey, M. and Peragine, V. (2013). Ex ante versus ex post equality of opportunity, Economica 80(317): 118-130.

Foster, J. E. and Shneyerov, A. A. (2000). Path independent inequality measures, Journal of Economic Theory 91(2): 199-222.

Haisken De-New, J. and Frick, J. (2003). Dtc-desktop compendium to the german socio-economic panel study (gsoep), Deutsches Institut für Wirtschaftsforschung . 
Lefranc, A., Pistolesi, N. and Trannoy, A. (2008). Inequality of opportunities vs. inequality of outcomes: Are western societies all alike?, Review of Income and Wealth 54(4): 513-546.

Lefranc, A., Pistolesi, N. and Trannoy, A. (2009). Equality of opportunity and luck: Definitions and testable conditions, with an application to income in france, Journal of Public Economics 93(11): 1189-1207.

Lise, J. and Seitz, S. (2011). Consumption inequality and intra-household allocations, The Review of Economic Studies 78(1): 328-355.

Niehues, J. and Peichl, A. (2014). Upper bounds of inequality of opportunity: theory and evidence for germany and the us, Social Choice and Welfare 43(1): 73-99.

Pestel, N. (2014). Beyond inequality accounting: Marital sorting and couple labor supply, IZA Discussion Paper $\mathbf{8 4 8 2 .}$

Ramos, X. and Van de gaer, D. (2012). Empirical approaches to inequality of opportunity: principles, measures, and evidence, IZA Discussion Paper 6672.

Roemer, J. (1998). Equality of Opportunity, Harvard University Press.

Roemer, J. E. (1993). A pragmatic theory of responsibility for the egalitarian planner, Philosophy \& Public Affairs pp. 146-166.

Roemer, J. and Trannoy, A. (2015). Equality of opportunity: Theory and measurement, Journal of Economic Literature.

Schwartz, C. R. and Mare, R. D. (2005). Trends in educational assortative marriage from 1940 to 2003., Demography 42(4): $621-646$.

Shorrocks, A. F. (1980). The class of additively decomposable inequality measures, Econometrica: Journal of the Econometric Society pp. 613-625.

Socio-Economic Panel (SOEP) (2013). data for years 1984-2012. version 29, SOEP, 2013, doi:10.5684/soep.v29.

Van de gaer, D. (1993). Equality of opportunity and investment in human capital, Working paper, KU Leuven.

Wagner, G. G., Frick, J. R. and Schupp, J. (2007). The german socio-economic panel study (soep)-evolution, scope and enhancements, Schmollers Jahrbuch 127: 139 170 . 


\section{A Appendix}

\section{A.1 Descriptive statistics}

Table A.1: Descriptive Statistics for Basic Variables

\begin{tabular}{lcccc}
\hline Variable & Mean & Sd & Min & Max \\
\hline Real Gross Earnings & 29011.91 & 23842.98 & 25 & 900562.9 \\
Real Net Earnings & 20832.51 & 15749.37 & 22.15 & 505810.9 \\
Gender & .48 & .5 & 0 & 1 \\
Ethnic & .06 & .24 & 0 & 1 \\
East Germany & .21 & .4 & 0 & 1 \\
Real Gross Earnings P & 28293.07 & 23836.27 & 25 & 900562.9 \\
Real Net Earnings P & 20301.59 & 15763.62 & 22.15 & 505810.9 \\
\hline
\end{tabular}

Table A.2: Descriptive Statistics for IOp Measures

\begin{tabular}{cccccccc}
\hline & \multicolumn{4}{c}{ IOR Gross Income } & \multicolumn{3}{c}{ IOR Net Income } \\
Year & EO & Case 1 & Case 2 & Case 3 & Case 1 & Case 2 & Case 3 \\
\hline 1991 & .29 & 45.35 & 46.34 & 49.13 & 46.82 & 47.97 & 55.28 \\
1992 & .33 & 42.11 & 42.38 & 46.93 & 44.42 & 44.71 & 56.31 \\
1993 & .33 & 44.03 & 46.04 & 49.64 & 46.35 & 48.79 & 57.31 \\
1994 & .34 & 43.14 & 44.39 & 47.15 & 44.77 & 46.31 & 54.33 \\
1995 & .33 & 44.09 & 45.3 & 48.85 & 46.28 & 47.9 & 58.3 \\
1996 & .32 & 43.25 & 44.45 & 50.2 & 45.85 & 47.24 & 61.96 \\
1997 & .32 & 40.13 & 41.04 & 48.93 & 42.37 & 43.39 & 62.66 \\
1998 & .35 & 42.5 & 44.65 & 48.49 & 45.51 & 47.82 & 58.5 \\
1999 & .33 & 43.07 & 45.68 & 49.73 & 45.99 & 48.31 & 60.26 \\
2000 & .36 & 42.04 & 42.94 & 45.25 & 45.84 & 46.74 & 59.26 \\
2001 & .35 & 43.46 & 44.47 & 47.08 & 47.69 & 48.9 & 58.99 \\
2002 & .35 & 41.95 & 43.63 & 45.49 & 45.01 & 46.47 & 54.47 \\
2003 & .35 & 39.09 & 40.51 & 43.4 & 43.04 & 44.37 & 57.51 \\
2004 & .35 & 39.23 & 41.06 & 44.8 & 42.91 & 44.44 & 55.91 \\
2005 & .37 & 37.55 & 40.24 & 45.42 & 40.63 & 43.08 & 56.95 \\
2006 & .35 & 38.21 & 41.88 & 45.4 & 41.18 & 44.86 & 56.09 \\
2007 & .39 & 39.86 & 43.78 & 49.88 & 43.37 & 47.32 & 59.56 \\
2008 & .37 & 43.27 & 47.44 & 50.88 & 45.77 & 50.33 & 58.82 \\
2009 & .37 & 38.49 & 42.1 & 47.12 & 41.03 & 44.62 & 56.58 \\
2010 & .37 & 42.69 & 45.8 & 49.47 & 45 & 48 & 58.81 \\
2011 & .37 & 38.12 & 42.22 & 47.19 & 40.71 & 44.86 & 55.2 \\
\hline
\end{tabular}




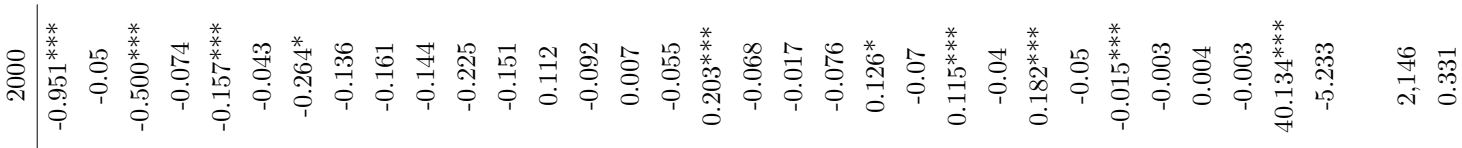

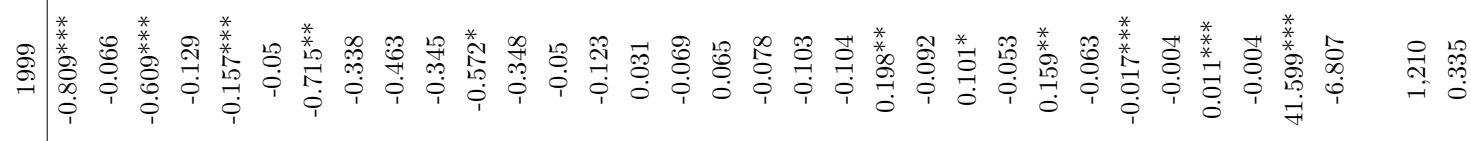

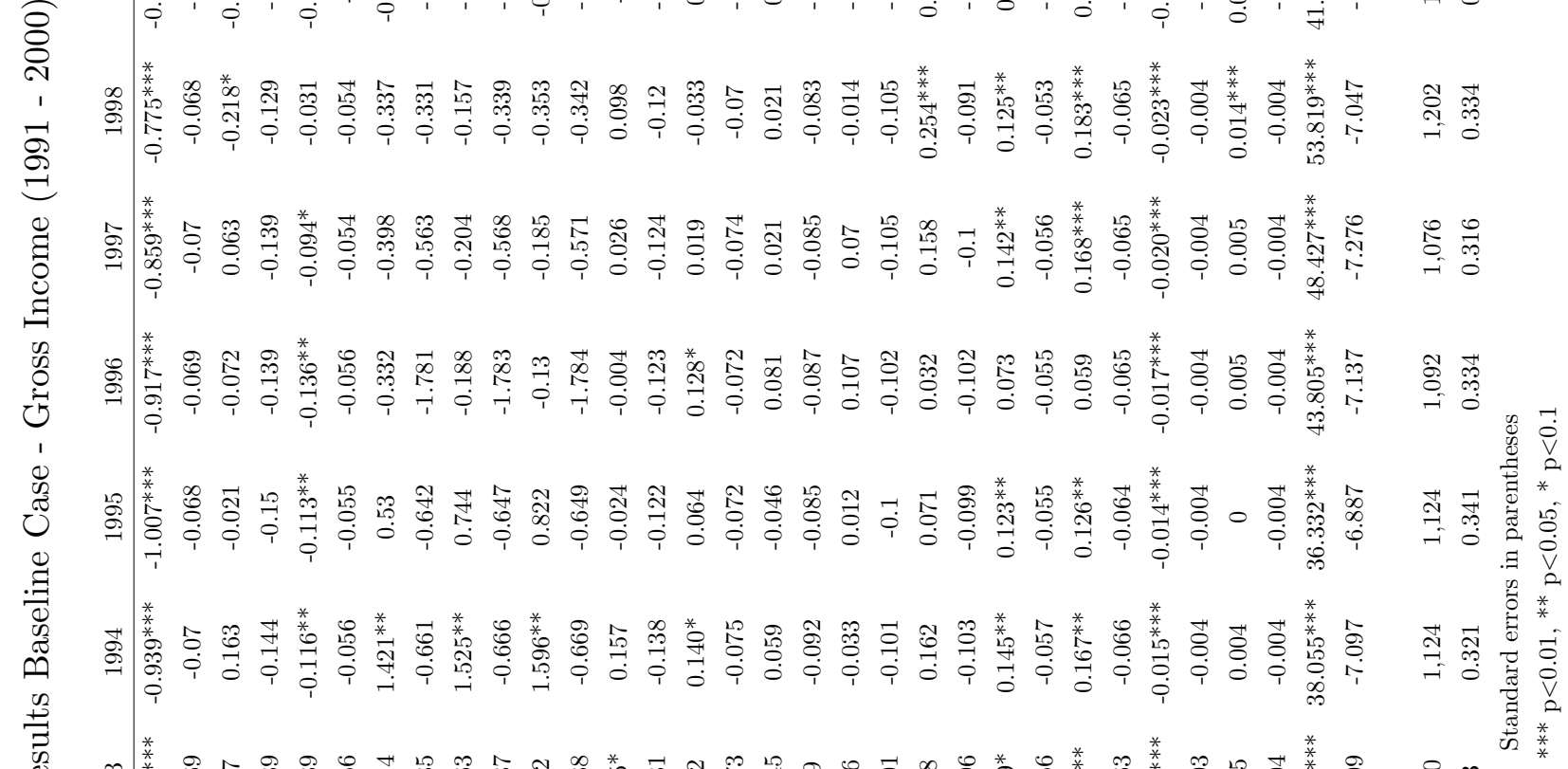

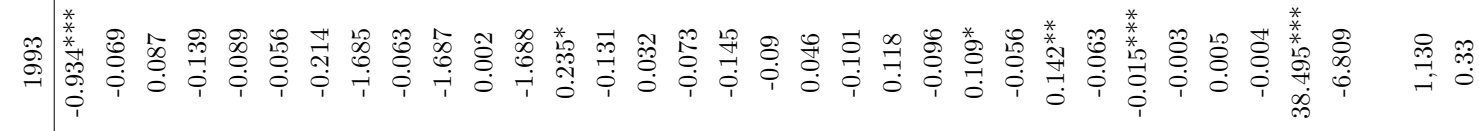

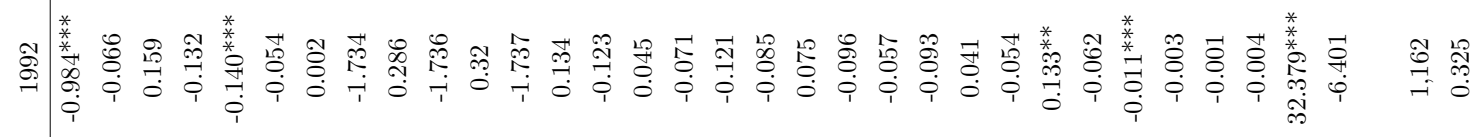

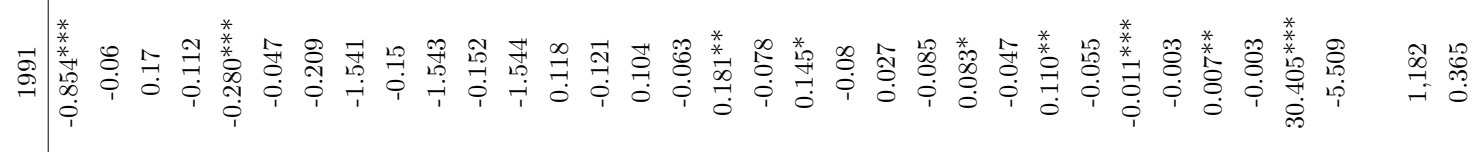

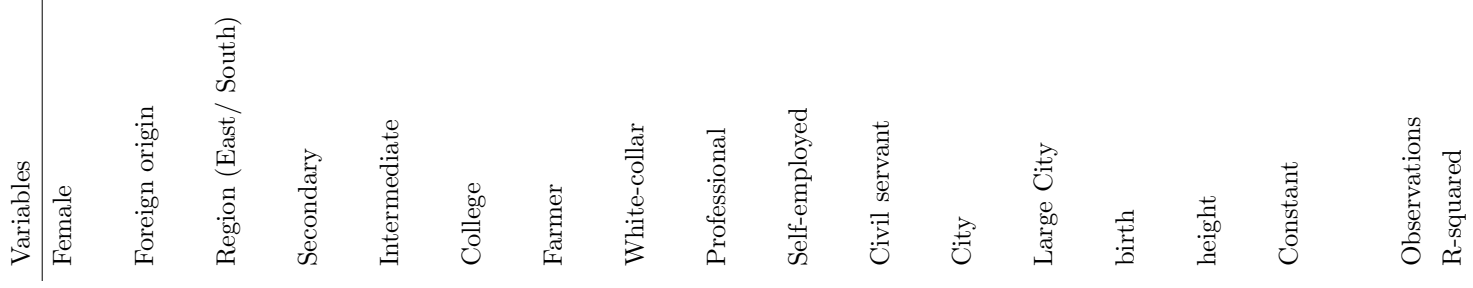




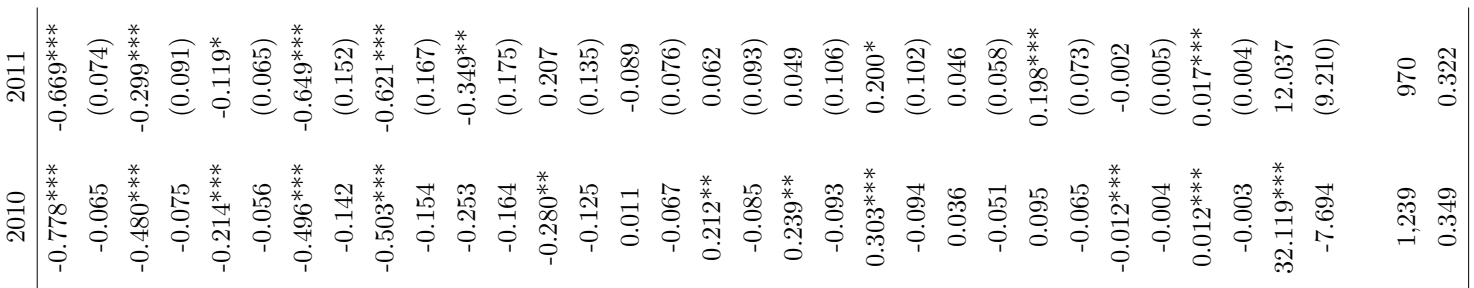

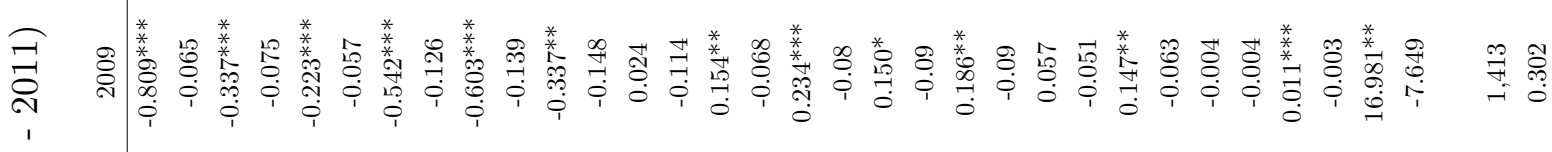

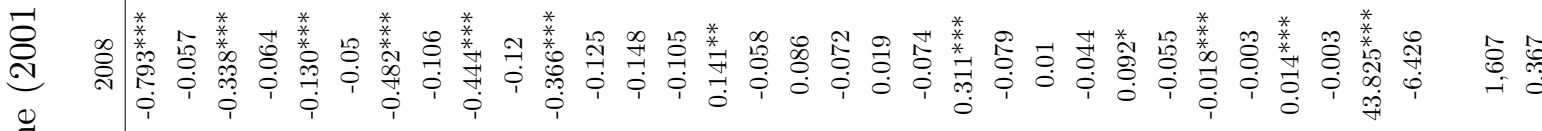

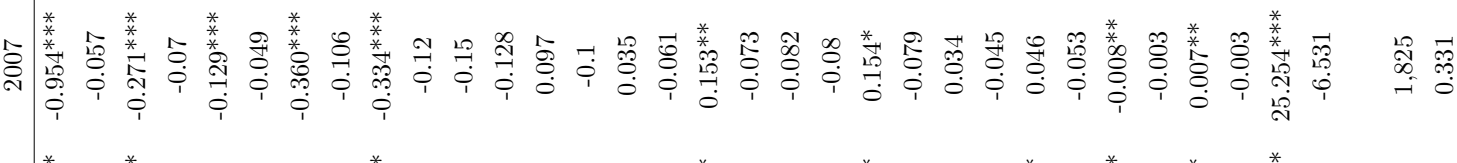

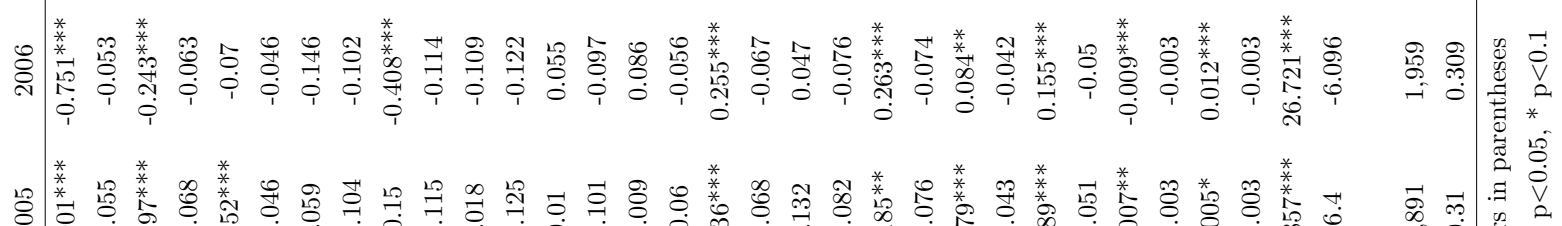

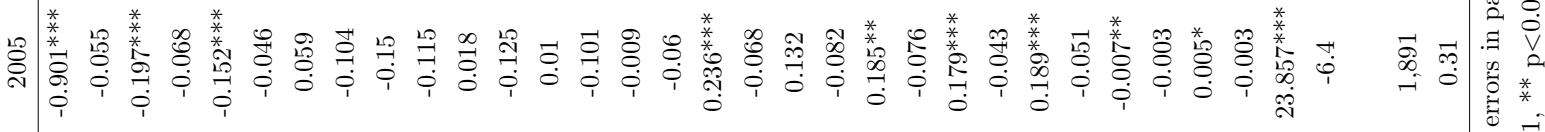

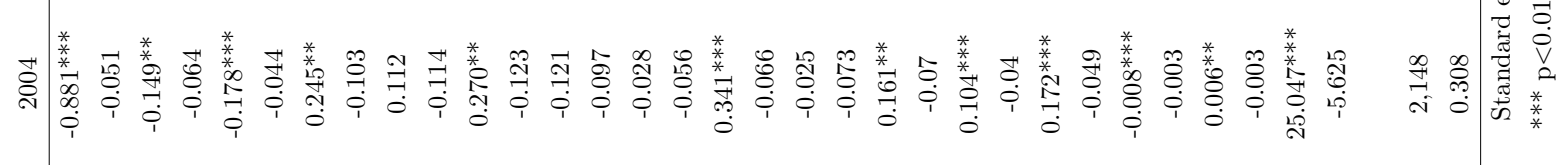

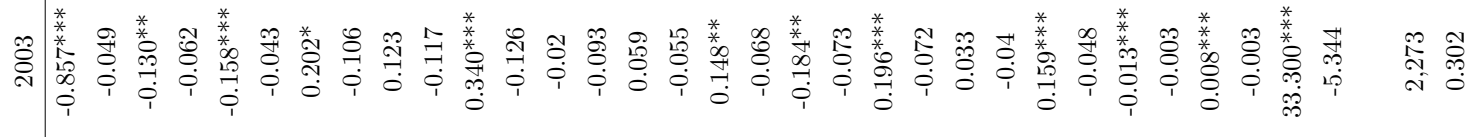

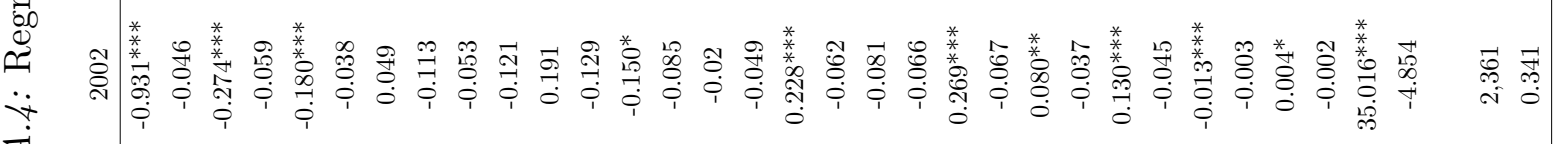

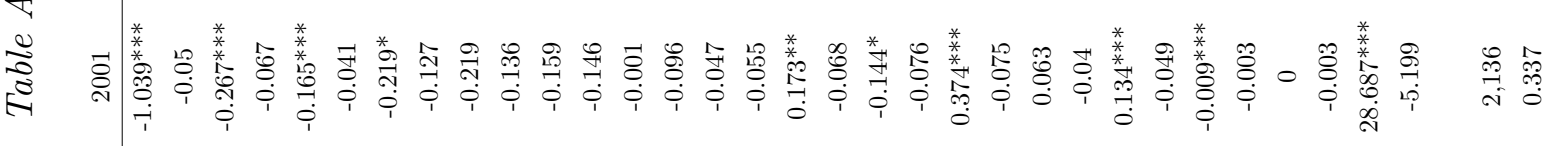

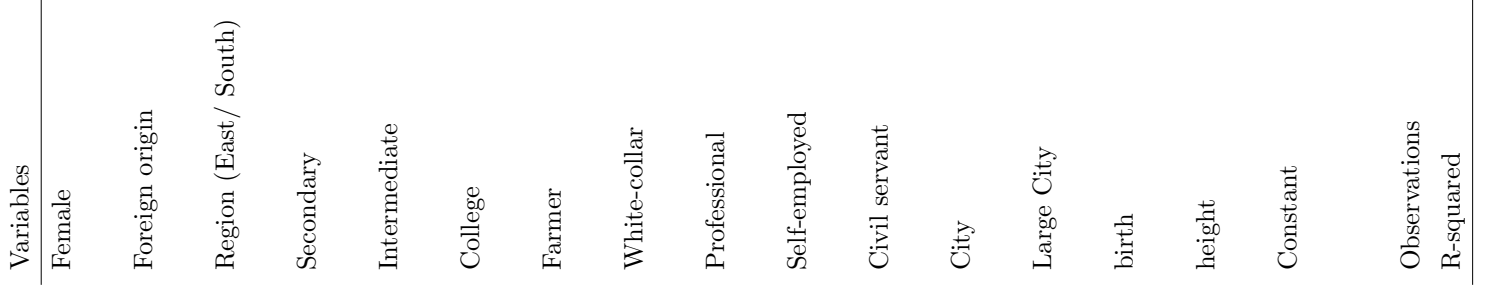




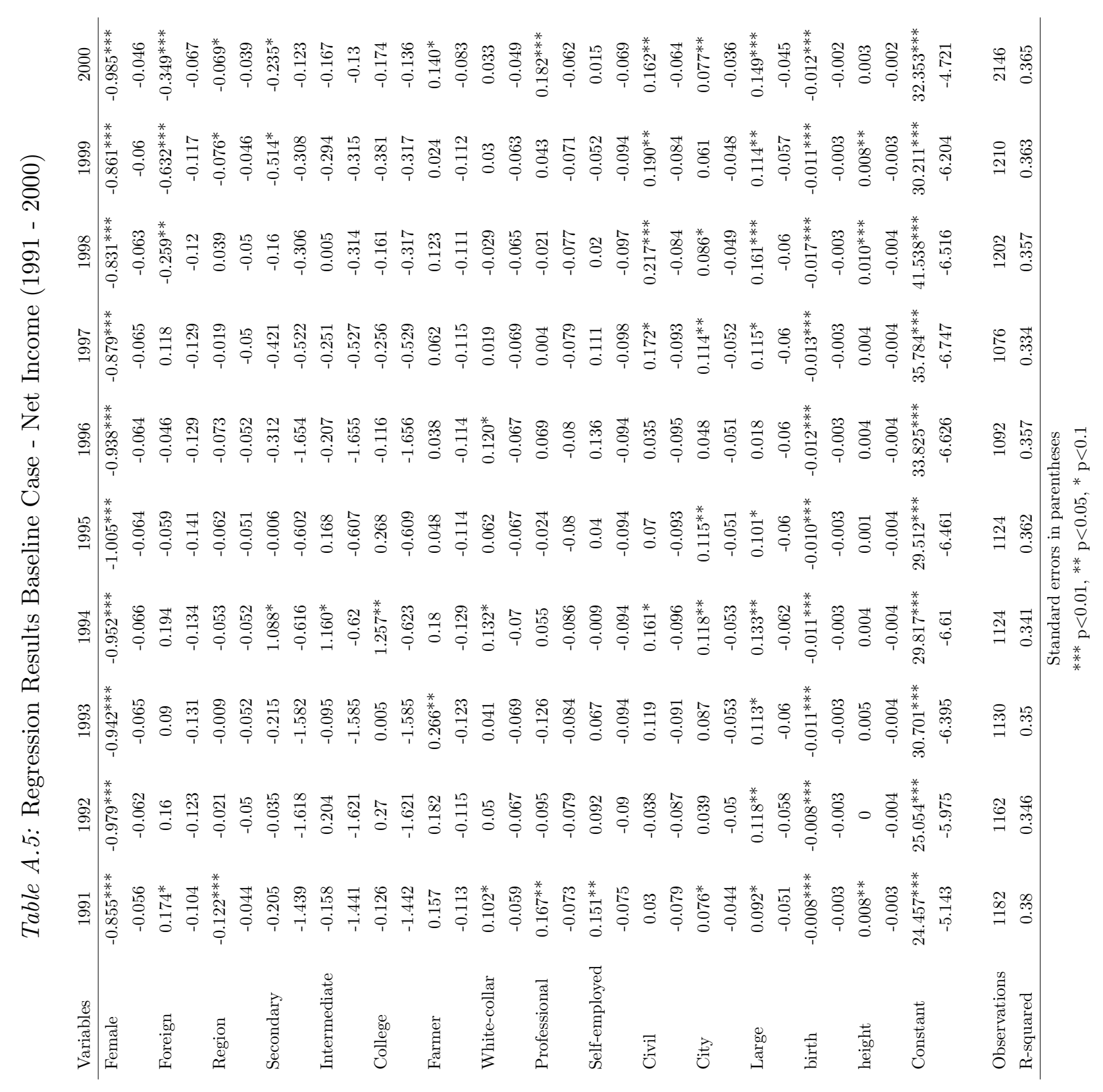




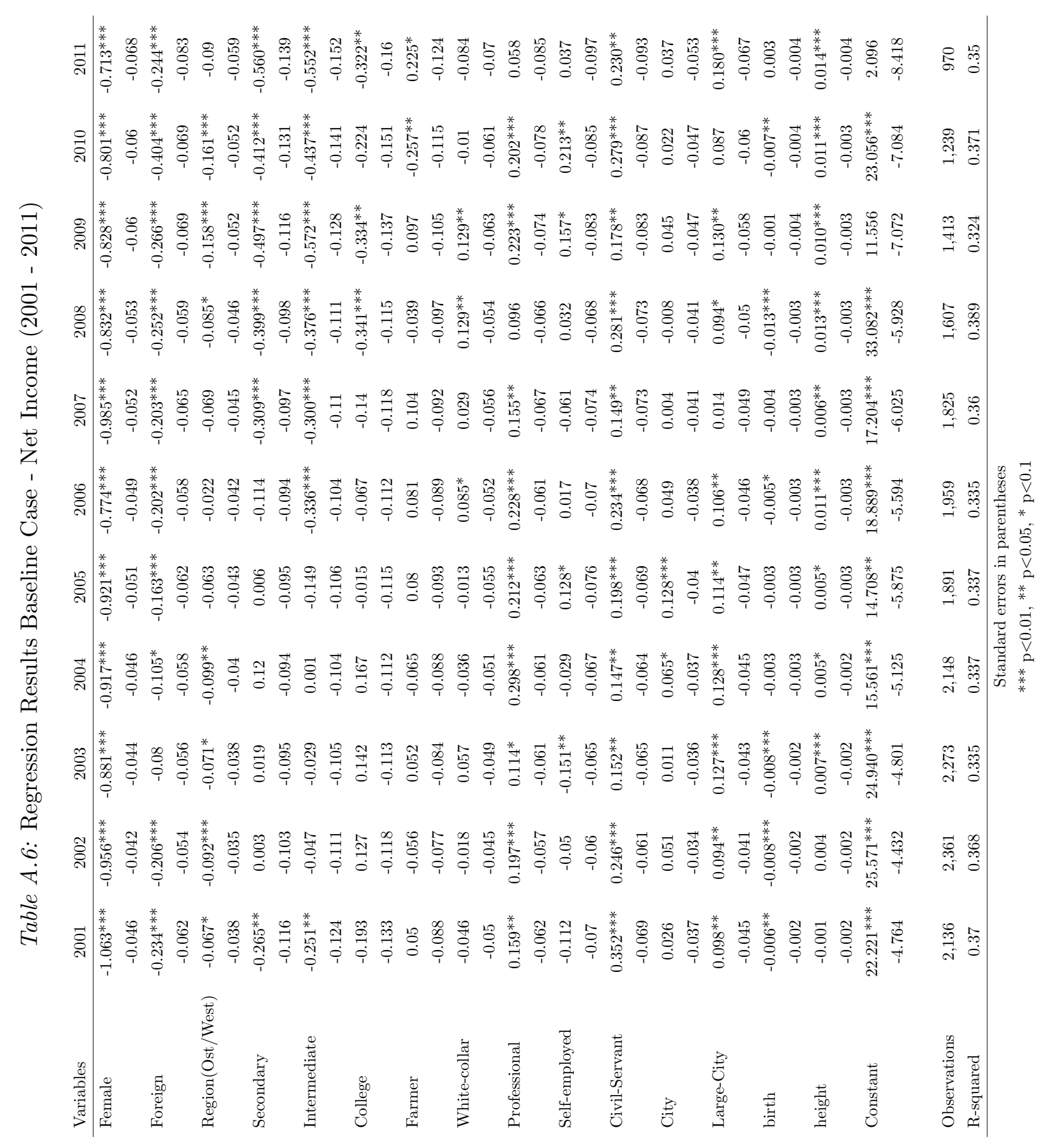


Table A.7: Regression Results Full Responsibility - Gross Income (1999-2000)

\begin{tabular}{|c|c|c|c|c|}
\hline Variables & 1991 & 1992 & 1993 & 1994 \\
\hline Female & & & $-0.732^{* * * *}$ & \\
\hline & -6.048 & -7.030 & $\begin{array}{l}-7.429 \\
(0.107)\end{array}$ & -7.576 \\
\hline Foreign origin & 0.132 & 0.070 & 0.048 & 0.065 \\
\hline & $(0.116)$ & $(0.138)$ & $(0.143)$ & $(0.150)$ \\
\hline Region (East/South) & $-0.221^{* * * *}$ & -0.397 & $-0.846^{*}$ & $-0.564^{*}$ \\
\hline & $(0.051)$ & $(0.635)$ & $(0.446)$ & $(0.315)$ \\
\hline Secondary & -0.288 & 0.033 & -0.523 & 0.856 \\
\hline & -1.536 & -1.724 & -1.670 & -1.364 \\
\hline Intermediate & -0.262 & 0.281 & -0.385 & 0.908 \\
\hline & -1.538 & -1.727 & -1.673 & -1.367 \\
\hline College & -0.241 & 0.365 & -0.314 & 0.980 \\
\hline & -1.539 & -1.727 & -1.673 & -1.368 \\
\hline Farmer & 0.084 & 0.106 & 0.206 & 0.134 \\
\hline & $(0.122)$ & $(0.123)$ & $(0.131)$ & $(0.140)$ \\
\hline White-collar & 0.086 & 0.015 & 0.010 & 0.123 \\
\hline & $(0.065)$ & $(0.073)$ & $(0.074)$ & $(0.078)$ \\
\hline Professional & $0.168^{* *}$ & -0.105 & $-0.165^{*}$ & -0.016 \\
\hline & $(0.080)$ & $(0.088)$ & $(0.093)$ & $(0.095)$ \\
\hline Self-employed & 0.116 & 0.053 & 0.059 & -0.035 \\
\hline & $(0.082)$ & $(0.097)$ & $(0.101)$ & $(0.103)$ \\
\hline Civil servant & 0.020 & -0.070 & 0.130 & 0.127 \\
\hline & $(0.087)$ & $(0.096)$ & $(0.098)$ & $(0.105)$ \\
\hline City & 0.065 & 0.028 & 0.085 & $0.134^{* *}$ \\
\hline & $(0.049)$ & $(0.056)$ & $(0.058)$ & $(0.060)$ \\
\hline Large City & 0.054 & 0.086 & 0.110 & $0.162^{\text {*** }}$ \\
\hline & $(0.065)$ & $(0.071)$ & $(0.072)$ & $(0.076)$ \\
\hline birth & $-0.017^{* * * *}$ & $-0.013^{*}$ & $-0.027^{* * *}$ & $-0.020^{* * *}$ \\
\hline & $(0.006)$ & $(0.007)$ & $(0.007)$ & $(0.007)$ \\
\hline height & $0.007^{* *}$ & -0.001 & 0.005 & 0.004 \\
\hline & $(0.004)$ & $(0.004)$ & $(0.004)$ & $(0.004)$ \\
\hline Partner Variables & & & & \\
\hline Female & $0.666^{* * * *}$ & $0.787^{* * *}$ & & $0.856^{* * *}$ \\
\hline & $(0.094)$ & $(0.104)$ & & $(0.112)$ \\
\hline Region (East/ South) & & 0.310 & $0.858^{*}$ & 0.493 \\
\hline & & $(0.635)$ & $(0.445)$ & $(0.315)$ \\
\hline Foreign origin & -0.028 & 0.085 & -0.106 & -0.054 \\
\hline & $(0.122)$ & $(0.144)$ & $(0.151)$ & $(0.158)$ \\
\hline Secondary & -0.735 & -0.653 & -0.944 & 0.476 \\
\hline & -1.588 & -1.781 & -1.735 & -1.373 \\
\hline Intermediate & -0.783 & -0.561 & -1.025 & 0.534 \\
\hline & -1.590 & -1.784 & -1.738 & -1.376 \\
\hline College & -0.674 & -0.675 & -1.209 & 0.489 \\
\hline & -1.591 & -1.786 & -1.739 & -1.378 \\
\hline Farmer & 0.059 & -0.102 & -0.083 & 0.070 \\
\hline & $(0.121)$ & $(0.123)$ & $(0.134)$ & $(0.144)$ \\
\hline White-Collar & 0.053 & 0.002 & 0.011 & 0.102 \\
\hline & $(0.065)$ & $(0.073)$ & $(0.074)$ & $(0.076)$ \\
\hline Professional & $0.153^{*}$ & 0.037 & 0.129 & 0.126 \\
\hline & $(0.080)$ & $(0.088)$ & $(0.093)$ & $(0.095)$ \\
\hline Self-employed & $0.140^{*}$ & -0.018 & 0.143 & 0.148 \\
\hline & $(0.080)$ & $(0.096)$ & $(0.100)$ & $(0.101)$ \\
\hline Civil servant & 0.041 & 0.008 & $0.178^{*}$ & 0.018 \\
\hline & $(0.086)$ & $(0.095)$ & $(0.098)$ & $(0.105)$ \\
\hline City & 0.065 & -0.035 & 0.031 & 0.005 \\
\hline & $(0.049)$ & $(0.055)$ & $(0.058)$ & $(0.060)$ \\
\hline Large city & 0.094 & 0.032 & 0.080 & 0.022 \\
\hline & $(0.065)$ & $(0.071)$ & $(0.072)$ & $(0.076)$ \\
\hline birth & 0.008 & 0.001 & $0.013^{*}$ & 0.006 \\
\hline & $(0.006)$ & $(0.007)$ & $(0.007)$ & $(0.007)$ \\
\hline height & -0.001 & 0.000 & 0.003 & 0.004 \\
\hline & $(0.004)$ & $(0.004)$ & $(0.004)$ & $(0.0$ \\
\hline Experience & $-0.074^{* *}$ & $-0.065^{*}$ & -0.045 & $-0.075^{* *}$ \\
\hline & $(0.029)$ & $(0.033)$ & $(0.035)$ & $(0.037)$ \\
\hline Sq experience & -0.010 & -0.021 & 0.001 & 0.025 \\
\hline & $(0.019)$ & $(0.023)$ & $(0.023)$ & $(0.025)$ \\
\hline Weekly hours & $-0.005^{* *}$ & $-0.010^{* * * *}$ & $-0.010^{* * *}$ & -0.002 \\
\hline & $(0.002)$ & $(0.002)$ & $(0.002)$ & $(0.002)$ \\
\hline Education & -0.014 & -0.013 & 0.010 & 0.015 \\
\hline & $(0.012)$ & $(0013)$ & $(0.013)$ & ) \\
\hline Energy and Mining & -0.121 & -0.007 & -0.051 & -0.141 \\
\hline & $(0.084)$ & $(0.093)$ & $(0.096)$ & $(0.102)$ \\
\hline Engineering & -0.137 & -0.098 & -0.081 & -0.067 \\
\hline & $(0.100)$ & $(0.114)$ & $(0.120)$ & $(0.115)$ \\
\hline Manufacturing & 0.005 & 0.116 & 0.002 & -0.088 \\
\hline & $(0.103)$ & $(0.120)$ & $(0.123)$ & $(0.127)$ \\
\hline Construction & -0.018 & 0.006 & -0.080 & $-0.199^{*}$ \\
\hline & $(0.101)$ & $(0+10)$ & s1: & $(0.113)$ \\
\hline Sales & -0.120 & -0.067 & $-0.172^{*}$ & -0.078 \\
\hline & $(0.086)$ & $(0.094)$ & $(0.097)$ & $(0.099)$ \\
\hline Transport & -0.151 & -0.202 & -0.184 & -0.211 \\
\hline & $(0.115)$ & $(0.125)$ & $(0.137)$ & $(0.137)$ \\
\hline Financial & 0.085 & 0.159 & 0.121 & 0.036 \\
\hline & $(0.130)$ & $(0.143)$ & $(0.145)$ & $(0.147)$ \\
\hline Service & -0.010 & 0.088 & -0.008 & $-0.275^{* * *}$ \\
\hline & $(0.100)$ & $(0.104)$ & $(0.106)$ & $(0.106)$ \\
\hline Education & 0.021 & 0.088 & -0.127 & -0.128 \\
\hline & 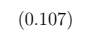 & & (0. & $(0.1$ \\
\hline Health & -0.123 & -0.124 & -0.133 & -0.162 \\
\hline & & .103) & $(0.108)$ & $(0.112)$ \\
\hline Constant & $28.294^{* * *}$ & $32.917^{* * *}$ & $37.227^{* * *}$ & $33.739^{* * *}$ \\
\hline Observatic & $1,1 \xi$ & 1,162 & 1,13 & 1,124 \\
\hline R-squared & 0.389 & 0.354 & 0.365 & 0.345 \\
\hline & & & & \\
\hline
\end{tabular}


Table A.8: Regression Results Full Responsibility - Gross Income (2001-2011)

\begin{tabular}{|c|c|c|c|c|c|c|c|c|c|c|c|}
\hline Variables & 2001 & 2002 & 2003 & 2004 & 2005 & 2006 & 2007 & 2008 & 2009 & 2010 & 2011 \\
\hline \multirow[t]{2}{*}{ Female } & $-0.969^{* * * *}$ & $-0.875^{* * * *}$ & & $-0.860^{* * * *}$ & $-0.756^{\text {**** }}$ & $-0.601^{* * * *}$ & & & & $-0.709^{* * * *}$ & \\
\hline & $\begin{array}{l}-5.501 \\
(0.080)\end{array}$ & $\begin{array}{l}-5.121 \\
(0.073)\end{array}$ & -5.627 & $\begin{array}{l}-5.882 \\
(0.079)\end{array}$ & $\begin{array}{l}-6.675 \\
(0.084)\end{array}$ & $\begin{array}{l}-6.416 \\
(0.080)\end{array}$ & -6.729 & -6.665 & -7.813 & $\begin{array}{l}-8.006 \\
(0.102)\end{array}$ & $(9.438)$ \\
\hline Foreign origin & $\begin{array}{c}-0.312^{* * * *} \\
(0.087)\end{array}$ & $\begin{array}{c}-0.297 * * * \\
(0.075)\end{array}$ & $\begin{array}{c}-0.174^{* *} \\
(0.082)\end{array}$ & $\begin{array}{c}-0.197^{* * *} \\
(0.084)\end{array}$ & $\begin{array}{c}-0.247^{* * *} \\
(0.082)\end{array}$ & $\begin{array}{c}-0.337^{* * *} \\
(0.073)\end{array}$ & $\begin{array}{c}-0.285^{* * *} \\
(0.081)\end{array}$ & $\begin{array}{c}-0.404^{* * *} \\
(0.082)\end{array}$ & $\begin{array}{c}-0.424^{* * *} \\
(0.095)\end{array}$ & $\begin{array}{c}-0.566^{* * * *} \\
(0.098)\end{array}$ & $\begin{array}{c}-0.346^{* * * *} \\
(0.123)\end{array}$ \\
\hline Region (East/ South) & $\begin{array}{c}-0.281^{* *} \\
(0.142)\end{array}$ & $\begin{array}{l}-0.188 \\
(0.143)\end{array}$ & $\begin{array}{l}-0.112 \\
(0.184)\end{array}$ & $\begin{array}{c}0.188 \\
(0.170)\end{array}$ & $\begin{array}{l}-0.055 \\
(0.179)\end{array}$ & $\begin{array}{c}0.079 \\
(0.165)\end{array}$ & $\begin{array}{c}0.175 \\
(0.166)\end{array}$ & $\begin{array}{c}-0.807^{* * *} \\
(0.164)\end{array}$ & $\begin{array}{l}-0.250 \\
(0.178)\end{array}$ & $\begin{array}{c}-0.349^{* *} \\
(0.177)\end{array}$ & $\begin{array}{l}-0.253 \\
(0.286)\end{array}$ \\
\hline Secondary & $\begin{array}{l}-0.280^{*} \\
(0.149)\end{array}$ & $\begin{array}{l}-0.003 \\
(0.127)\end{array}$ & $\begin{array}{c}0.161 \\
(0.119)\end{array}$ & $\begin{array}{c}0.081 \\
(0.123)\end{array}$ & $\begin{array}{c}0.024 \\
(0.116)\end{array}$ & $\begin{array}{l}-0.155 \\
(0.107)\end{array}$ & $\begin{array}{c}-0.344^{* * *} \\
(0.107)\end{array}$ & $\begin{array}{c}-0.501^{* * *} \\
(0.109)\end{array}$ & $\begin{array}{c}-0.661^{* * * *} \\
(0.130)\end{array}$ & $\begin{array}{c}-0.471^{* * * *} \\
(0.148)\end{array}$ & $\begin{array}{c}-0.673^{* * * *} \\
(0.159)\end{array}$ \\
\hline Intermediate & $\begin{array}{c}-0.315^{* * *} \\
(0.158)\end{array}$ & $\begin{array}{l}-0.143 \\
(0.135)\end{array}$ & $\begin{array}{c}0.041 \\
(0.128)\end{array}$ & $\begin{array}{l}-0.076 \\
(0.129)\end{array}$ & $\begin{array}{c}-0.248 * * \\
(0.125)\end{array}$ & $\begin{array}{c}-0.466^{* * *} \\
(0.117)\end{array}$ & $\begin{array}{c}-0.336^{* * *} \\
(0.120)\end{array}$ & $\begin{array}{c}-0.513^{* * *} \\
(0.121)\end{array}$ & $\begin{array}{c}-0.728^{* * * *} \\
(0.141)\end{array}$ & $\begin{array}{c}-0.499^{* * *} \\
(0.157)\end{array}$ & $\begin{array}{c}-0.642^{* * * *} \\
(0.172)\end{array}$ \\
\hline College & $\begin{array}{l}-0.272 \\
(0.166)\end{array}$ & $\begin{array}{c}0.096 \\
(0.143)\end{array}$ & $\begin{array}{l}0.241^{*} \\
(0.138)\end{array}$ & $\begin{array}{c}0.022 \\
(0.139)\end{array}$ & $\begin{array}{l}-0.119 \\
(0.137)\end{array}$ & $\begin{array}{l}-0.245^{*} \\
(0.128)\end{array}$ & $\begin{array}{c}-0.296^{* *} \\
(0.129)\end{array}$ & $\begin{array}{c}-0.521^{* * * *} \\
(0.129)\end{array}$ & $\begin{array}{c}-0.536^{* * *} \\
(0.152)\end{array}$ & $\begin{array}{c}-0.347^{* *} \\
(0.169)\end{array}$ & $\begin{array}{c}-0.555^{* * * *} \\
(0.182)\end{array}$ \\
\hline Farmer & $\begin{array}{c}0.010 \\
(0.097)\end{array}$ & $\begin{array}{l}-0.143^{*} \\
(0.086)\end{array}$ & $\begin{array}{c}0.001 \\
(0.094)\end{array}$ & $\begin{array}{l}-0.129 \\
(0.096)\end{array}$ & $\begin{array}{l}-0.013 \\
(0.099)\end{array}$ & $\begin{array}{c}0.023 \\
(0.096)\end{array}$ & $\begin{array}{c}0.057 \\
(0.097)\end{array}$ & $\begin{array}{l}-0.174^{*} \\
(0.104)\end{array}$ & $\begin{array}{c}0.004 \\
(0.113)\end{array}$ & $\begin{array}{c}-0.284^{* *} \\
(0.125)\end{array}$ & $\begin{array}{c}0.075 \\
(0.138)\end{array}$ \\
\hline White-collar & $\begin{array}{l}-0.064 \\
(0.055)\end{array}$ & $\begin{array}{l}-0.050 \\
(0.050)\end{array}$ & $\begin{array}{c}0.024 \\
(0.055)\end{array}$ & $\begin{array}{l}-0.078 \\
(0.056)\end{array}$ & $\begin{array}{l}-0.047 \\
(0.059)\end{array}$ & $\begin{array}{c}0.048 \\
(0.056)\end{array}$ & $\begin{array}{l}-0.031 \\
(0.059)\end{array}$ & $\begin{array}{c}0.044 \\
(0.058)\end{array}$ & $\begin{array}{c}0.072 \\
(0.068)\end{array}$ & $\begin{array}{l}-0.083 \\
(0.068)\end{array}$ & $\begin{array}{c}-0.192^{* * *} \\
(0.077)\end{array}$ \\
\hline Professional & $\begin{array}{l}0.122^{*} \\
(0.069)\end{array}$ & $\begin{array}{l}0.163^{* * *} \\
(0.063)\end{array}$ & $\begin{array}{c}0.095 \\
(0.068)\end{array}$ & $\begin{array}{c}0.241^{* * *} \\
(0.067)\end{array}$ & $\begin{array}{l}0.161^{* *} \\
(0.068)\end{array}$ & $\begin{array}{c}0.221^{* * *} \\
(0.067)\end{array}$ & $\begin{array}{c}0.085 \\
(0.071)\end{array}$ & $\begin{array}{c}0.019 \\
(0.071)\end{array}$ & $\begin{array}{l}0.142^{*} \\
(0.081)\end{array}$ & $\begin{array}{c}0.126 \\
(0.086)\end{array}$ & $\begin{array}{l}-0.034 \\
(0.093)\end{array}$ \\
\hline Self-employed & $\begin{array}{c}-0.153^{* *} \\
(0.076)\end{array}$ & $\begin{array}{l}-0.120^{*} \\
(0.065)\end{array}$ & $\begin{array}{c}-0.215^{* * *} \\
(0.072)\end{array}$ & $\begin{array}{l}-0.078 \\
(0.072)\end{array}$ & $\begin{array}{c}0.029 \\
(0.081)\end{array}$ & $\begin{array}{c}0.018 \\
(0.075)\end{array}$ & $\begin{array}{l}-0.105 \\
(0.079)\end{array}$ & $\begin{array}{l}-0.090 \\
(0.073)\end{array}$ & $\begin{array}{c}0.013 \\
(0.089)\end{array}$ & $\begin{array}{c}0.140 \\
(0.094)\end{array}$ & $\begin{array}{l}-0.045 \\
(0.108)\end{array}$ \\
\hline Civil servant & $\begin{array}{c}0.328^{* * *} \\
(0.075)\end{array}$ & $\begin{array}{c}0.213^{* * *} \\
(0.067)\end{array}$ & $\begin{array}{l}0.145^{* *} \\
(0.072)\end{array}$ & $\begin{array}{c}0.099 \\
(0.070)\end{array}$ & $\begin{array}{c}0.111 \\
(0.075)\end{array}$ & $\begin{array}{c}0.227^{* * *} \\
(0.073)\end{array}$ & $\begin{array}{c}0.068 \\
(0.076)\end{array}$ & $\begin{array}{c}0.239^{* * * *} \\
(0.078)\end{array}$ & $\begin{array}{c}0.086 \\
(0.089)\end{array}$ & $\begin{array}{l}0.235^{* *} \\
(0.096)\end{array}$ & $\begin{array}{c}0.084 \\
(0.102)\end{array}$ \\
\hline City & $\begin{array}{c}0.033 \\
(0.042)\end{array}$ & $\begin{array}{l}0.072^{*} \\
(0.039)\end{array}$ & & $\begin{array}{c}0.067 \\
(0.042)\end{array}$ & $\begin{array}{c}0.134^{* * * *} \\
(0.045)\end{array}$ & $\begin{array}{c}0.051 \\
(0.043)\end{array}$ & $\begin{array}{c}0.011 \\
(0.046)\end{array}$ & $\begin{array}{c}0.001 \\
(0.045)\end{array}$ & $\begin{array}{l}-0.012 \\
(0.052)\end{array}$ & $\begin{array}{c}0.017 \\
(0.053)\end{array}$ & $\begin{array}{c}0.020 \\
(0.060)\end{array}$ \\
\hline Large City & $\begin{array}{l}0.099^{*} \\
(0.055)\end{array}$ & $\begin{array}{c}0.105^{* * *} \\
(0.052)\end{array}$ & $\begin{array}{c}0.174^{* * * *} \\
(0.055)\end{array}$ & $\begin{array}{l}0.108^{* * *} \\
(0.054)\end{array}$ & $\begin{array}{c}0.090 \\
(0.055)\end{array}$ & $\begin{array}{c}0.051 \\
(0.054)\end{array}$ & $\begin{array}{l}-0.007 \\
(0.057)\end{array}$ & $\begin{array}{l}-0.013 \\
(0.059)\end{array}$ & $\begin{array}{l}-0.033 \\
(0.069)\end{array}$ & $\begin{array}{l}-0.030 \\
(0.072)\end{array}$ & $\begin{array}{c}0.110 \\
(0.080)\end{array}$ \\
\hline birth & $\begin{array}{c}-0.013^{* *} \\
(0.005)\end{array}$ & $\begin{array}{c}-0.011^{* *} \\
(0.005)\end{array}$ & $\begin{array}{c}-0.016^{* * *} \\
(0.005)\end{array}$ & $\begin{array}{l}-0.003 \\
(0.006)\end{array}$ & $\begin{array}{c}0.003 \\
(0.006)\end{array}$ & $\begin{array}{l}-0.002 \\
(0.005)\end{array}$ & $\begin{array}{l}-0.000 \\
(0.006)\end{array}$ & $\begin{array}{c}-0.019^{* * * *} \\
(0.006)\end{array}$ & $\begin{array}{l}-0.005 \\
(0.007)\end{array}$ & $\begin{array}{l}-0.011 \\
(0.008)\end{array}$ & $\begin{array}{l}-0.003 \\
(0.009)\end{array}$ \\
\hline height & $\begin{array}{l}-0.000 \\
(0.003)\end{array}$ & $\begin{array}{c}0.002 \\
(0.003)\end{array}$ & $\begin{array}{c}0.006^{* *} \\
(0.003)\end{array}$ & $\begin{array}{c}0.004 \\
(0.003)\end{array}$ & $\begin{array}{c}0.004 \\
(0.003)\end{array}$ & $\begin{array}{c}0.010^{* * *} \\
(0.003)\end{array}$ & $\begin{array}{c}0.006^{* *} \\
(0.003)\end{array}$ & $\begin{array}{c}0.014^{* * *} \\
(0.003)\end{array}$ & $\begin{array}{c}0.009^{* * * *} \\
(0.003)\end{array}$ & $\begin{array}{c}0.011^{* * *} \\
(0.004)\end{array}$ & $\begin{array}{c}0.014^{* * * *} \\
(0.004)\end{array}$ \\
\hline \multicolumn{12}{|l|}{ Partner $V_{s}$} \\
\hline Female & & & $\begin{array}{c}0.769^{* * * *} \\
(0.076)\end{array}$ & & & & $\begin{array}{c}0.698^{* * * *} \\
(0.083)\end{array}$ & $\begin{array}{c}0.682^{* * *} \\
(0.084)\end{array}$ & $\begin{array}{c}0.699^{* * * *} \\
(0.097)\end{array}$ & & $\begin{array}{c}0.660^{* * * *} \\
(0.112)\end{array}$ \\
\hline Region (East/ South) & $\begin{array}{c}0.149 \\
(0.142)\end{array}$ & $\begin{array}{c}0.040 \\
(0.143)\end{array}$ & $\begin{array}{l}-0.031 \\
(0.185)\end{array}$ & $\begin{array}{l}-0.325^{*} \\
(0.171)\end{array}$ & $\begin{array}{l}-0.040 \\
(0.179)\end{array}$ & $\begin{array}{l}-0.093 \\
(0.165)\end{array}$ & $\begin{array}{l}-0.215 \\
(0.167)\end{array}$ & $\begin{array}{c}0.725^{* * *} \\
(0.164)\end{array}$ & $\begin{array}{c}0.051 \\
(0.178)\end{array}$ & $\begin{array}{c}0.191 \\
(0.177)\end{array}$ & $\begin{array}{c}0.165 \\
(0.286)\end{array}$ \\
\hline Foreign origin & $\begin{array}{c}0.104 \\
(0.089)\end{array}$ & $\begin{array}{c}0.031 \\
(0.077)\end{array}$ & $\begin{array}{c}0.060 \\
(0.085)\end{array}$ & $\begin{array}{c}0.133 \\
(0.087)\end{array}$ & $\begin{array}{l}0.166^{* * *} \\
(0.083)\end{array}$ & $\begin{array}{c}0.239^{* * * *} \\
(0.075)\end{array}$ & $\begin{array}{c}0.102 \\
(0.084)\end{array}$ & $\begin{array}{l}0.157^{*} \\
(0.083)\end{array}$ & $\begin{array}{c}0.147 \\
(0.097)\end{array}$ & $\begin{array}{c}0.137 \\
(0.099)\end{array}$ & $\begin{array}{l}0.226^{*} \\
(0.124)\end{array}$ \\
\hline Secondary & $\begin{array}{c}0.058 \\
(0.148)\end{array}$ & $\begin{array}{c}0.003 \\
(0.125)\end{array}$ & $\begin{array}{c}0.047 \\
(0.119)\end{array}$ & $\begin{array}{l}0.215^{*} \\
(0.123)\end{array}$ & $\begin{array}{c}0.079 \\
(0.117)\end{array}$ & & $\begin{array}{l}-0.106 \\
(0.108)\end{array}$ & $\begin{array}{c}0.044 \\
(0.111)\end{array}$ & $\begin{array}{c}0.261^{* *} \\
(0.133)\end{array}$ & $\begin{array}{c}0.127 \\
(0.148)\end{array}$ & $\begin{array}{l}0.303^{*} \\
(0.159)\end{array}$ \\
\hline Intermediate & $\begin{array}{c}0.005 \\
(0.156)\end{array}$ & $\begin{array}{l}-0.088 \\
(0.132)\end{array}$ & $\begin{array}{l}-0.040 \\
(0.127)\end{array}$ & $\begin{array}{l}0.243^{*} \\
(0.129)\end{array}$ & $\begin{array}{c}0.033 \\
(0.125)\end{array}$ & $\begin{array}{c}0.054 \\
(0.117)\end{array}$ & $\begin{array}{l}-0.080 \\
(0.120)\end{array}$ & $\begin{array}{c}0.069 \\
(0.123)\end{array}$ & $\begin{array}{c}0.214 \\
(0.143)\end{array}$ & $\begin{array}{c}0.174 \\
(0.157)\end{array}$ & $\begin{array}{c}0.343^{* *} \\
(0.169)\end{array}$ \\
\hline College & $\begin{array}{c}0.019 \\
(0.165)\end{array}$ & $\begin{array}{c}0.119 \\
(0.141)\end{array}$ & $\begin{array}{c}0.002 \\
(0.138)\end{array}$ & $\begin{array}{c}0.104 \\
(0.139)\end{array}$ & $\begin{array}{c}0.110 \\
(0.137)\end{array}$ & $\begin{array}{c}0.002 \\
(0.128)\end{array}$ & $\begin{array}{l}-0.007 \\
(0.132)\end{array}$ & $\begin{array}{c}0.171 \\
(0.129)\end{array}$ & $\begin{array}{l}0.304^{* *} \\
(0.152)\end{array}$ & $\begin{array}{l}0.290^{*} \\
(0.168)\end{array}$ & $\begin{array}{l}0.438^{* *} \\
(0.180)\end{array}$ \\
\hline Farmer & $\begin{array}{l}-0.165^{*} \\
(0.098)\end{array}$ & $\begin{array}{c}-0.190^{* * *} \\
(0.086)\end{array}$ & $\begin{array}{c}-0.295^{* * * *} \\
(0.094)\end{array}$ & $\begin{array}{l}-0.109 \\
(0.097)\end{array}$ & $\begin{array}{c}-0.406^{* * * *} \\
(0.099)\end{array}$ & $\begin{array}{c}-0.255^{* * * *} \\
(0.097)\end{array}$ & $\begin{array}{c}0.015 \\
(0.098)\end{array}$ & $\begin{array}{l}-0.087 \\
(0.103)\end{array}$ & $\begin{array}{c}-0.451^{* * *} \\
(0.115)\end{array}$ & $\begin{array}{c}-0.258^{* *} \\
(0.128)\end{array}$ & $\begin{array}{l}-0.028 \\
(0.140)\end{array}$ \\
\hline White-Collar & $\begin{array}{c}0.022 \\
(0.055)\end{array}$ & $\begin{array}{l}0.125^{* *} \\
(0.050)\end{array}$ & $\begin{array}{c}0.003 \\
(0.056)\end{array}$ & $\begin{array}{c}0.066 \\
(0.056)\end{array}$ & $\begin{array}{c}0.064 \\
(0.059)\end{array}$ & $\begin{array}{c}0.032 \\
(0.055)\end{array}$ & $\begin{array}{c}0.080 \\
(0.058)\end{array}$ & $\begin{array}{l}-0.080 \\
(0.057)\end{array}$ & $\begin{array}{l}-0.046 \\
(0.067)\end{array}$ & $\begin{array}{c}0.111 \\
(0.068)\end{array}$ & $\begin{array}{c}0.118 \\
(0.077)\end{array}$ \\
\hline Professional & $\begin{array}{c}0.113 \\
(0.070)\end{array}$ & $\begin{array}{l}0.122^{*} \\
(0.064)\end{array}$ & $\begin{array}{c}0.138^{* *} \\
(0.069)\end{array}$ & $\begin{array}{l}0.145^{* *} \\
(0.068)\end{array}$ & $\begin{array}{c}0.112 \\
(0.069)\end{array}$ & $\begin{array}{c}0.197^{* * *} \\
(0.068)\end{array}$ & $\begin{array}{c}0.231^{* * *} \\
(0.072)\end{array}$ & $\begin{array}{c}0.102 \\
(0.071)\end{array}$ & $\begin{array}{c}0.018 \\
(0.081)\end{array}$ & $\begin{array}{c}0.129 \\
(0.088)\end{array}$ & $\begin{array}{l}0.234^{* *} \\
(0.094)\end{array}$ \\
\hline Self-employed & $\begin{array}{c}0.069 \\
(0.076)\end{array}$ & $\begin{array}{l}-0.017 \\
(0.066)\end{array}$ & $\begin{array}{l}-0.019 \\
(0.073)\end{array}$ & $\begin{array}{c}0.007 \\
(0.073)\end{array}$ & $\begin{array}{c}0.115 \\
(0.082)\end{array}$ & $\begin{array}{c}0.236^{* * *} \\
(0.075)\end{array}$ & $\begin{array}{l}0.147^{*} \\
(0.078)\end{array}$ & $\begin{array}{c}0.014 \\
(0.073)\end{array}$ & $\begin{array}{l}-0.045 \\
(0.089)\end{array}$ & $\begin{array}{c}0.134 \\
(0.094)\end{array}$ & $\begin{array}{c}0.100 \\
(0.107)\end{array}$ \\
\hline Civil servant & $\begin{array}{l}-0.080 \\
(0.076)\end{array}$ & $\begin{array}{l}-0.033 \\
(0.068)\end{array}$ & $\begin{array}{l}-0.039 \\
(0.073)\end{array}$ & $\begin{array}{c}0.072 \\
(0.071)\end{array}$ & $\begin{array}{l}-0.028 \\
(0.075)\end{array}$ & $\begin{array}{c}0.044 \\
(0.074)\end{array}$ & $\begin{array}{l}-0.004 \\
(0.078)\end{array}$ & $\begin{array}{l}-0.030 \\
(0.079)\end{array}$ & $\begin{array}{l}-0.154^{*} \\
(0.089)\end{array}$ & $\begin{array}{c}0.046 \\
(0.095)\end{array}$ & $\begin{array}{l}-0.045 \\
(0.101)\end{array}$ \\
\hline City & $\begin{array}{c}0.013 \\
(0.042)\end{array}$ & $\begin{array}{l}-0.033 \\
(0.039)\end{array}$ & $\begin{array}{c}0.025 \\
(0.042)\end{array}$ & $\begin{array}{c}0.053 \\
(0.042)\end{array}$ & $\begin{array}{c}0.038 \\
(0.045)\end{array}$ & $\begin{array}{c}0.059 \\
(0.044)\end{array}$ & $\begin{array}{c}0.053 \\
(0.046)\end{array}$ & $\begin{array}{c}0.029 \\
(0.045)\end{array}$ & $\begin{array}{c}0.122^{* *} \\
(0.052)\end{array}$ & $\begin{array}{c}0.035 \\
(0.053)\end{array}$ & $\begin{array}{l}-0.021 \\
(0.060)\end{array}$ \\
\hline Large city & $\begin{array}{c}0.008 \\
(0.055)\end{array}$ & $\begin{array}{c}0.002 \\
(0.052)\end{array}$ & $\begin{array}{l}-0.091^{*} \\
(0.055)\end{array}$ & $\begin{array}{c}0.073 \\
(0.054)\end{array}$ & $\begin{array}{l}0.129^{* *} \\
(0.055)\end{array}$ & $\begin{array}{l}0.135^{* *} \\
(0.054)\end{array}$ & $\begin{array}{c}0.062 \\
(0.057)\end{array}$ & $\begin{array}{l}0.107^{*} \\
(0.060)\end{array}$ & $\begin{array}{c}0.208^{* * * *} \\
(0.068)\end{array}$ & $\begin{array}{c}0.109 \\
(0.072)\end{array}$ & $\begin{array}{c}0.025 \\
(0.080)\end{array}$ \\
\hline birth & $\begin{array}{l}0.003 \\
(0.005)\end{array}$ & $\begin{array}{l}-0.002 \\
(0.005)\end{array}$ & $\begin{array}{c}0.004 \\
(0.005)\end{array}$ & $\begin{array}{l}-0.008 \\
(0.006)\end{array}$ & $\begin{array}{c}-0.014^{* *} \\
(0.006)\end{array}$ & $\begin{array}{c}-0.012^{* *} \\
(0.005)\end{array}$ & $\begin{array}{c}-0.012^{* *} \\
(0.006)\end{array}$ & $\begin{array}{l}-0.003 \\
(0.006)\end{array}$ & $\begin{array}{l}-0.002 \\
(0.007)\end{array}$ & $\begin{array}{l}-0.004 \\
(0.008)\end{array}$ & $\begin{array}{l}-0.003 \\
(0.009)\end{array}$ \\
\hline height & $\begin{array}{l}0.006^{* *} \\
(0.003)\end{array}$ & $\begin{array}{c}0.004 \\
(0.003)\end{array}$ & & $\begin{array}{l}0.005^{*} \\
(0.003)\end{array}$ & $\begin{array}{l}-0.001 \\
(0.003)\end{array}$ & $\begin{array}{l}0.000 \\
(0.003)\end{array}$ & & $\begin{array}{c}0.000 \\
(0.003)\end{array}$ & $\begin{array}{c}0.002 \\
(0.003)\end{array}$ & & $\begin{array}{c}0.003 \\
(0.004)\end{array}$ \\
\hline Experience & $\begin{array}{c}-0.064^{* * *} \\
(0.028)\end{array}$ & $\begin{array}{c}-0.061^{* *} \\
(0.027)\end{array}$ & $\begin{array}{l}-0.037 \\
(0.029)\end{array}$ & $\begin{array}{l}-0.011 \\
(0.030)\end{array}$ & $\begin{array}{l}-0.015 \\
(0.033)\end{array}$ & $\begin{array}{l}-0.038 \\
(0.032)\end{array}$ & $\begin{array}{l}-0.011 \\
(0.034)\end{array}$ & $\begin{array}{c}0.006 \\
(0.034)\end{array}$ & $\begin{array}{l}-0.042 \\
(0.039)\end{array}$ & $\begin{array}{c}0.042 \\
(0.042)\end{array}$ & $\begin{array}{c}0.038 \\
(0.049)\end{array}$ \\
\hline Sq experience & $\begin{array}{l}-0.023 \\
(0.018)\end{array}$ & $\begin{array}{l}-0.002 \\
(0.017)\end{array}$ & $\begin{array}{c}0.013 \\
(0.018)\end{array}$ & $\begin{array}{c}0.024 \\
(0.018)\end{array}$ & $\begin{array}{l}0.038^{*} \\
(0.020)\end{array}$ & $\begin{array}{c}0.013 \\
(0.019)\end{array}$ & $\begin{array}{l}-0.008 \\
(0.021)\end{array}$ & $\begin{array}{l}-0.024 \\
(0.021)\end{array}$ & $\begin{array}{l}-0.017 \\
(0.024)\end{array}$ & $\begin{array}{c}0.001 \\
(0.025)\end{array}$ & $\begin{array}{l}-0.042 \\
(0.028)\end{array}$ \\
\hline Weekly hours & $\begin{array}{c}-0.006^{* * * *} \\
(0.002)\end{array}$ & $\begin{array}{c}-0.004^{* *} \\
(0.002)\end{array}$ & $\begin{array}{c}-0.004^{* *} \\
(0.002)\end{array}$ & $\begin{array}{c}-0.007^{* * *} \\
(0.002)\end{array}$ & $\begin{array}{c}-0.009^{* * * *} \\
(0.002)\end{array}$ & $\begin{array}{c}-0.008^{* * * *} \\
(0.002)\end{array}$ & $\begin{array}{c}-0.013^{* * * *} \\
(0.002)\end{array}$ & $\begin{array}{c}-0.007^{* * * *} \\
(0.002)\end{array}$ & $\begin{array}{c}-0.005^{* *} \\
(0.002)\end{array}$ & $\begin{array}{c}-0.009^{* * * *} \\
(0.002)\end{array}$ & $\begin{array}{c}-0.010^{* * * *} \\
(0.003)\end{array}$ \\
\hline Education & $\begin{array}{c}0.027^{* * *} \\
(0.009)\end{array}$ & $\begin{array}{l}0.018^{* * *} \\
(0.008)\end{array}$ & $\begin{array}{c}0.038^{* * * *} \\
(0.009)\end{array}$ & $\begin{array}{c}0.050^{* * * *} \\
(0.009)\end{array}$ & $\begin{array}{c}0.059^{* * * *} \\
(0.010)\end{array}$ & $\begin{array}{c}0.036^{* * *} \\
(0.009)\end{array}$ & $\begin{array}{c}0.051^{* * * *} \\
(0.010)\end{array}$ & $\begin{array}{c}0.062^{* * *} \\
(0.010)\end{array}$ & $\begin{array}{c}0.054^{* * * *} \\
(0.011)\end{array}$ & $\begin{array}{c}0.040^{* * * *} \\
(0.012)\end{array}$ & $\begin{array}{c}0.050^{* * * *} \\
(0.013)\end{array}$ \\
\hline Energy and Mining & $\begin{array}{l}0.196^{* *} \\
(0.076)\end{array}$ & $\begin{array}{l}0.147^{* * *} \\
(0.070)\end{array}$ & $\begin{array}{c}0.093 \\
(0.076)\end{array}$ & $\begin{array}{l}-0.003 \\
(0.075)\end{array}$ & $\begin{array}{l}-0.121 \\
(0.081)\end{array}$ & $\begin{array}{c}-0.170^{* *} \\
(0.077)\end{array}$ & $\begin{array}{c}-0.216^{* *} \\
(0.085)\end{array}$ & $\begin{array}{l}-0.144^{*} \\
(0.084)\end{array}$ & $\begin{array}{c}-0.299^{* * * *} \\
(0.095)\end{array}$ & $\begin{array}{c}-0.169^{*} \\
(0.096)\end{array}$ & $\begin{array}{l}-0.175 \\
(0.108)\end{array}$ \\
\hline Engineering & $\begin{array}{l}0.183^{* *} \\
(0.089)\end{array}$ & $\begin{array}{c}0.112 \\
(0.081)\end{array}$ & $\begin{array}{c}0.011 \\
(0.087)\end{array}$ & $\begin{array}{l}0.216^{* * *} \\
(0.092)\end{array}$ & $\begin{array}{c}0.050 \\
(0.097)\end{array}$ & $\begin{array}{c}-0.218^{* *} \\
(0.098)\end{array}$ & $\begin{array}{c}-0.261^{* *} \\
(0.101)\end{array}$ & $\begin{array}{c}0.043 \\
(0.093)\end{array}$ & $\begin{array}{c}0.176 \\
(0.108)\end{array}$ & $\begin{array}{l}-0.013 \\
(0.113)\end{array}$ & $\begin{array}{l}-0.025 \\
(0.125)\end{array}$ \\
\hline Manufacturing & $\begin{array}{l}-0.128 \\
(0.090)\end{array}$ & $\begin{array}{l}-0.062 \\
(0.085)\end{array}$ & $\begin{array}{c}0.074 \\
(0.095)\end{array}$ & $\begin{array}{l}-0.091 \\
(0.092)\end{array}$ & $\begin{array}{l}-0.129 \\
(0.101)\end{array}$ & $\begin{array}{l}-0.050 \\
(0.106)\end{array}$ & $\begin{array}{l}-0.107 \\
(0.109)\end{array}$ & $\begin{array}{c}-0.339^{* * * *} \\
(0.111)\end{array}$ & $\begin{array}{l}-0.188 \\
(0.130)\end{array}$ & $\begin{array}{l}-0.180 \\
(0.126)\end{array}$ & $\begin{array}{l}-0.097 \\
(0.131)\end{array}$ \\
\hline Construction & $\begin{array}{c}0.079 \\
(0.083)\end{array}$ & $\begin{array}{l}-0.023 \\
(0.078)\end{array}$ & $\begin{array}{l}-0.116 \\
(0.089)\end{array}$ & $\begin{array}{l}-0.053 \\
(0.089)\end{array}$ & $\begin{array}{c}-0.265^{* * * *} \\
(0.098)\end{array}$ & $\begin{array}{c}-0.261^{* * * *} \\
(0.094)\end{array}$ & $\begin{array}{c}-0.582^{* * * *} \\
(0.097)\end{array}$ & $\begin{array}{c}-0.281^{* * * *} \\
(0.096)\end{array}$ & $\begin{array}{c}-0.335^{* * * *} \\
(0.108)\end{array}$ & $\begin{array}{c}-0.291^{* * * *} \\
(0.111)\end{array}$ & $\begin{array}{l}-0.205^{*} \\
(0.123)\end{array}$ \\
\hline Sales & $\begin{array}{c}0.045 \\
(0.071)\end{array}$ & $\begin{array}{c}0.096 \\
(0.065)\end{array}$ & $\begin{array}{l}0.127^{*} \\
(0.071)\end{array}$ & $\begin{array}{c}0.033 \\
(0.071)\end{array}$ & $\begin{array}{l}-0.052 \\
(0.075)\end{array}$ & $\begin{array}{l}-0.070 \\
(0.074)\end{array}$ & $\begin{array}{c}-0.156^{* *} \\
(0.079)\end{array}$ & $\begin{array}{l}-0.060 \\
(0.077)\end{array}$ & $\begin{array}{l}-0.073 \\
(0.091)\end{array}$ & $\begin{array}{l}-0.096 \\
(0.095)\end{array}$ & $\begin{array}{l}-0.128 \\
(0.103)\end{array}$ \\
\hline Transport & $\begin{array}{c}0.101 \\
(0.097)\end{array}$ & $\begin{array}{c}0.116 \\
(0.086)\end{array}$ & $\begin{array}{l}0.200^{* * *} \\
(0.094)\end{array}$ & $\begin{array}{c}0.049 \\
(0.092)\end{array}$ & $\begin{array}{l}-0.006 \\
(0.100)\end{array}$ & $\begin{array}{c}-0.224^{* *} \\
(0.105)\end{array}$ & $\begin{array}{c}-0.485^{* * *} \\
(0.111)\end{array}$ & $\begin{array}{l}-0.026 \\
(0.107)\end{array}$ & $\begin{array}{c}-0.448^{* * * *} \\
(0.129)\end{array}$ & $\begin{array}{l}-0.013 \\
(0.138)\end{array}$ & $\begin{array}{c}0.202 \\
(0.185)\end{array}$ \\
\hline Financial & $\begin{array}{l}0.218^{*} \\
(0.121)\end{array}$ & $\begin{array}{c}0.322^{* * * *} \\
(0.115)\end{array}$ & $\begin{array}{c}0.441^{* * * *} \\
(0.126)\end{array}$ & $\begin{array}{c}0.362 * * * \\
(0.127)\end{array}$ & $\begin{array}{l}0.257^{*} \\
(0.134)\end{array}$ & $\begin{array}{l}-0.031 \\
(0.119)\end{array}$ & $\begin{array}{c}0.158 \\
(0.129)\end{array}$ & $\begin{array}{c}0.103 \\
(0.130)\end{array}$ & $\begin{array}{l}-0.027 \\
(0.140)\end{array}$ & $\begin{array}{l}-0.063 \\
(0.146)\end{array}$ & $\begin{array}{c}0.011 \\
(0.151)\end{array}$ \\
\hline Service & $\begin{array}{l}0.126^{*} \\
(0.073)\end{array}$ & $\begin{array}{l}0.162^{* * *} \\
(0.066)\end{array}$ & $\begin{array}{c}0.251^{* * *} \\
(0.072)\end{array}$ & $\begin{array}{c}0.115 \\
(0.071)\end{array}$ & $\begin{array}{c}0.003 \\
(0.078)\end{array}$ & $\begin{array}{l}-0.016 \\
(0.074)\end{array}$ & $\begin{array}{l}-0.066 \\
(0.081)\end{array}$ & $\begin{array}{c}0.026 \\
(0.077)\end{array}$ & $\begin{array}{l}-0.048 \\
(0.089)\end{array}$ & $\begin{array}{l}-0.155^{*} \\
(0.092)\end{array}$ & $\begin{array}{c}-0.249^{* * *} \\
(0.099)\end{array}$ \\
\hline Education & $\begin{array}{c}0.109 \\
(0.090)\end{array}$ & $\begin{array}{l}0.167^{* *} \\
(0.077)\end{array}$ & $\begin{array}{c}0.137 \\
(0.084)\end{array}$ & $\begin{array}{l}-0.055 \\
(0.082)\end{array}$ & $\begin{array}{l}-0.123 \\
(0.087)\end{array}$ & $\begin{array}{l}-0.033 \\
(0.086)\end{array}$ & $\begin{array}{l}-0.086 \\
(0.094)\end{array}$ & $\begin{array}{l}-0.171^{*} \\
(0.090)\end{array}$ & $\begin{array}{c}0.043 \\
(0.106)\end{array}$ & $\begin{array}{c}0.044 \\
(0.107)\end{array}$ & $\begin{array}{c}0.106 \\
(0.114)\end{array}$ \\
\hline Health & $\begin{array}{c}0.032 \\
(0.078)\end{array}$ & $\begin{array}{c}0.055 \\
(0.070)\end{array}$ & $\begin{array}{c}0.090 \\
(0.076)\end{array}$ & $\begin{array}{c}0.035 \\
(0.076)\end{array}$ & $\begin{array}{c}0.010 \\
(0.082)\end{array}$ & $\begin{array}{c}-0.173^{* *} \\
(0.079)\end{array}$ & $\begin{array}{c}-0.211^{* *} \\
(0.084)\end{array}$ & $\begin{array}{l}-0.068 \\
(0.084)\end{array}$ & $\begin{array}{l}-0.075 \\
(0.096)\end{array}$ & $\begin{array}{l}-0.019 \\
(0.099)\end{array}$ & $\begin{array}{l}-0.084 \\
(0.109)\end{array}$ \\
\hline Constant & $27.918^{\text {**** }}$ & $35.149^{* * * *}$ & $29.861^{* * * *}$ & $28.447^{* * * *}$ & $30.017^{\text {*** }}$ & $35.725^{* * * *}$ & $34.451^{* * * *}$ & $49.500^{* * * *}$ & $22.174^{* * *}$ & $37.092^{* * *}$ & $18.870^{* *}$ \\
\hline & & & & & & & & 1,001 & & 1,205 & 970 \\
\hline R-squared & 0.363 & 0.368 & 0.337 & 0.351 & 0.369 & 0.364 & 0.409 & 0.432 & 0.375 & 0.393 & 0.391 \\
\hline
\end{tabular}


Table A.9: Regression Results Full Responsibility - Net Income (1999-2000)

\begin{tabular}{|c|c|c|c|c|c|c|c|c|c|c|}
\hline Variables & 1991 & 1992 & 1993 & 1994 & 1995 & 1996 & 1997 & 1998 & 1999 & 2000 \\
\hline Female & $\begin{array}{c}-0.579^{* * * * *} \\
(0.086)\end{array}$ & $\begin{array}{c}-0.659^{* * * *} \\
(0.095)\end{array}$ & $\begin{array}{c}-0.649^{* * * * *} \\
(0.099)\end{array}$ & $\begin{array}{c}-0.727^{* * * *} \\
(0.102)\end{array}$ & $\begin{array}{c}-0.673^{* * * *} \\
(0.098)\end{array}$ & $\begin{array}{c}-0.570^{* * * *} \\
(0.096)\end{array}$ & $\begin{array}{c}-0.532^{* * * *} \\
(0.094)\end{array}$ & $\begin{array}{c}-0.565^{* * * *} \\
(0.097)\end{array}$ & $\begin{array}{c}-0.720^{* * * *} \\
(0.094)\end{array}$ & $\begin{array}{c}-0.703^{* * * *} \\
(0.070)\end{array}$ \\
\hline Foreign origin & $\begin{array}{c}0.134 \\
(0.105)\end{array}$ & $\begin{array}{c}0.108 \\
(0.125)\end{array}$ & $\begin{array}{c}0.055 \\
(0.132)\end{array}$ & $\begin{array}{c}0.100 \\
(0.136)\end{array}$ & $\begin{array}{l}-0.078 \\
(0.139)\end{array}$ & $\begin{array}{l}-0.124 \\
(0.129)\end{array}$ & $\begin{array}{c}0.042 \\
(0.125)\end{array}$ & $\begin{array}{c}-0.304^{* * *} \\
(0.117)\end{array}$ & $\begin{array}{c}-0.641^{* * * *} \\
(0.114)\end{array}$ & $\begin{array}{c}-0.338^{* * * *} \\
(0.085)\end{array}$ \\
\hline Region (East/ South) & $\begin{array}{c}-0.129^{* * * *} \\
(0.049)\end{array}$ & $\begin{array}{l}-0.295 \\
(0.574)\end{array}$ & $\begin{array}{l}-0.658 \\
(0.411)\end{array}$ & $\begin{array}{c}-0.488^{*} \\
(0.286)\end{array}$ & $\begin{array}{l}-0.283 \\
(0.398)\end{array}$ & $\begin{array}{l}-0.453 \\
(0.283)\end{array}$ & $\begin{array}{l}-0.087 \\
(0.252)\end{array}$ & $\begin{array}{c}-0.106 \\
(0.191)\end{array}$ & $\begin{array}{c}-0.066 \\
(0.186)\end{array}$ & $\begin{array}{c}-0.267^{* *} \\
(0.132)\end{array}$ \\
\hline Secondary & $\begin{array}{l}-0.391 \\
-1.398\end{array}$ & $\begin{array}{l}-0.134 \\
-1.559\end{array}$ & $\begin{array}{l}-0.523 \\
-1.538\end{array}$ & $\begin{array}{c}0.808 \\
-1.239\end{array}$ & $\begin{array}{c}0.275 \\
-1.170\end{array}$ & $\begin{array}{l}-0.542 \\
-1.563\end{array}$ & $\begin{array}{c}0.115 \\
-1.054\end{array}$ & $\begin{array}{l}-0.164 \\
(0.321)\end{array}$ & $\begin{array}{l}-0.326 \\
(0.330)\end{array}$ & $\begin{array}{l}-0.242^{*} \\
(0.140)\end{array}$ \\
\hline Intermediate & $\begin{array}{r}-0.390 \\
-1.400\end{array}$ & $\begin{array}{c}0.089 \\
-1.561\end{array}$ & $\begin{array}{l}-0.430 \\
-1.541\end{array}$ & $\begin{array}{c}0.837 \\
-1.242\end{array}$ & $\begin{array}{r}0.409 \\
-1.173\end{array}$ & $\begin{array}{l}-0.463 \\
-1.564\end{array}$ & $\begin{array}{c}0.252 \\
-1.056\end{array}$ & $\begin{array}{r}-0.093 \\
(0.324)\end{array}$ & $\begin{array}{l}-0.183 \\
(0.332)\end{array}$ & $\begin{array}{l}-0.193 \\
(0.147)\end{array}$ \\
\hline College & $\begin{array}{l}-0.324 \\
-1.401\end{array}$ & $\begin{array}{c}0.172 \\
-1.561\end{array}$ & $\begin{array}{l}-0.340 \\
-1.541\end{array}$ & $\begin{array}{c}0.926 \\
-1.243\end{array}$ & $\begin{array}{c}0.499 \\
-1.173\end{array}$ & $\begin{array}{l}-0.400 \\
-1.565\end{array}$ & $\begin{array}{c}0.269 \\
-1.057\end{array}$ & $\begin{array}{l}-0.178 \\
(0.332)\end{array}$ & $\begin{array}{l}-0.285 \\
(0.339)\end{array}$ & $\begin{array}{l}-0.259^{*} \\
(0.154)\end{array}$ \\
\hline Farmer & $\begin{array}{c}0.146 \\
(0.111)\end{array}$ & $\begin{array}{c}0.147 \\
(0.111)\end{array}$ & $\begin{array}{l}0.223^{*} \\
(0.121)\end{array}$ & $\begin{array}{c}0.166 \\
(0.127)\end{array}$ & $\begin{array}{c}0.040 \\
(0.111)\end{array}$ & $\begin{array}{c}0.039 \\
(0.109)\end{array}$ & $\begin{array}{l}-0.038 \\
(0.108)\end{array}$ & $\begin{array}{c}0.048 \\
(0.107)\end{array}$ & $\begin{array}{l}-0.047 \\
(0.107)\end{array}$ & $\begin{array}{c}0.104 \\
(0.081)\end{array}$ \\
\hline White-collar & $\begin{array}{c}0.084 \\
(0.059)\end{array}$ & $\begin{array}{c}0.014 \\
(0.066)\end{array}$ & $\begin{array}{c}0.014 \\
(0.068)\end{array}$ & $\begin{array}{l}0.133^{*} \\
(0.070)\end{array}$ & $\begin{array}{c}0.072 \\
(0.066)\end{array}$ & $\begin{array}{c}0.092 \\
(0.065)\end{array}$ & $\begin{array}{c}0.050 \\
(0.065)\end{array}$ & $\begin{array}{l}-0.048 \\
(0.063)\end{array}$ & $\begin{array}{c}0.014 \\
(0.061)\end{array}$ & $\begin{array}{c}0.013 \\
(0.048)\end{array}$ \\
\hline Professional & $\begin{array}{c}0.168^{* *} \\
(0.073)\end{array}$ & $\begin{array}{l}-0.097 \\
(0.079)\end{array}$ & $\begin{array}{l}-0.126 \\
(0.085)\end{array}$ & $\begin{array}{l}-0.003 \\
(0.087)\end{array}$ & $\begin{array}{l}-0.047 \\
(0.080)\end{array}$ & $\begin{array}{l}-0.007 \\
(0.079)\end{array}$ & $\begin{array}{l}-0.029 \\
(0.077)\end{array}$ & $\begin{array}{l}-0.023 \\
(0.076)\end{array}$ & $\begin{array}{c}0.041 \\
(0.069)\end{array}$ & $\begin{array}{c}0.162^{* * *} \\
(0.059)\end{array}$ \\
\hline Self-employed & $\begin{array}{l}0.147^{*} \\
(0.075)\end{array}$ & $\begin{array}{c}0.058 \\
(0.088)\end{array}$ & $\begin{array}{c}0.092 \\
(0.093)\end{array}$ & $\begin{array}{c}0.018 \\
(0.094)\end{array}$ & $\begin{array}{c}0.096 \\
(0.092)\end{array}$ & $\begin{array}{c}0.105 \\
(0.091)\end{array}$ & $\begin{array}{c}0.106 \\
(0.093)\end{array}$ & $\begin{array}{c}0.000 \\
(0.093)\end{array}$ & $\begin{array}{l}-0.088 \\
(0.090)\end{array}$ & $\begin{array}{c}0.009 \\
(0.065)\end{array}$ \\
\hline Civil servant & $\begin{array}{c}0.042 \\
(0.079)\end{array}$ & $\begin{array}{l}-0.044 \\
(0.087)\end{array}$ & $\begin{array}{l}0.161^{*} \\
(0.090)\end{array}$ & $\begin{array}{c}0.141 \\
(0.095)\end{array}$ & $\begin{array}{c}0.097 \\
(0.091)\end{array}$ & $\begin{array}{l}-0.017 \\
(0.092)\end{array}$ & $\begin{array}{l}0.148^{*} \\
(0.088)\end{array}$ & $\begin{array}{l}0.154^{*} \\
(0.081)\end{array}$ & $\begin{array}{l}0.156^{*} \\
(0.080)\end{array}$ & $\begin{array}{c}0.163^{* * * *} \\
(0.061)\end{array}$ \\
\hline City & $\begin{array}{c}0.072 \\
(0.045)\end{array}$ & $\begin{array}{c}0.032 \\
(0.050)\end{array}$ & $\begin{array}{c}0.072 \\
(0.054)\end{array}$ & $\begin{array}{c}0.112^{* * *} \\
(0.054)\end{array}$ & $\begin{array}{c}0.122^{* * *} \\
(0.051)\end{array}$ & $\begin{array}{c}0.048 \\
(0.050)\end{array}$ & $\begin{array}{c}0.127^{* *} \\
(0.050)\end{array}$ & $\begin{array}{l}0.095^{*} \\
(0.049)\end{array}$ & $\begin{array}{c}0.056 \\
(0.047)\end{array}$ & $\begin{array}{l}0.063^{*} \\
(0.037)\end{array}$ \\
\hline Large City & $\begin{array}{c}0.055 \\
(0.059)\end{array}$ & $\begin{array}{c}0.092 \\
(0.064)\end{array}$ & $\begin{array}{c}0.094 \\
(0.067)\end{array}$ & $\begin{array}{l}0.142^{* *} \\
(0.069)\end{array}$ & $\begin{array}{l}0.115^{*} \\
(0.066)\end{array}$ & $\begin{array}{c}0.018 \\
(0.064)\end{array}$ & $\begin{array}{l}0.114^{*} \\
(0.062)\end{array}$ & $\begin{array}{c}0.185^{* * * *} \\
(0.063)\end{array}$ & $\begin{array}{l}0.108^{*} \\
(0.061)\end{array}$ & $\begin{array}{c}0.138^{* * * *} \\
(0.048)\end{array}$ \\
\hline birth & $\begin{array}{c}-0.014^{* *} \\
(0.005)\end{array}$ & $\begin{array}{l}-0.011^{*} \\
(0.006)\end{array}$ & $\begin{array}{c}-0.022^{* * * *} \\
(0.006)\end{array}$ & $\begin{array}{c}-0.016^{* *} \\
(0.006)\end{array}$ & $\begin{array}{c}-0.020^{* * *} \\
(0.007)\end{array}$ & $\begin{array}{c}-0.018^{* * *} \\
(0.006)\end{array}$ & $\begin{array}{c}-0.016^{* *} \\
(0.006)\end{array}$ & $\begin{array}{c}-0.015^{* * * *} \\
(0.006)\end{array}$ & $\begin{array}{l}-0.012^{*} \\
(0.006)\end{array}$ & $\begin{array}{c}-0.013^{* * * *} \\
(0.004)\end{array}$ \\
\hline height & $\begin{array}{c}0.007^{* *} \\
(0.003)\end{array}$ & $\begin{array}{l}-0.000 \\
(0.004)\end{array}$ & $\begin{array}{c}0.005 \\
(0.004)\end{array}$ & $\begin{array}{c}0.003 \\
(0.004)\end{array}$ & $\begin{array}{c}0.001 \\
(0.004)\end{array}$ & $\begin{array}{c}0.004 \\
(0.004)\end{array}$ & $\begin{array}{c}0.003 \\
(0.003)\end{array}$ & $\begin{array}{c}0.009^{* * * *} \\
(0.004)\end{array}$ & $\begin{array}{l}0.006^{*} \\
(0.003)\end{array}$ & $\begin{array}{c}0.003 \\
(0.002)\end{array}$ \\
\hline Partner Variables & & & & & & & & & & \\
\hline Region (East / South) & & $\begin{array}{c}0.262 \\
(0.574)\end{array}$ & $\begin{array}{l}0.709^{*} \\
(0.412)\end{array}$ & $\begin{array}{c}0.428 \\
(0.288)\end{array}$ & $\begin{array}{c}0.196 \\
(0.398)\end{array}$ & $\begin{array}{c}0.354 \\
(0.284)\end{array}$ & $\begin{array}{c}0.049 \\
(0.253)\end{array}$ & $\begin{array}{c}0.166 \\
(0.193)\end{array}$ & $\begin{array}{c}-0.068 \\
(0.187)\end{array}$ & $\begin{array}{c}0.180 \\
(0.132)\end{array}$ \\
\hline Foreign origin & $\begin{array}{l}-0.018 \\
(0.111)\end{array}$ & $\begin{array}{c}0.087 \\
(0.130)\end{array}$ & $\begin{array}{l}-0.076 \\
(0.139)\end{array}$ & $\begin{array}{l}-0.001 \\
(0.143)\end{array}$ & $\begin{array}{c}0.049 \\
(0.147)\end{array}$ & $\begin{array}{c}0.125 \\
(0.135)\end{array}$ & $\begin{array}{c}0.037 \\
(0.129)\end{array}$ & $\begin{array}{l}-0.060 \\
(0.124)\end{array}$ & $\begin{array}{l}-0.080 \\
(0.124)\end{array}$ & $\begin{array}{l}-0.060 \\
(0.087)\end{array}$ \\
\hline Secondary & $\begin{array}{l}-0.859 \\
-1.445\end{array}$ & $\begin{array}{l}-0.795 \\
-1.610\end{array}$ & $\begin{array}{l}-1.003 \\
-1.598\end{array}$ & $\begin{array}{c}0.303 \\
-1.247\end{array}$ & $\begin{array}{l}-0.580 \\
-1.178\end{array}$ & $\begin{array}{l}-1.282 \\
-1.640\end{array}$ & $\begin{array}{l}-0.725 \\
-1.059\end{array}$ & $\begin{array}{c}-0.636^{*} \\
(0.336)\end{array}$ & $\begin{array}{l}-0.579^{*} \\
(0.336)\end{array}$ & $\begin{array}{l}-0.123 \\
(0.140)\end{array}$ \\
\hline Intermediate & -0.920 & -0.704 & -1.095 & 0.322 & -0.646 & -1.246 & -0.763 & $-0.825^{* *}$ & $-0.715^{* *}$ & -0.118 \\
\hline & -1.447 & -1.613 & -1.601 & -1.250 & -1.181 & -1.642 & -1.062 & $(0.339)$ & $(0.338)$ & $(0.147)$ \\
\hline College & $\begin{array}{l}-0.774 \\
-1.448\end{array}$ & $\begin{array}{l}-0.773 \\
-1.614\end{array}$ & $\begin{array}{l}-1.246 \\
-1.602\end{array}$ & $\begin{array}{c}0.312 \\
-1.251\end{array}$ & $\begin{array}{l}-0.660 \\
-1.182\end{array}$ & $\begin{array}{l}-1.336 \\
-1.643\end{array}$ & $\begin{array}{l}-0.742 \\
-1.063\end{array}$ & $\begin{array}{l}-0.675^{*} \\
(0.345)\end{array}$ & $\begin{array}{c}-0.788^{* *} \\
(0.344)\end{array}$ & $\begin{array}{l}-0.238 \\
(0.153)\end{array}$ \\
\hline Farmer & $\begin{array}{c}0.115 \\
(0.110)\end{array}$ & $\begin{array}{l}-0.031 \\
(0.111)\end{array}$ & $\begin{array}{l}-0.012 \\
(0.123)\end{array}$ & $\begin{array}{c}0.121 \\
(0.131)\end{array}$ & $\begin{array}{c}0.086 \\
(0.112)\end{array}$ & $\begin{array}{c}0.046 \\
(0.112)\end{array}$ & $\begin{array}{l}-0.047 \\
(0.108)\end{array}$ & $\begin{array}{l}-0.171 \\
(0.107)\end{array}$ & $\begin{array}{c}-0.304^{* * * *} \\
(0.107)\end{array}$ & $\begin{array}{l}-0.097 \\
(0.081)\end{array}$ \\
\hline White-Collor & $\begin{array}{c}0.061 \\
(0.059)\end{array}$ & $\begin{array}{c}0.003 \\
(0.066)\end{array}$ & $\begin{array}{c}0.019 \\
(0.068)\end{array}$ & $\begin{array}{c}0.112 \\
(0.069)\end{array}$ & $\begin{array}{c}0.092 \\
(0.066)\end{array}$ & $\begin{array}{c}0.003 \\
(0.065)\end{array}$ & $\begin{array}{l}0.117^{*} \\
(0.064)\end{array}$ & $\begin{array}{c}0.093 \\
(0.063)\end{array}$ & $\begin{array}{l}0.122^{* *} \\
(0.061)\end{array}$ & $\begin{array}{c}0.044 \\
(0.048)\end{array}$ \\
\hline Professional & $\begin{array}{c}0.156^{* *} \\
(0.072)\end{array}$ & $\begin{array}{c}0.030 \\
(0.080)\end{array}$ & $\begin{array}{c}0.136 \\
(0.086)\end{array}$ & $\begin{array}{c}0.111 \\
(0.086)\end{array}$ & $\begin{array}{c}0.051 \\
(0.080)\end{array}$ & $\begin{array}{l}-0.053 \\
(0.078)\end{array}$ & $\begin{array}{c}0.102 \\
(0.076)\end{array}$ & $\begin{array}{c}0.153^{* *} \\
(0.076)\end{array}$ & $\begin{array}{c}0.203^{* * *} \\
(0.069)\end{array}$ & $\begin{array}{c}0.082 \\
(0.060)\end{array}$ \\
\hline Self-employed & $\begin{array}{l}0.165^{* *} \\
(0.073)\end{array}$ & $\begin{array}{c}0.006 \\
(0.087)\end{array}$ & $\begin{array}{l}0.166^{*} \\
(0.092)\end{array}$ & $\begin{array}{l}0.151^{*} \\
(0.092)\end{array}$ & $\begin{array}{l}0.166^{*} \\
(0.092)\end{array}$ & $\begin{array}{l}-0.081 \\
(0.091)\end{array}$ & $\begin{array}{c}0.071 \\
(0.092)\end{array}$ & $\begin{array}{c}0.097 \\
(0.092)\end{array}$ & $\begin{array}{c}0.013 \\
(0.089)\end{array}$ & $\begin{array}{c}0.003 \\
(0.066)\end{array}$ \\
\hline Civil Servant & $\begin{array}{c}0.058 \\
(0.078)\end{array}$ & $\begin{array}{c}0.010 \\
(0.086)\end{array}$ & $\begin{array}{l}0.204^{* * *} \\
(0.090)\end{array}$ & $\begin{array}{c}0.047 \\
(0.095)\end{array}$ & $\begin{array}{l}0.174^{*} \\
(0.091)\end{array}$ & $\begin{array}{c}0.074 \\
(0.092)\end{array}$ & $\begin{array}{l}0.177^{* * *} \\
(0.088)\end{array}$ & $\begin{array}{l}-0.082 \\
(0.082)\end{array}$ & $\begin{array}{c}0.048 \\
(0.080)\end{array}$ & $\begin{array}{c}0.130^{* *} \\
(0.061)\end{array}$ \\
\hline City & $\begin{array}{c}0.068 \\
(0.045)\end{array}$ & $\begin{array}{l}-0.025 \\
(0.050)\end{array}$ & $\begin{array}{c}0.024 \\
(0.053)\end{array}$ & $\begin{array}{c}0.006 \\
(0.054)\end{array}$ & $\begin{array}{c}0.041 \\
(0.052)\end{array}$ & $\begin{array}{c}0.017 \\
(0.050)\end{array}$ & $\begin{array}{l}-0.017 \\
(0.050)\end{array}$ & $\begin{array}{l}-0.070 \\
(0.050)\end{array}$ & $\begin{array}{c}0.033 \\
(0.047)\end{array}$ & $\begin{array}{c}0.052 \\
(0.037)\end{array}$ \\
\hline Large City & $\begin{array}{l}0.102^{*} \\
(0.059)\end{array}$ & $\begin{array}{c}0.036 \\
(0.064)\end{array}$ & $\begin{array}{c}0.070 \\
(0.067)\end{array}$ & $\begin{array}{c}0.029 \\
(0.069)\end{array}$ & $\begin{array}{c}0.061 \\
(0.066)\end{array}$ & $\begin{array}{c}0.058 \\
(0.064)\end{array}$ & $\begin{array}{c}0.037 \\
(0.062)\end{array}$ & $\begin{array}{l}-0.050 \\
(0.064)\end{array}$ & $\begin{array}{c}0.025 \\
(0.061)\end{array}$ & $\begin{array}{c}0.021 \\
(0.048)\end{array}$ \\
\hline birth & $\begin{array}{c}0.006 \\
(0.005)\end{array}$ & $\begin{array}{c}0.001 \\
(0.006)\end{array}$ & $\begin{array}{l}0.011^{*} \\
(0.006)\end{array}$ & $\begin{array}{c}0.004 \\
(0.006)\end{array}$ & $\begin{array}{l}0.013^{* * *} \\
(0.007)\end{array}$ & $\begin{array}{c}0.005 \\
(0.006)\end{array}$ & $\begin{array}{c}0.002 \\
(0.006)\end{array}$ & $\begin{array}{l}-0.003 \\
(0.006)\end{array}$ & $\begin{array}{l}-0.001 \\
(0.006)\end{array}$ & $\begin{array}{l}-0.002 \\
(0.004)\end{array}$ \\
\hline height & $\begin{array}{c}0.001 \\
(0.003)\end{array}$ & $\begin{array}{c}0.001 \\
(0.004)\end{array}$ & $\begin{array}{c}0.004 \\
(0.004)\end{array}$ & $\begin{array}{c}0.004 \\
(0.004)\end{array}$ & $\begin{array}{l}-0.001 \\
(0.004)\end{array}$ & $\begin{array}{c}0.001 \\
(0.004)\end{array}$ & $\begin{array}{c}0.002 \\
(0.003)\end{array}$ & $\begin{array}{c}0.003 \\
(0.004)\end{array}$ & $\begin{array}{l}0.009^{* *} \\
(0.003)\end{array}$ & $\begin{array}{l}0.005^{*} \\
(0.002)\end{array}$ \\
\hline Experience & $\begin{array}{l}-0.051^{*} \\
(0.027)\end{array}$ & $\begin{array}{l}-0.038 \\
(0.031)\end{array}$ & $\begin{array}{l}-0.039 \\
(0.033)\end{array}$ & $\begin{array}{l}-0.059^{*} \\
(0.034)\end{array}$ & $\begin{array}{l}-0.003 \\
(0.034)\end{array}$ & $\begin{array}{l}-0.030 \\
(0.034)\end{array}$ & $\begin{array}{l}-0.058^{*} \\
(0.034)\end{array}$ & $\begin{array}{l}-0.010 \\
(0.034)\end{array}$ & $\begin{array}{l}-0.057^{*} \\
(0.033)\end{array}$ & $\begin{array}{l}-0.030 \\
(0.024)\end{array}$ \\
\hline Sq experience & $\begin{array}{l}-0.018 \\
(0.018)\end{array}$ & $\begin{array}{l}-0.032 \\
(0.021)\end{array}$ & $\begin{array}{l}-0.009 \\
(0.021)\end{array}$ & $\begin{array}{c}0.011 \\
(0.023)\end{array}$ & $\begin{array}{c}0.005 \\
(0.023)\end{array}$ & $\begin{array}{l}-0.014 \\
(0.023)\end{array}$ & $\begin{array}{l}-0.001 \\
(0.023)\end{array}$ & $\begin{array}{c}0.015 \\
(0.021)\end{array}$ & $\begin{array}{l}-0.013 \\
(0.020)\end{array}$ & $\begin{array}{l}-0.019 \\
(0.015)\end{array}$ \\
\hline weekly hours & $\begin{array}{c}0.000 \\
(0.002)\end{array}$ & $\begin{array}{l}-0.004 \\
(0.002)\end{array}$ & $\begin{array}{c}-0.006^{* *} \\
(0.003)\end{array}$ & $\begin{array}{c}0.003 \\
(0.002)\end{array}$ & $\begin{array}{l}0.005^{* *} \\
(0.002)\end{array}$ & $\begin{array}{c}0.001 \\
(0.002)\end{array}$ & $\begin{array}{c}0.000 \\
(0.002)\end{array}$ & $\begin{array}{l}-0.004^{*} \\
(0.002)\end{array}$ & $\begin{array}{l}0.004 * * \\
(0.002)\end{array}$ & $\begin{array}{c}0.002 \\
(0.002)\end{array}$ \\
\hline education & $\begin{array}{l}-0.004 \\
(0.011)\end{array}$ & $\begin{array}{c}0.001 \\
(0.012)\end{array}$ & $\begin{array}{c}0.013 \\
(0.013)\end{array}$ & $\begin{array}{l}0.027^{* *} \\
(0.012)\end{array}$ & $\begin{array}{l}0.021^{*} \\
(0.012)\end{array}$ & $\begin{array}{c}0.036^{* * *} \\
(0.011)\end{array}$ & $\begin{array}{c}0.016 \\
(0.011)\end{array}$ & $\begin{array}{l}0.026^{* *} \\
(0.011)\end{array}$ & $\begin{array}{c}0.051^{* * *} \\
(0.010)\end{array}$ & $\begin{array}{c}0.038^{* * * *} \\
(0.008)\end{array}$ \\
\hline Energy and Minig & $\begin{array}{l}-0.150^{*} \\
(0.077)\end{array}$ & $\begin{array}{l}-0.047 \\
(0.084)\end{array}$ & $\begin{array}{l}-0.086 \\
(0.089)\end{array}$ & $\begin{array}{c}-0.196^{* *} \\
(0.093)\end{array}$ & $\begin{array}{l}-0.143 \\
(0.087)\end{array}$ & $\begin{array}{l}-0.163^{*} \\
(0.088)\end{array}$ & $\begin{array}{l}-0.079 \\
(0.088)\end{array}$ & $\begin{array}{l}-0.106 \\
(0.087)\end{array}$ & $\begin{array}{l}-0.115 \\
(0.086)\end{array}$ & $\begin{array}{l}-0.001 \\
(0.065)\end{array}$ \\
\hline Engineering & $\begin{array}{l}-0.164^{*} \\
(0.091)\end{array}$ & $\begin{array}{l}-0.178^{*} \\
(0.104)\end{array}$ & $\begin{array}{l}-0.110 \\
(0.110)\end{array}$ & $\begin{array}{l}-0.101 \\
(0.105)\end{array}$ & $\begin{array}{l}-0.104 \\
(0.101)\end{array}$ & $\begin{array}{l}-0.168 \\
(0.107)\end{array}$ & $\begin{array}{l}-0.176^{*} \\
(0.105)\end{array}$ & $\begin{array}{c}0.044 \\
(0.106)\end{array}$ & $\begin{array}{l}-0.140 \\
(0.097)\end{array}$ & $\begin{array}{c}0.006 \\
(0.076)\end{array}$ \\
\hline Manufacturing & $\begin{array}{l}-0.019 \\
(0.094)\end{array}$ & $\begin{array}{c}0.023 \\
(0.109)\end{array}$ & $\begin{array}{l}-0.037 \\
(0.114)\end{array}$ & $\begin{array}{l}-0.156 \\
(0.116)\end{array}$ & $\begin{array}{l}-0.159 \\
(0.114)\end{array}$ & $\begin{array}{l}-0.064 \\
(0.112)\end{array}$ & $\begin{array}{c}-0.284^{* * *} \\
(0.109)\end{array}$ & $\begin{array}{c}0.123 \\
(0.109)\end{array}$ & $\begin{array}{l}-0.005 \\
(0.109)\end{array}$ & $\begin{array}{l}-0.063 \\
(0.080)\end{array}$ \\
\hline Construction & $\begin{array}{l}-0.022 \\
(0.092)\end{array}$ & $\begin{array}{l}-0.051 \\
(0.100)\end{array}$ & $\begin{array}{l}-0.105 \\
(0.105)\end{array}$ & $\begin{array}{c}-0.244^{* *} \\
(0.103)\end{array}$ & $\begin{array}{l}-0.038 \\
(0.100)\end{array}$ & $\begin{array}{l}-0.158 \\
(0.097)\end{array}$ & $\begin{array}{l}-0.027 \\
(0.103)\end{array}$ & $\begin{array}{l}-0.077 \\
(0.107)\end{array}$ & $\begin{array}{l}-0.027 \\
(0.097)\end{array}$ & $\begin{array}{l}-0.003 \\
(0.074)\end{array}$ \\
\hline Sales & $\begin{array}{c}-0.155^{* *} \\
(0.079)\end{array}$ & $\begin{array}{l}-0.145^{*} \\
(0.086)\end{array}$ & $\begin{array}{c}-0.211^{* *} \\
(0.091)\end{array}$ & $\begin{array}{l}-0.170^{*} \\
(0.091)\end{array}$ & $\begin{array}{c}-0.185^{* *} \\
(0.087)\end{array}$ & $\begin{array}{c}-0.185^{* *} \\
(0.088)\end{array}$ & $\begin{array}{c}-0.240^{* * *} \\
(0.087)\end{array}$ & $\begin{array}{l}-0.063 \\
(0.086)\end{array}$ & $\begin{array}{c}-0.199^{* *} \\
(0.085)\end{array}$ & $\begin{array}{c}-0.134^{* *} \\
(0.063)\end{array}$ \\
\hline Transport & $\begin{array}{l}-0.168 \\
(0.105)\end{array}$ & $\begin{array}{c}-0.235^{* * *} \\
(0.114)\end{array}$ & $\begin{array}{l}-0.128 \\
(0.126)\end{array}$ & $\begin{array}{l}-0.211^{*} \\
(0.125)\end{array}$ & $\begin{array}{c}-0.370^{* * *} \\
(0.124)\end{array}$ & $\begin{array}{l}-0.197^{*} \\
(0.119)\end{array}$ & $\begin{array}{l}-0.054 \\
(0.120)\end{array}$ & $\begin{array}{l}-0.160 \\
(0.121)\end{array}$ & $\begin{array}{c}-0.286^{* *} \\
(0.117)\end{array}$ & $\begin{array}{l}-0.094 \\
(0.084)\end{array}$ \\
\hline Financial & $\begin{array}{c}0.061 \\
(0.118)\end{array}$ & $\begin{array}{c}0.101 \\
(0.129)\end{array}$ & $\begin{array}{c}0.050 \\
(0.134)\end{array}$ & $\begin{array}{l}-0.015 \\
(0.133)\end{array}$ & $\begin{array}{c}0.080 \\
(0.130)\end{array}$ & $\begin{array}{l}0.241^{*} \\
(0.135)\end{array}$ & $\begin{array}{l}0.247^{*} \\
(0.134)\end{array}$ & $\begin{array}{c}0.350^{* * * *} \\
(0.127)\end{array}$ & $\begin{array}{c}0.039 \\
(0.128)\end{array}$ & $\begin{array}{c}0.066 \\
(0.112)\end{array}$ \\
\hline Service & $\begin{array}{l}-0.060 \\
(0.092)\end{array}$ & $\begin{array}{l}-0.010 \\
(0.095)\end{array}$ & $\begin{array}{l}-0.043 \\
(0.098)\end{array}$ & $\begin{array}{c}-0.302^{* * *} \\
(0.097)\end{array}$ & $\begin{array}{l}-0.028 \\
(0.095)\end{array}$ & $\begin{array}{l}-0.008 \\
(0.096)\end{array}$ & $\begin{array}{c}0.015 \\
(0.089)\end{array}$ & $\begin{array}{l}0.184^{* *} \\
(0.087)\end{array}$ & $\begin{array}{c}0.088 \\
(0.082)\end{array}$ & $\begin{array}{l}-0.002 \\
(0.062)\end{array}$ \\
\hline Education & $\begin{array}{c}0.052 \\
(0.097)\end{array}$ & $\begin{array}{c}0.071 \\
(0.102)\end{array}$ & $\begin{array}{l}-0.144 \\
(0.104)\end{array}$ & $\begin{array}{l}-0.155 \\
(0.102)\end{array}$ & $\begin{array}{c}0.088 \\
(0.100)\end{array}$ & $\begin{array}{c}0.122 \\
(0.103)\end{array}$ & $\begin{array}{c}0.109 \\
(0.105)\end{array}$ & $\begin{array}{c}0.077 \\
(0.101)\end{array}$ & $\begin{array}{l}-0.140 \\
(0.098)\end{array}$ & $\begin{array}{c}0.012 \\
(0.073)\end{array}$ \\
\hline Health & $\begin{array}{l}-0.128 \\
(0.090)\end{array}$ & $\begin{array}{l}-0.172^{*} \\
(0.093)\end{array}$ & $\begin{array}{l}-0.160 \\
(0.099)\end{array}$ & $\begin{array}{l}-0.161 \\
(0.102)\end{array}$ & $\begin{array}{l}-0.138 \\
(0.095)\end{array}$ & $\begin{array}{l}-0.110 \\
(0.092)\end{array}$ & $\begin{array}{c}-0.234^{* * * *} \\
(0.089)\end{array}$ & $\begin{array}{l}-0.017 \\
(0.088)\end{array}$ & $\begin{array}{l}-0.116 \\
(0.088)\end{array}$ & $\begin{array}{c}0.054 \\
(0.068)\end{array}$ \\
\hline Income & $\begin{array}{c}-0.229^{* * * *} \\
(0.039)\end{array}$ & $\begin{array}{c}-0.256^{* * * *} \\
(0.037)\end{array}$ & $\begin{array}{c}-0.180^{* * * *} \\
(0.039)\end{array}$ & $\begin{array}{c}-0.239^{* * * *} \\
(0.038)\end{array}$ & $\begin{array}{c}-0.313^{* * * *} \\
(0.039)\end{array}$ & $\begin{array}{c}-0.337^{* * *} \\
(0.037)\end{array}$ & $\begin{array}{c}-0.372^{* * *} \\
(0.036)\end{array}$ & $\begin{array}{c}-0.230^{* * * *} \\
(0.034)\end{array}$ & $\begin{array}{c}-0.321^{* * * *} \\
(0.037)\end{array}$ & $\begin{array}{c}-0.344^{* * * *} \\
(0.027)\end{array}$ \\
\hline Constant & $27.483^{* * * *}$ & $31.997^{* * * *}$ & $32.922^{* * *}$ & $31.999^{* * * *}$ & $26.791^{* * * *}$ & $39.660^{* * *}$ & $39.645^{* * *}$ & $46.545^{* * * *}$ & $35.399^{* * * *}$ & $42.735^{* * * *}$ \\
\hline & -5.563 & -6.412 & -6.898 & -6.945 & -6.646 & -6.906 & -6.739 & -6.775 & -6.274 & -4.797 \\
\hline $\mathrm{Ob}$ & 1,182 & 1,162 & 1,13 & 1,124 & 1,124 & 1,092 & 1,076 & 1,202 & 1,21 & 2,146 \\
\hline ed & 0.433 & 414 & 0.409 & 0.396 & 0.429 & 0.447 & 0.452 & 0.439 & 0.455 & 0.443 \\
\hline
\end{tabular}


Table A.10: Regression Results Full Responsibility - Net Income (2001-2011)

\begin{tabular}{|c|c|c|c|c|c|c|c|c|c|c|c|}
\hline Variables & 2001 & 2002 & 2003 & 2004 & 2005 & 2006 & 2007 & 2008 & 2009 & 2010 & 2011 \\
\hline Female & $\begin{array}{c}-0.799^{* * * *} \\
(0.071)\end{array}$ & $\begin{array}{c}-0.720^{* * * *} \\
(0.065)\end{array}$ & $\begin{array}{c}-0.621^{* * * *} \\
(0.066)\end{array}$ & $\begin{array}{c}-0.722^{* * *} \\
(0.070)\end{array}$ & $\begin{array}{c}-0.613^{* * *} \\
(0.074)\end{array}$ & $\begin{array}{c}-0.489^{* * *} \\
(0.070)\end{array}$ & $\begin{array}{c}-0.579^{* * *} \\
(0.074)\end{array}$ & $\begin{array}{c}-0.574^{* * *} \\
(0.076)\end{array}$ & $\begin{array}{c}-0.584^{* * *} \\
(0.087)\end{array}$ & $\begin{array}{c}-0.585^{* * * *} \\
(0.090)\end{array}$ & $\begin{array}{c}-0.505^{* * *} \\
(0.099)\end{array}$ \\
\hline Foreign origin & $\begin{array}{c}-0.265^{* * * *} \\
(0.077)\end{array}$ & $\begin{array}{c}-0.218^{* * * *} \\
(0.067)\end{array}$ & $\begin{array}{c}-0.136^{*} \\
(0.071)\end{array}$ & $\begin{array}{c}-0.137^{*} \\
(0.075)\end{array}$ & $\begin{array}{c}-0.186^{* * *} \\
(0.072)\end{array}$ & $\begin{array}{c}-0.262^{* * * *} \\
(0.065)\end{array}$ & $\begin{array}{c}-0.225^{* * *} \\
(0.072)\end{array}$ & $\begin{array}{c}-0.318^{* * *} \\
(0.073)\end{array}$ & $\begin{array}{c}-0.322^{* * *} \\
(0.084)\end{array}$ & $\begin{array}{c}-0.448^{* * * *} \\
(0.086)\end{array}$ & $\begin{array}{c}-0.274^{* *} \\
(0.109)\end{array}$ \\
\hline Region (East/ South) & $\begin{array}{l}-0.192 \\
(0.125)\end{array}$ & $\begin{array}{l}-0.145 \\
(0.127)\end{array}$ & $\begin{array}{l}-0.064 \\
(0.159)\end{array}$ & $\begin{array}{c}0.156 \\
(0.150)\end{array}$ & $\begin{array}{l}-0.026 \\
(0.157)\end{array}$ & $\begin{array}{c}0.058 \\
(0.145)\end{array}$ & $\begin{array}{c}0.137 \\
(0.148)\end{array}$ & $\begin{array}{c}-0.582^{* * * *} \\
(0.148)\end{array}$ & $\begin{array}{l}-0.231 \\
(0.158)\end{array}$ & $\begin{array}{l}-0.304^{*} \\
(0.155)\end{array}$ & $\begin{array}{l}-0.177 \\
(0.252)\end{array}$ \\
\hline Secondary & $\begin{array}{c}-0.303^{* *} \\
(0.132)\end{array}$ & $\begin{array}{l}-0.019 \\
(0.113)\end{array}$ & $\begin{array}{l}-0.008 \\
(0.103)\end{array}$ & $\begin{array}{c}0.028 \\
(0.109)\end{array}$ & $\begin{array}{l}-0.000 \\
(0.102)\end{array}$ & $\begin{array}{l}-0.107 \\
(0.094)\end{array}$ & $\begin{array}{c}-0.324^{* * *} \\
(0.095)\end{array}$ & $\begin{array}{c}-0.420^{* * * *} \\
(0.098)\end{array}$ & $\begin{array}{c}-0.578^{* * * *} \\
(0.116)\end{array}$ & $\begin{array}{c}-0.375^{* * *} \\
(0.129)\end{array}$ & $\begin{array}{c}-0.548^{* * * *} \\
(0.140)\end{array}$ \\
\hline Intermediate & $\begin{array}{c}-0.334^{* *} \\
(0.140)\end{array}$ & $\begin{array}{l}-0.120 \\
(0.119)\end{array}$ & $\begin{array}{l}-0.107 \\
(0.111)\end{array}$ & $\begin{array}{l}-0.105 \\
(0.114)\end{array}$ & $\begin{array}{l}-0.197^{*} \\
(0.110)\end{array}$ & $\begin{array}{c}-0.356^{* * * *} \\
(0.104)\end{array}$ & $\begin{array}{c}-0.324^{* * *} \\
(0.107)\end{array}$ & $\begin{array}{c}-0.433^{* * *} \\
(0.109)\end{array}$ & $\begin{array}{c}-0.657^{* * * *} \\
(0.126)\end{array}$ & $\begin{array}{c}-0.408^{* * * *} \\
(0.138)\end{array}$ & $\begin{array}{c}-0.524^{* * *} \\
(0.152)\end{array}$ \\
\hline College & $\begin{array}{l}-0.263^{*} \\
(0.147)\end{array}$ & $\begin{array}{c}0.084 \\
(0.127)\end{array}$ & $\begin{array}{c}0.071 \\
(0.119)\end{array}$ & $\begin{array}{l}-0.020 \\
(0.123)\end{array}$ & $\begin{array}{l}-0.081 \\
(0.121)\end{array}$ & $\begin{array}{l}-0.157 \\
(0.112)\end{array}$ & $\begin{array}{c}-0.259^{* *} \\
(0.115)\end{array}$ & $\begin{array}{c}-0.435^{* * *} \\
(0.115)\end{array}$ & $\begin{array}{c}-0.469^{* * *} \\
(0.136)\end{array}$ & $\begin{array}{l}-0.264^{*} \\
(0.148)\end{array}$ & $\begin{array}{c}-0.438^{* * * *} \\
(0.161)\end{array}$ \\
\hline Farmer & $\begin{array}{c}0.025 \\
(0.086)\end{array}$ & $\begin{array}{l}-0.067 \\
(0.076)\end{array}$ & $\begin{array}{c}0.018 \\
(0.081)\end{array}$ & $\begin{array}{l}-0.077 \\
(0.085)\end{array}$ & $\begin{array}{c}0.003 \\
(0.087)\end{array}$ & $\begin{array}{l}-0.007 \\
(0.084)\end{array}$ & $\begin{array}{c}0.101 \\
(0.086)\end{array}$ & $\begin{array}{l}-0.018 \\
(0.093)\end{array}$ & $\begin{array}{c}0.018 \\
(0.101)\end{array}$ & $\begin{array}{c}-0.303^{* * * *} \\
(0.110)\end{array}$ & $\begin{array}{c}0.136 \\
(0.121)\end{array}$ \\
\hline White-collar & $\begin{array}{l}-0.062 \\
(0.049)\end{array}$ & $\begin{array}{l}-0.019 \\
(0.044)\end{array}$ & $\begin{array}{c}0.025 \\
(0.047)\end{array}$ & $\begin{array}{l}-0.071 \\
(0.049)\end{array}$ & $\begin{array}{l}-0.036 \\
(0.052)\end{array}$ & $\begin{array}{c}0.047 \\
(0.049)\end{array}$ & $\begin{array}{l}-0.016 \\
(0.052)\end{array}$ & $\begin{array}{c}0.025 \\
(0.052)\end{array}$ & $\begin{array}{c}0.065 \\
(0.060)\end{array}$ & $\begin{array}{l}-0.049 \\
(0.059)\end{array}$ & $\begin{array}{c}-0.168^{* *} \\
(0.068)\end{array}$ \\
\hline Professional & $\begin{array}{l}0.133^{* *} \\
(0.061)\end{array}$ & $\begin{array}{c}0.163^{* * * *} \\
(0.056)\end{array}$ & $\begin{array}{l}0.114^{*} \\
(0.059)\end{array}$ & $\begin{array}{c}0.245^{* * * *} \\
(0.059)\end{array}$ & $\begin{array}{c}0.185^{* * * *} \\
(0.060)\end{array}$ & $\begin{array}{c}0.239^{* * * *} \\
(0.059)\end{array}$ & $\begin{array}{c}0.164^{* *} \\
(0.064)\end{array}$ & $\begin{array}{c}0.075 \\
(0.064)\end{array}$ & $\begin{array}{l}0.176^{* *} \\
(0.072)\end{array}$ & $\begin{array}{l}0.195^{* * *} \\
(0.076)\end{array}$ & $\begin{array}{c}0.039 \\
(0.082)\end{array}$ \\
\hline Self-employed & $\begin{array}{l}-0.082 \\
(0.067)\end{array}$ & $\begin{array}{l}-0.081 \\
(0.058)\end{array}$ & $\begin{array}{c}-0.142^{* * *} \\
(0.062)\end{array}$ & $\begin{array}{l}-0.061 \\
(0.064)\end{array}$ & $\begin{array}{c}0.107 \\
(0.071)\end{array}$ & $\begin{array}{c}0.046 \\
(0.066)\end{array}$ & $\begin{array}{l}-0.037 \\
(0.070)\end{array}$ & $\begin{array}{l}-0.012 \\
(0.066)\end{array}$ & $\begin{array}{c}0.082 \\
(0.079)\end{array}$ & $\begin{array}{l}0.187^{* * *} \\
(0.083)\end{array}$ & $\begin{array}{l}-0.035 \\
(0.095)\end{array}$ \\
\hline Civil servant & $\begin{array}{c}0.288^{* * * *} \\
(0.067)\end{array}$ & $\begin{array}{c}0.197^{* * * *} \\
(0.060)\end{array}$ & $\begin{array}{l}0.104^{*} \\
(0.062)\end{array}$ & $\begin{array}{l}0.112^{*} \\
(0.062)\end{array}$ & $\begin{array}{c}0.152^{* * *} \\
(0.066)\end{array}$ & $\begin{array}{c}0.206^{* * * *} \\
(0.064)\end{array}$ & $\begin{array}{c}0.099 \\
(0.068)\end{array}$ & $\begin{array}{c}0.245^{* * *} \\
(0.070)\end{array}$ & $\begin{array}{c}0.092 \\
(0.079)\end{array}$ & $\begin{array}{c}0.248^{* * * *} \\
(0.084)\end{array}$ & $\begin{array}{c}0.138 \\
(0.090)\end{array}$ \\
\hline City & $\begin{array}{c}0.016 \\
(0.037)\end{array}$ & $\begin{array}{c}0.043 \\
(0.035)\end{array}$ & $\begin{array}{c}0.010 \\
(0.036)\end{array}$ & $\begin{array}{c}0.049 \\
(0.037)\end{array}$ & $\begin{array}{c}0.103^{* * *} \\
(0.039)\end{array}$ & $\begin{array}{c}0.033 \\
(0.038)\end{array}$ & $\begin{array}{c}0.004 \\
(0.041)\end{array}$ & $\begin{array}{l}-0.005 \\
(0.040)\end{array}$ & $\begin{array}{c}0.018 \\
(0.046)\end{array}$ & $\begin{array}{c}0.030 \\
(0.046)\end{array}$ & $\begin{array}{c}0.014 \\
(0.053)\end{array}$ \\
\hline Large City & $\begin{array}{c}0.071 \\
(0.049)\end{array}$ & $\begin{array}{c}0.072 \\
(0.046)\end{array}$ & $\begin{array}{c}0.124^{* * * *} \\
(0.048)\end{array}$ & $\begin{array}{l}0.086^{*} \\
(0.048)\end{array}$ & $\begin{array}{c}0.066 \\
(0.048)\end{array}$ & $\begin{array}{c}0.042 \\
(0.048)\end{array}$ & $\begin{array}{l}-0.018 \\
(0.051)\end{array}$ & $\begin{array}{c}0.023 \\
(0.053)\end{array}$ & $\begin{array}{c}0.011 \\
(0.061)\end{array}$ & $\begin{array}{l}-0.004 \\
(0.063)\end{array}$ & $\begin{array}{c}0.100 \\
(0.070)\end{array}$ \\
\hline birth & $\begin{array}{c}-0.010^{* *} \\
(0.005)\end{array}$ & $\begin{array}{c}-0.009^{* *} \\
(0.004)\end{array}$ & $\begin{array}{c}-0.013^{* * * *} \\
(0.005)\end{array}$ & $\begin{array}{l}-0.001 \\
(0.005)\end{array}$ & $\begin{array}{c}0.003 \\
(0.005)\end{array}$ & $\begin{array}{l}-0.002 \\
(0.005)\end{array}$ & $\begin{array}{l}-0.001 \\
(0.005)\end{array}$ & $\begin{array}{c}-0.016^{* * *} \\
(0.005)\end{array}$ & $\begin{array}{l}-0.005 \\
(0.006)\end{array}$ & $\begin{array}{l}-0.009 \\
(0.007)\end{array}$ & $\begin{array}{l}-0.002 \\
(0.008)\end{array}$ \\
\hline Partner Variables & $\begin{array}{l}-0.000 \\
(0.002)\end{array}$ & $\begin{array}{c}0.003 \\
(0.002)\end{array}$ & $\begin{array}{c}0.006^{* * * *} \\
(0.002)\end{array}$ & $\begin{array}{c}0.004 \\
(0.002)\end{array}$ & $\begin{array}{c}0.003 \\
(0.003)\end{array}$ & $\begin{array}{c}0.009^{* * *} \\
(0.002)\end{array}$ & $\begin{array}{c}0.004 \\
(0.003)\end{array}$ & $\begin{array}{c}0.012^{* * * *} \\
(0.003)\end{array}$ & $\begin{array}{c}0.007^{* *} \\
(0.003)\end{array}$ & $\begin{array}{c}0.009^{* * * *} \\
(0.003)\end{array}$ & $\begin{array}{c}0.012^{* * * *} \\
(0.004)\end{array}$ \\
\hline Region (East / South) & $\begin{array}{c}0.113 \\
(0.126)\end{array}$ & $\begin{array}{c}0.040 \\
(0.127)\end{array}$ & $\begin{array}{l}-0.040 \\
(0.159)\end{array}$ & $\begin{array}{l}-0.258^{*} \\
(0.151)\end{array}$ & $\begin{array}{l}-0.035 \\
(0.158)\end{array}$ & $\begin{array}{l}-0.070 \\
(0.145)\end{array}$ & $\begin{array}{l}-0.174 \\
(0.149)\end{array}$ & $\begin{array}{c}0.522^{* * * *} \\
(0.149)\end{array}$ & $\begin{array}{c}0.036 \\
(0.159)\end{array}$ & $\begin{array}{c}0.117 \\
(0.156)\end{array}$ & $\begin{array}{c}0.084 \\
(0.252)\end{array}$ \\
\hline Foreign origin & $\begin{array}{c}0.058 \\
(0.079)\end{array}$ & $\begin{array}{c}0.022 \\
(0.069)\end{array}$ & $\begin{array}{c}0.064 \\
(0.074)\end{array}$ & $\begin{array}{l}0.128^{*} \\
(0.077)\end{array}$ & $\begin{array}{l}0.149^{* *} \\
(0.074)\end{array}$ & $\begin{array}{c}0.185^{* * *} \\
(0.066)\end{array}$ & $\begin{array}{c}0.111 \\
(0.075)\end{array}$ & $\begin{array}{c}0.152^{* *} \\
(0.075)\end{array}$ & $\begin{array}{c}0.115 \\
(0.086)\end{array}$ & $\begin{array}{c}0.060 \\
(0.087)\end{array}$ & $\begin{array}{l}0.209^{*} \\
(0.110)\end{array}$ \\
\hline Secondary & $\begin{array}{l}-0.042 \\
(0.132)\end{array}$ & $\begin{array}{l}-0.005 \\
(0.111)\end{array}$ & $\begin{array}{l}-0.081 \\
(0.103)\end{array}$ & $\begin{array}{l}0.151 \\
(0.108)\end{array}$ & $\begin{array}{c}0.049 \\
(0.103)\end{array}$ & $\begin{array}{l}-0.017 \\
(0.094)\end{array}$ & $\begin{array}{l}-0.118 \\
(0.097)\end{array}$ & $\begin{array}{c}0.031 \\
(0.100)\end{array}$ & $\begin{array}{c}0.161 \\
(0.119)\end{array}$ & $\begin{array}{c}0.120 \\
(0.130)\end{array}$ & $\begin{array}{c}0.229 \\
(0.140)\end{array}$ \\
\hline Intermediate & $\begin{array}{l}-0.076 \\
(0.139)\end{array}$ & $\begin{array}{l}-0.066 \\
(0.117)\end{array}$ & $\begin{array}{l}-0.155 \\
(0.110)\end{array}$ & $\begin{array}{c}0.151 \\
(0.114)\end{array}$ & $\begin{array}{l}-0.001 \\
(0.110)\end{array}$ & $\begin{array}{c}0.008 \\
(0.103)\end{array}$ & $\begin{array}{l}-0.109 \\
(0.108)\end{array}$ & $\begin{array}{c}0.020 \\
(0.111)\end{array}$ & $\begin{array}{c}0.064 \\
(0.128)\end{array}$ & $\begin{array}{c}0.122 \\
(0.137)\end{array}$ & $\begin{array}{c}0.227 \\
(0.150)\end{array}$ \\
\hline College & $\begin{array}{l}-0.047 \\
(0.147)\end{array}$ & $\begin{array}{c}0.115 \\
(0.125)\end{array}$ & $\begin{array}{l}-0.101 \\
(0.119)\end{array}$ & $\begin{array}{l}0.078 \\
(0.123)\end{array}$ & $\begin{array}{c}0.069 \\
(0.121)\end{array}$ & $\begin{array}{l}-0.023 \\
(0.113)\end{array}$ & $\begin{array}{l}-0.018 \\
(0.117)\end{array}$ & $\begin{array}{c}0.126 \\
(0.116)\end{array}$ & $\begin{array}{c}0.188 \\
(0.136)\end{array}$ & $\begin{array}{l}0.270^{*} \\
(0.147)\end{array}$ & $\begin{array}{l}0.346^{* *} \\
(0.159)\end{array}$ \\
\hline Farmer & $\begin{array}{l}-0.139 \\
(0.087)\end{array}$ & $\begin{array}{l}-0.126^{*} \\
(0.076)\end{array}$ & $\begin{array}{c}-0.208^{* *} \\
(0.081)\end{array}$ & $\begin{array}{l}-0.081 \\
(0.085)\end{array}$ & $\begin{array}{c}-0.287^{* * * *} \\
(0.087)\end{array}$ & $\begin{array}{c}-0.230^{* * *} \\
(0.085)\end{array}$ & $\begin{array}{c}0.050 \\
(0.087)\end{array}$ & $\begin{array}{c}0.027 \\
(0.092)\end{array}$ & $\begin{array}{c}-0.318^{* * *} \\
(0.102)\end{array}$ & $\begin{array}{c}-0.281^{* *} \\
(0.112)\end{array}$ & $\begin{array}{c}0.072 \\
(0.123)\end{array}$ \\
\hline White-Collor & $\begin{array}{c}0.011 \\
(0.049)\end{array}$ & $\begin{array}{c}0.107^{* *} \\
(0.045)\end{array}$ & $\begin{array}{c}0.013 \\
(0.048)\end{array}$ & $\begin{array}{c}0.043 \\
(0.050)\end{array}$ & $\begin{array}{c}0.043 \\
(0.052)\end{array}$ & $\begin{array}{c}0.038 \\
(0.049)\end{array}$ & $\begin{array}{c}0.064 \\
(0.052)\end{array}$ & $\begin{array}{c}-0.072 \\
(0.051)\end{array}$ & $\begin{array}{l}-0.047 \\
(0.060)\end{array}$ & $\begin{array}{c}0.061 \\
(0.059)\end{array}$ & $\begin{array}{c}0.087 \\
(0.068)\end{array}$ \\
\hline Professional & $\begin{array}{l}0.127^{* *} \\
(0.062)\end{array}$ & $\begin{array}{l}0.108^{*} \\
(0.057)\end{array}$ & $\begin{array}{l}0.122^{* * *} \\
(0.059)\end{array}$ & $\begin{array}{l}0.144^{* *} \\
(0.060)\end{array}$ & $\begin{array}{l}0.118^{*} \\
(0.061)\end{array}$ & $\begin{array}{c}0.209^{* * * *} \\
(0.059)\end{array}$ & $\begin{array}{c}0.233^{* * *} \\
(0.064)\end{array}$ & $\begin{array}{l}0.112^{*} \\
(0.064)\end{array}$ & $\begin{array}{c}0.064 \\
(0.072)\end{array}$ & $\begin{array}{l}0.150^{*} \\
(0.077)\end{array}$ & $\begin{array}{l}0.195^{* *} \\
(0.083)\end{array}$ \\
\hline Self-employed & $\begin{array}{c}0.060 \\
(0.068)\end{array}$ & $\begin{array}{l}-0.010 \\
(0.059)\end{array}$ & $\begin{array}{l}-0.010 \\
(0.063)\end{array}$ & $\begin{array}{l}-0.008 \\
(0.065)\end{array}$ & $\begin{array}{l}0.140^{*} \\
(0.072)\end{array}$ & $\begin{array}{c}0.202^{* * *} \\
(0.066)\end{array}$ & $\begin{array}{c}0.157^{* *} \\
(0.069)\end{array}$ & $\begin{array}{c}0.049 \\
(0.065)\end{array}$ & $\begin{array}{c}0.002 \\
(0.079)\end{array}$ & $\begin{array}{l}0.151^{*} \\
(0.082)\end{array}$ & $\begin{array}{c}0.114 \\
(0.094)\end{array}$ \\
\hline Civil Servant & $\begin{array}{l}-0.031 \\
(0.067)\end{array}$ & $\begin{array}{l}-0.014 \\
(0.060)\end{array}$ & $\begin{array}{l}-0.039 \\
(0.063)\end{array}$ & $\begin{array}{c}0.083 \\
(0.063)\end{array}$ & $\begin{array}{c}0.030 \\
(0.066)\end{array}$ & $\begin{array}{c}0.063 \\
(0.065)\end{array}$ & $\begin{array}{l}-0.001 \\
(0.069)\end{array}$ & $\begin{array}{c}0.010 \\
(0.071)\end{array}$ & $\begin{array}{l}-0.084 \\
(0.079)\end{array}$ & $\begin{array}{c}0.089 \\
(0.083)\end{array}$ & $\begin{array}{c}0.019 \\
(0.089)\end{array}$ \\
\hline City & $\begin{array}{l}-0.016 \\
(0.037)\end{array}$ & $\begin{array}{l}-0.041 \\
(0.035)\end{array}$ & $\begin{array}{c}0.009 \\
(0.036)\end{array}$ & $\begin{array}{c}0.028 \\
(0.037)\end{array}$ & $\begin{array}{c}0.019 \\
(0.040)\end{array}$ & $\begin{array}{c}0.052 \\
(0.038)\end{array}$ & $\begin{array}{c}0.038 \\
(0.041)\end{array}$ & $\begin{array}{c}0.012 \\
(0.040)\end{array}$ & $\begin{array}{l}0.113^{* *} \\
(0.047)\end{array}$ & $\begin{array}{c}0.035 \\
(0.047)\end{array}$ & $\begin{array}{l}-0.025 \\
(0.053)\end{array}$ \\
\hline Large City & $\begin{array}{c}0.002 \\
(0.049)\end{array}$ & $\begin{array}{c}0.001 \\
(0.046)\end{array}$ & $\begin{array}{l}-0.063 \\
(0.048)\end{array}$ & $\begin{array}{c}0.067 \\
(0.048)\end{array}$ & $\begin{array}{l}0.093^{*} \\
(0.049)\end{array}$ & $\begin{array}{c}0.126^{* * * *} \\
(0.048)\end{array}$ & $\begin{array}{c}0.047 \\
(0.051)\end{array}$ & $\begin{array}{c}0.119^{* *} \\
(0.054)\end{array}$ & $\begin{array}{c}0.211^{* * *} \\
(0.061)\end{array}$ & $\begin{array}{l}0.107^{*} \\
(0.063)\end{array}$ & $\begin{array}{c}0.057 \\
(0.071)\end{array}$ \\
\hline birth & $\begin{array}{c}0.003 \\
(0.005)\end{array}$ & $\begin{array}{l}-0.001 \\
(0.004)\end{array}$ & $\begin{array}{c}0.003 \\
(0.005)\end{array}$ & $\begin{array}{l}-0.005 \\
(0.005)\end{array}$ & $\begin{array}{l}-0.010^{*} \\
(0.005)\end{array}$ & $\begin{array}{c}-0.010^{* *} \\
(0.005)\end{array}$ & $\begin{array}{l}-0.009^{*} \\
(0.005)\end{array}$ & $\begin{array}{l}-0.003 \\
(0.005)\end{array}$ & $\begin{array}{l}-0.001 \\
(0.006)\end{array}$ & $\begin{array}{l}-0.004 \\
(0.007)\end{array}$ & $\begin{array}{c}0.001 \\
(0.008)\end{array}$ \\
\hline height & $\begin{array}{l}0.005^{*} \\
(0.002)\end{array}$ & $\begin{array}{c}0.003 \\
(0.002)\end{array}$ & $\begin{array}{l}0.005^{* *} \\
(0.002)\end{array}$ & $\begin{array}{l}0.004^{*} \\
(0.002)\end{array}$ & $\begin{array}{l}-0.000 \\
(0.003)\end{array}$ & $\begin{array}{c}0.002 \\
(0.003)\end{array}$ & $\begin{array}{l}-0.003 \\
(0.003)\end{array}$ & $\begin{array}{c}0.001 \\
(0.003)\end{array}$ & $\begin{array}{c}0.004 \\
(0.003)\end{array}$ & $\begin{array}{l}0.005^{*} \\
(0.003)\end{array}$ & $\begin{array}{c}0.004 \\
(0.003)\end{array}$ \\
\hline Experience & $\begin{array}{l}-0.048^{*} \\
(0.025)\end{array}$ & $\begin{array}{l}-0.031 \\
(0.024)\end{array}$ & $\begin{array}{l}-0.011 \\
(0.025)\end{array}$ & $\begin{array}{c}0.002 \\
(0.026)\end{array}$ & $\begin{array}{c}0.006 \\
(0.029)\end{array}$ & $\begin{array}{l}-0.023 \\
(0.028)\end{array}$ & $\begin{array}{c}0.004 \\
(0.030)\end{array}$ & $\begin{array}{c}0.023 \\
(0.031)\end{array}$ & $\begin{array}{l}-0.018 \\
(0.036)\end{array}$ & $\begin{array}{l}0.065^{*} \\
(0.038)\end{array}$ & $\begin{array}{c}0.051 \\
(0.044)\end{array}$ \\
\hline Sq experience & $\begin{array}{l}-0.028^{*} \\
(0.016)\end{array}$ & $\begin{array}{l}-0.008 \\
(0.015)\end{array}$ & $\begin{array}{c}0.007 \\
(0.015)\end{array}$ & $\begin{array}{l}0.021 \\
(0.016)\end{array}$ & $\begin{array}{c}0.023 \\
(0.018)\end{array}$ & $\begin{array}{c}0.005 \\
(0.017)\end{array}$ & $\begin{array}{l}-0.006 \\
(0.018)\end{array}$ & $\begin{array}{l}-0.030 \\
(0.019)\end{array}$ & $\begin{array}{l}-0.032 \\
(0.021)\end{array}$ & $\begin{array}{l}-0.020 \\
(0.022)\end{array}$ & $\begin{array}{l}-0.038 \\
(0.025)\end{array}$ \\
\hline weekly hours & $\begin{array}{c}0.001 \\
(0.002)\end{array}$ & $\begin{array}{c}0.002 \\
(0.002)\end{array}$ & $\begin{array}{l}0.003^{*} \\
(0.002)\end{array}$ & $\begin{array}{l}-0.001 \\
(0.002)\end{array}$ & $\begin{array}{l}-0.000 \\
(0.002)\end{array}$ & $\begin{array}{l}-0.002 \\
(0.002)\end{array}$ & $\begin{array}{c}-0.004^{* *} \\
(0.002)\end{array}$ & $\begin{array}{c}0.001 \\
(0.002)\end{array}$ & $\begin{array}{c}0.003 \\
(0.002)\end{array}$ & $\begin{array}{c}0.002 \\
(0.002)\end{array}$ & $\begin{array}{l}-0.002 \\
(0.003)\end{array}$ \\
\hline education & $\begin{array}{c}0.029 * * * \\
(0.008)\end{array}$ & $\begin{array}{c}0.028^{* * *} \\
(0.007)\end{array}$ & $\begin{array}{c}0.041^{* * * *} \\
(0.008)\end{array}$ & $\begin{array}{c}0.053^{* * *} \\
(0.008)\end{array}$ & $\begin{array}{c}0.063^{* * *} \\
(0.009)\end{array}$ & $\begin{array}{c}0.043^{* * *} \\
(0.008)\end{array}$ & $\begin{array}{c}0.054^{* * *} \\
(0.009)\end{array}$ & $\begin{array}{c}0.068^{* * *} \\
(0.009)\end{array}$ & $\begin{array}{c}0.065^{* * *} \\
(0.010)\end{array}$ & $\begin{array}{c}0.056^{* * *} \\
(0.011)\end{array}$ & $\begin{array}{c}0.069 * * * \\
(0.012)\end{array}$ \\
\hline Energy and Minig & $\begin{array}{c}0.145^{* *} \\
(0.068)\end{array}$ & $\begin{array}{l}0.115^{*} \\
(0.062)\end{array}$ & $\begin{array}{c}0.059 \\
(0.066)\end{array}$ & $\begin{array}{l}-0.037 \\
(0.066)\end{array}$ & $\begin{array}{l}-0.128^{*} \\
(0.072)\end{array}$ & $\begin{array}{c}-0.197^{* * *} \\
(0.068)\end{array}$ & $\begin{array}{c}-0.247^{* * *} \\
(0.076)\end{array}$ & $\begin{array}{c}-0.183^{* *} \\
(0.075)\end{array}$ & $\begin{array}{c}-0.344^{* * *} \\
(0.085)\end{array}$ & $\begin{array}{c}-0.199^{* * *} \\
(0.084)\end{array}$ & $\begin{array}{c}-0.206^{* *} \\
(0.095)\end{array}$ \\
\hline Engineering & $\begin{array}{c}0.115 \\
(0.079)\end{array}$ & $\begin{array}{c}0.045 \\
(0.072)\end{array}$ & $\begin{array}{l}-0.044 \\
(0.075)\end{array}$ & $\begin{array}{l}0.160^{* * *} \\
(0.081)\end{array}$ & $\begin{array}{l}-0.010 \\
(0.085)\end{array}$ & $\begin{array}{c}-0.313^{* * *} \\
(0.087)\end{array}$ & $\begin{array}{c}-0.285^{* * *} \\
(0.090)\end{array}$ & $\begin{array}{l}-0.015 \\
(0.084)\end{array}$ & $\begin{array}{c}0.049 \\
(0.097)\end{array}$ & $\begin{array}{l}-0.057 \\
(0.099)\end{array}$ & $\begin{array}{l}-0.051 \\
(0.110)\end{array}$ \\
\hline Manufacturing & $\begin{array}{c}-0.215^{* * * *} \\
(0.080)\end{array}$ & $\begin{array}{l}-0.109 \\
(0.076)\end{array}$ & $\begin{array}{l}-0.011 \\
(0.082)\end{array}$ & $\begin{array}{l}-0.137^{*} \\
(0.081)\end{array}$ & $\begin{array}{c}-0.224^{* *} \\
(0.089)\end{array}$ & $\begin{array}{l}-0.142 \\
(0.094)\end{array}$ & $\begin{array}{l}-0.178^{*} \\
(0.098)\end{array}$ & $\begin{array}{c}-0.356^{* * * *} \\
(0.100)\end{array}$ & $\begin{array}{c}-0.298^{* *} \\
(0.117)\end{array}$ & $\begin{array}{c}-0.254^{* *} \\
(0.111)\end{array}$ & $\begin{array}{l}-0.186 \\
(0.116)\end{array}$ \\
\hline Construction & $\begin{array}{c}0.042 \\
(0.074)\end{array}$ & $\begin{array}{l}-0.012 \\
(0.070)\end{array}$ & $\begin{array}{l}-0.118 \\
(0.077)\end{array}$ & $\begin{array}{l}-0.022 \\
(0.079)\end{array}$ & $\begin{array}{c}-0.228^{* * *} \\
(0.087)\end{array}$ & $\begin{array}{c}-0.221^{* * *} \\
(0.083)\end{array}$ & $\begin{array}{c}-0.511^{* * *} \\
(0.086)\end{array}$ & $\begin{array}{c}-0.266^{* * * *} \\
(0.086)\end{array}$ & $\begin{array}{c}-0.301^{* * *} \\
(0.096)\end{array}$ & $\begin{array}{c}-0.261^{* * * *} \\
(0.097)\end{array}$ & $\begin{array}{c}-0.243^{* *} \\
(0.109)\end{array}$ \\
\hline Sales & $\begin{array}{l}-0.056 \\
(0.064)\end{array}$ & $\begin{array}{c}0.021 \\
(0.059)\end{array}$ & $\begin{array}{c}0.007 \\
(0.062)\end{array}$ & $\begin{array}{l}-0.059 \\
(0.064)\end{array}$ & $\begin{array}{l}-0.090 \\
(0.066)\end{array}$ & $\begin{array}{c}-0.141^{* *} \\
(0.066)\end{array}$ & $\begin{array}{c}-0.220^{* * *} \\
(0.071)\end{array}$ & $\begin{array}{l}-0.097 \\
(0.069)\end{array}$ & $\begin{array}{l}-0.120 \\
(0.082)\end{array}$ & $\begin{array}{l}-0.130 \\
(0.083)\end{array}$ & $\begin{array}{l}-0.130 \\
(0.091)\end{array}$ \\
\hline Transport & $\begin{array}{c}0.023 \\
(0.086)\end{array}$ & $\begin{array}{c}0.066 \\
(0.076)\end{array}$ & $\begin{array}{c}0.104 \\
(0.081)\end{array}$ & $\begin{array}{l}0.037 \\
(0.082)\end{array}$ & $\begin{array}{l}-0.027 \\
(0.088)\end{array}$ & $\begin{array}{c}-0.244^{* * *} \\
(0.092)\end{array}$ & $\begin{array}{c}-0.440^{* * *} \\
(0.099)\end{array}$ & $\begin{array}{l}-0.066 \\
(0.096)\end{array}$ & $\begin{array}{c}-0.456^{* * *} \\
(0.115)\end{array}$ & $\begin{array}{l}-0.048 \\
(0.121)\end{array}$ & $\begin{array}{c}0.149 \\
(0.163)\end{array}$ \\
\hline Financial & $\begin{array}{c}0.125 \\
(0.107)\end{array}$ & $\begin{array}{l}0.260^{* *} \\
(0.102)\end{array}$ & $\begin{array}{c}0.367^{* * * *} \\
(0.108)\end{array}$ & $\begin{array}{c}0.300^{* * * *} \\
(0.112)\end{array}$ & $\begin{array}{l}0.213^{*} \\
(0.118)\end{array}$ & $\begin{array}{l}-0.104 \\
(0.105)\end{array}$ & $\begin{array}{c}0.122 \\
(0.115)\end{array}$ & $\begin{array}{c}0.104 \\
(0.116)\end{array}$ & $\begin{array}{c}0.034 \\
(0.125)\end{array}$ & $\begin{array}{c}0.029 \\
(0.128)\end{array}$ & $\begin{array}{c}0.058 \\
(0.133)\end{array}$ \\
\hline Service & $\begin{array}{c}0.072 \\
(0.065)\end{array}$ & $\begin{array}{c}0.119^{* *} \\
(0.059)\end{array}$ & $\begin{array}{c}0.193^{* * * *} \\
(0.063)\end{array}$ & $\begin{array}{c}0.094 \\
(0.063)\end{array}$ & $\begin{array}{l}-0.036 \\
(0.069)\end{array}$ & $\begin{array}{l}-0.075 \\
(0.066)\end{array}$ & $\begin{array}{l}-0.085 \\
(0.072)\end{array}$ & $\begin{array}{c}0.021 \\
(0.070)\end{array}$ & $\begin{array}{l}-0.055 \\
(0.080)\end{array}$ & $\begin{array}{c}-0.159^{* *} \\
(0.081)\end{array}$ & $\begin{array}{c}-0.198^{* *} \\
(0.088)\end{array}$ \\
\hline Education & $\begin{array}{c}0.092 \\
(0.079)\end{array}$ & $\begin{array}{c}0.164^{* *} \\
(0.069)\end{array}$ & $\begin{array}{l}0.123^{*} \\
(0.072)\end{array}$ & $\begin{array}{l}-0.036 \\
(0.073)\end{array}$ & $\begin{array}{l}-0.096 \\
(0.077)\end{array}$ & $\begin{array}{l}-0.064 \\
(0.075)\end{array}$ & $\begin{array}{l}-0.062 \\
(0.083)\end{array}$ & $\begin{array}{c}-0.200^{* *} \\
(0.081)\end{array}$ & $\begin{array}{c}0.047 \\
(0.094)\end{array}$ & $\begin{array}{c}0.049 \\
(0.094)\end{array}$ & $\begin{array}{c}0.087 \\
(0.101)\end{array}$ \\
\hline Health & $\begin{array}{l}-0.003 \\
(0.069)\end{array}$ & $\begin{array}{c}0.055 \\
(0.062)\end{array}$ & $\begin{array}{c}0.016 \\
(0.066)\end{array}$ & $\begin{array}{l}-0.026 \\
(0.068)\end{array}$ & $\begin{array}{l}-0.027 \\
(0.072)\end{array}$ & $\begin{array}{c}-0.182^{* * *} \\
(0.070)\end{array}$ & $\begin{array}{c}-0.286^{* * *} \\
(0.075)\end{array}$ & $\begin{array}{l}-0.096 \\
(0.075)\end{array}$ & $\begin{array}{l}-0.100 \\
(0.086)\end{array}$ & $\begin{array}{l}-0.051 \\
(0.087)\end{array}$ & $\begin{array}{l}-0.036 \\
(0.096)\end{array}$ \\
\hline Income & $\begin{array}{c}-0.273^{* * * *} \\
(0.027)\end{array}$ & $\begin{array}{c}-0.265^{* * * *} \\
(0.026)\end{array}$ & $\begin{array}{c}-0.315^{* * * *} \\
(0.026)\end{array}$ & $\begin{array}{c}-0.265^{* * * *} \\
(0.027)\end{array}$ & $\begin{array}{c}-0.328^{* * * *} \\
(0.028)\end{array}$ & $\begin{array}{c}-0.283^{* * *} \\
(0.027)\end{array}$ & $\begin{array}{c}-0.284^{* * *} \\
(0.029)\end{array}$ & $\begin{array}{c}-0.294^{* * *} \\
(0.032)\end{array}$ & $\begin{array}{c}-0.325^{* * *} \\
(0.034)\end{array}$ & $\begin{array}{c}-0.393^{* * *} \\
(0.038)\end{array}$ & $\begin{array}{c}-0.333^{* * *} \\
(0.041)\end{array}$ \\
\hline Constant & $26.376^{* * * *}$ & $30.593^{* * *}$ & $29.515^{* * * *}$ & $22.869^{* * *}$ & $26.059^{* * * *}$ & $33.556^{* * *}$ & $31.455^{* * *}$ & $46.839^{* * * *}$ & $22.506^{\text {**** }}$ & $36.387^{* * * *}$ & 11.315 \\
\hline & -4.898 & -4.568 & -4.880 & -5.209 & -5.899 & -5.676 & -6.024 & -6.006 & -6.977 & -7.053 & $(8.315)$ \\
\hline Observations & 2,136 & 2,361 & 2,273 & 2,148 & 1,891 & 1,959 & 1,825 & 1,607 & 1,413 & 1,239 & 970 \\
\hline R-squared & 0.436 & 0.428 & 0.418 & 0.416 & 0.441 & 0.437 & 0.472 & 0.484 & 0.440 & 0.470 & 0.458 \\
\hline
\end{tabular}

